Old Dominion University

ODU Digital Commons

Theses and Dissertations in Business

Administration

College of Business (Strome)

Summer 2008

\title{
How Personal Nostalgia Influences Giving to Charity
}

Altaf Merchant

Old Dominion University

Follow this and additional works at: https://digitalcommons.odu.edu/businessadministration_etds

Part of the Marketing Commons

\section{Recommended Citation}

Merchant, Altaf. "How Personal Nostalgia Influences Giving to Charity" (2008). Doctor of Philosophy (PhD), Dissertation, , Old Dominion University, DOI: 10.25777/0tq7-rt72

https://digitalcommons.odu.edu/businessadministration_etds/38

This Dissertation is brought to you for free and open access by the College of Business (Strome) at ODU Digital Commons. It has been accepted for inclusion in Theses and Dissertations in Business Administration by an authorized administrator of ODU Digital Commons. For more information, please contact digitalcommons@odu.edu. 


\title{
HOW PERSONAL NOSTALGIA INFLUENCES
}

\section{GIVING TO CHARITY}

\author{
by \\ Altaf Merchant \\ M.M.S. May 1997, University of Mumbai, India \\ A Dissertation Submitted to the Faculty \\ of Old Dominion University in Partial Fulfillment of the \\ Requirements for the Degree of \\ DOCTOR OF PHILOSOPHY \\ BUSINESS ADMINISTRATION \\ OLD DOMINION UNIVERSITY \\ August 2008
}

Approved by:

Johh Ford (Chair)

Fdwrard Markenxeki

Leona Tant

Adrian Sargeant 


\section{ABSTRACT \\ HOW PERSONAL NOSTALGIA INFLUENCES GIVING TO CHARITY \\ Altaf Merchant \\ Old Dominion University, 2008 \\ Director: Dr. John B. Ford}

Charitable organizations in the U.S. have found it increasingly difficult to raise funds from donors. With a decline in the number of donors and with the number of charitable organizations increasing, there is a greater need than ever to engage the giver and encourage him/her to increase their giving to charitable organizations. NPOs (notfor-profit organizations) can facilitate this engagement through the identification of emotional constructs that can drive donor commitment to the NPO and increase charitable giving. In a recent study, Sargeant et al. (2006) have shown that charities which engage the giver emotionally are able to create stronger commitment from the giver. One such emotionally engaging construct is personal nostalgia. Personal nostalgia is a longing for a past which has been personally experienced by the individual. Personal nostalgia evokes warmth and joy arising out of remembering the past but there is also a sense of loss that the past is no more. The author has not found any study that has linked personal nostalgia to giving to charity. This research links personal nostalgia to charitable giving. From an academic standpoint it adds to the literature in the areas of personal nostalgia and not for profit marketing. From a Managerial standpoint, NPOs could benefit by identifying significant personal experiences of the donor and evoke personal nostalgia in their fundraising appeals. This research presents a theoretical model and ten research hypotheses. It shows that age, discontinuity, loneliness, past experiences and recovery 
from grief positively influence the donor's personal nostalgia. Personal nostalgia in turn provides emotional utility and familial utility to the donor. These in turn strengthen the commitment of the donor to the charitable organization which facilitates charitable giving. Data were collected from 502 U.S. charitable donors. Structural equation modeling was utilized and tests were carried out to ascertain the significance of the hypothesized relationships. The study found support for nine out of the ten hypothesized relationships. It is argued that this study would be relevant to those NPOs which can evoke personal nostalgia among their donors. Some examples would include alumni associations of academic institutions, hospitals, etc. 
I dedicate my dissertation to my parents - Amina and Gulamali Merchant. 


\section{ACKNOWLEDGEMENTS}

This dissertation is a culmination of an exciting journey and the start of a new one. This journey has been challenging, interesting and extremely productive. Like any journey there is a satisfaction that it has been completed successfully but there is also the nostalgia of the fun had along the way. I would at first like to thank God for giving me strength and wisdom, and for holding my hand through this journey. I could not have completed this without the help and sacrifice of the many people who have supported me and made me achieve my dream.

At first I would like to thank my parents. Their encouragement, blessings and sacrifice have been a major contribution in my life. I dedicate my dissertation to them. My wife, Zahra and son Zaafir have stood by me through the last three years, supported and motivated me to believe in myself. Thank you for your love and affection and for being the "wind beneath my wings". I also acknowledge the emotional support and friendship of my sister Yasmin. She has always been a source of motivation.

From the time I joined the doctoral program, Dr. John Ford was my coach, mentor, teacher and close friend. For his vision, his inspiration and his guidance I am grateful to him. I am thankful to him for giving me the opportunity to co-author with him in high quality research projects, for giving me the opportunity to review scholarly articles and for being the pillar of my dissertation by agreeing to being its Chair. I would also like to thank the other members of my dissertation committee - Dr. Edward Markowski and Dr. Leona Tam for their valuable inputs and help at each stage of my research and for agreeing to co-author with me on research papers. I would like to acknowledge and thank the insightful involvement of Dr. Adrian Sargeant (Indiana 
University Purdue University) who took time off his schedule and actively participated as an external member of my dissertation committee. I am also grateful to him for giving me the opportunity to review scholarly journal articles and for agreeing to co-author with me on research projects.

I would like to convey my gratitude to all my teachers, who have taught me how to research and think critically. I would like to thank Dr. Kiran Karande for helping me build a solid methodology foundation and co-authoring with me on research projects. Dr. Mahesh Gopinath for stimulating my appetite for consumer behavior and being my coauthor; Dr. Shaomin Li, Dr. John Doukas and Dr. Deepak Sethi for creating an appreciation for International Business and Dr. Steve Rhiel for his insights on research methods. I would like to also thank Dr. Anusorn Singhapakdi for his advice, help and giving me the opportunity to teach a variety of courses. I would like to acknowledge the friendship of Dr. Anil Nair. I would like to thank all the marketing faculty members and my well wishers for nominating me for awards, scholarships and fellowships. I am humbled by their kindness and their appreciation.

I am grateful to Dean Nancy Bagranoff for allocating funds for my research projects, funding my travel to conferences and for giving me the opportunity for consulting assignments. I am also grateful to Dr. Sylvia Hudgins for her encouragement and for giving me the opportunity to serve on the Dean's Student Advisory Committee and Dr. Ali Ardalan for his kind support. I am thankful to Katrina Davenport for her kindness and not only helping me promptly but also for being my close friend. I would like to thank Kathy Heins for all the administrative help she provided and Connie Merriman for being my well wisher. I am grateful to Dr. Theresa Kirchner for being my 
friend, well wisher and co-author. I am also grateful to my colleagues in the doctoral program - Dr. Rebecca Hochraedel, Kunal Sethi and Rahnuma Ahsan, for their help and friendship. 


\section{TABLE OF CONTENTS}

Page

LIST OF TABLES.............................................................

LIST OF FIGURES..........................................................

Chapter

I. STATEMENT OF PROBLEM...........................................

WHY PEOPLE GIVE TO CHARITY? .................................

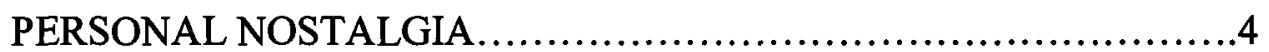

PURPOSE OF RESEARCH.........................................6

CONTRIBUTION .................................................... 7

ORGANIZATION OF THIS DISSERTATION...........................8

II. REVIEW OF THE LITERATURE.....................................9

INTRODUCTION.................................................9

GIVING BEHAVIOR................................................ 9

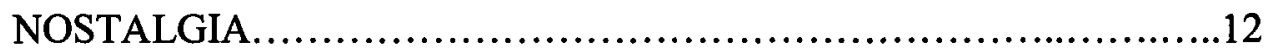

PERSONAL NOSTALGIA EXPERIENCE...........................21

FACTORS INFLUENCING PERSONAL NOSTALGIA................24

PROPOSED CONCEPTUAL MODEL AND RESEARCH

HYPOTHESES ......................................................29

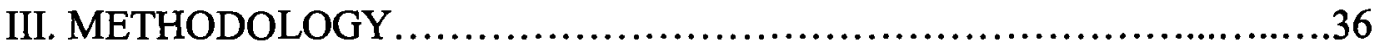

INTRODUCTION ........................................................

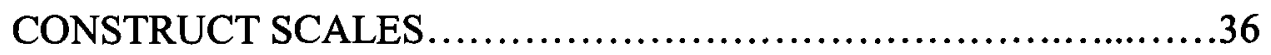

RESEARCH PROCESS...........................................46

IV. RESULTS OF THE STUDY .........................................50

INTRODUCTION....................................................50

DATA COLLECTION..............................................50

DATA ANALYSIS...............................................55

V. CONCLUSIONS AND RECOMMENDATIONS...........................70 


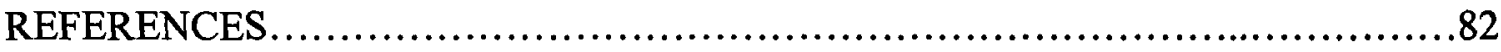
APPENDIXES

A. QUESTIONNAIRE.

B. LIST OF DELETED SCALE ITEMS.

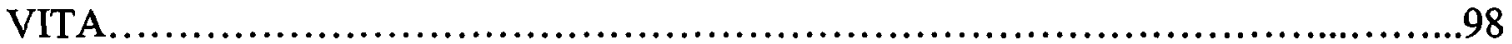




\section{LIST OF TABLES}

Table

Page

2-1 Types of Nostalgia .................................................... 16

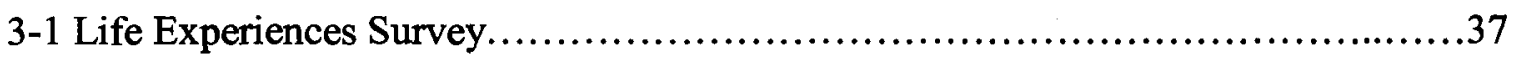

3-2 Measure of the presence of a significant life experience associated

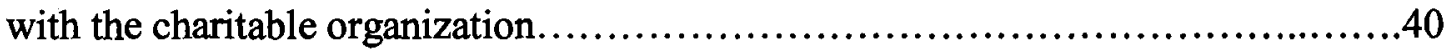

3-3 Revised UCLA Loneliness Scale.......................................41

3-4 Measure for Recovery from Grief.......................................42

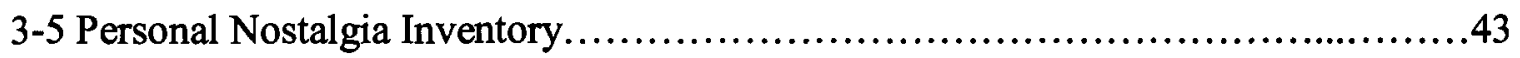

3-6 Scale for EU and FU..................................................

3-7 Commitment scale.....................................................45

3-8 Intention to donate scale.................................................46

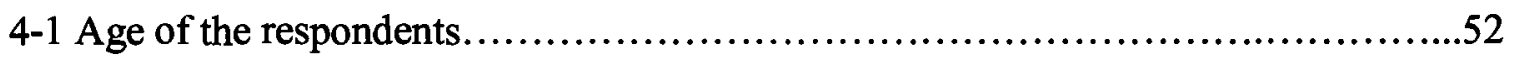

4-2 Annual household income of the Respondents...............................53

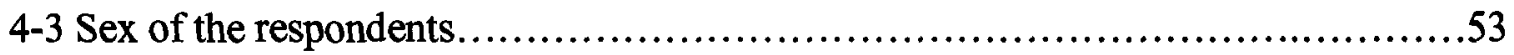

4-4 Racial background of the respondents....................................53

4-5 Education level of the respondents......................................5

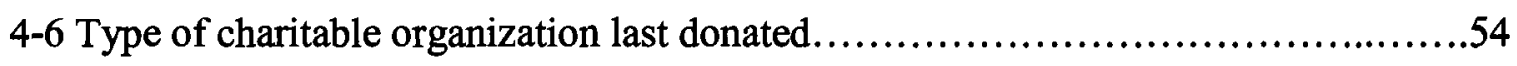

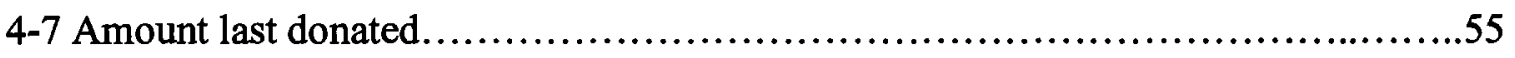

4-8 How many times ever donated to the charitable organization.....................55

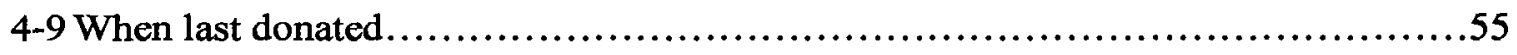

4-10 Confirmatory factor analysis of constructs...................................59

4-11 Correlations among latent constructs...................................65

4-12 Structural Model Results and Hypotheses tests...............................65 
4-13 Variance Explained of Endogenous Constructs.............................66

4-14 Structural Model Results and Hypotheses tests

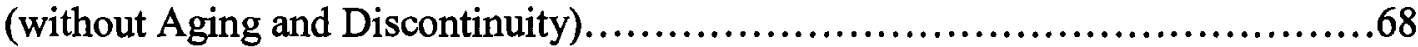

4-15 Variance Explained of Endogenous Constructs

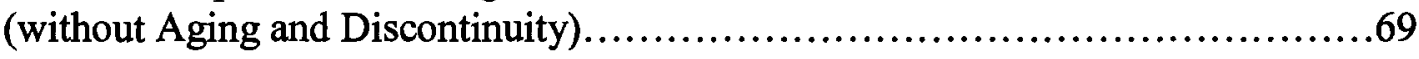

5-1 ANOVA among infrequent donors.........................................79 


\section{LIST OF FIGURES}

Figure

1-1 Conceptual Model.............................................................6

2-1 Conceptual Model........................................................30

4-1 Structural Model: Results................................................61

5-1 Example of Nostalgic Appeal............................................ 72

5-2 Generating Negative Emotions...............................................78 


\section{CHAPTER 1: STATEMENT OF THE PROBLEM}

\section{INTRODUCTION}

Philanthropic institutions in the U.S. have found it increasingly difficult to raise needed funds from givers (Eikenberry, 2005). In fact this has been seen in other countries as well. Over the past 10 years charities in the U.K. have also been finding it increasingly difficult to raise funds (Sargeant et al., 2000). There are a number of reasons for this. First of all, there is a decline in the number of donors in the U.S.. As per the Index of National Fundraising Performance of the Target Analysis Group (Association of Fundraising Professionals, 2007) the number of donors has declined by $1.3 \%$ in 2006 over 2005 and by $1.7 \%$ in the first half of 2007 over 2006. This implies that NPOs would have to work harder to increase per donor contributions to make up for the decline in the number of givers. Secondly, many current givers only give small amounts to charities. It has been shown that individuals give less than $2 \%$ of their personal income to charities (Burke, 2001). Thirdly, there has been an increase in the number of charitable organizations (Sargeant et al., 2000), which raises the competitive intensity across a larger number of organizations fighting for a share of a limited pool of donor funds. The picture is not a promising one.

The key challenge for Marketing Managers of not-for-profit organizations (NPOs) is to increase the amount of giving among current givers and to attract new and younger givers. To achieve this, NPOs are urged to engage their givers with appeals that interest and involve them. They can facilitate this engagement through the identification of emotional constructs that can drive commitment and increase charitable giving. Recently, Sargeant et al. (2006) proposed a perceptual model of donor giving behavior 
which showed significant linkages between such perceptual dimensions as emotional utility (giving to feel better about oneself), familial utility (giving connected to a family member affected by the cause associated with the charity) and commitment which in turn was found to drive donor giving. While this study took a major step in the right direction, the authors noted that additional research into other driving perceptual constructs is warranted.

One such potentially relevant affecting construct is nostalgia. Academic work involving nostalgia has shown it to evoke a variety of emotions (Davis, 1979; Gardener, 1985). It evokes a poignant mixture of mental pain and joy (Freud, 1926; Akhtar, 1996). The American Heritage Dictionary (1972) defines nostalgia as a "longing for things, persons or situations that are not present." It is basically a longing for a perceived utopian past (Bassin, 1993, Batcho; 1998) without the actual acceptance that it is over (Kaplan, 1987). Nostalgia has been found to affect old and young alike (McCann, 1941), and it appears to be not only a longing for a past which has been personally experienced, but it also represents a longing for a "lost past paradise" (Peters, 1985) which one has possibly never experienced (Stern, 1992). There is an increasing use of nostalgia in the marketing of consumer goods (Baker and Kennedy, 1994). There is an attempt to "reenact the reunion" with the lost past with appeals of "vintage retro" (Bassin, 1993), traditions, rituals and the ideal American community. One can easily see these attempts in the use of the songs of the 1960s and 1970s and the strong emotional connections made between the past and such products as automobiles, hamburgers and soft drinks. What might the connection be between nostalgia and charitable giving behavior? Sargeant et al. (2006) suggest that familial utility may actually be affected by nostalgia 
since desire for the situation experienced or perceived to have been experienced when a loved one was still alive may influence giving in memory of that loved one. However, we are not aware of any research that has been done to understand the relationship between the experience of nostalgia and charitable giving and the factors that influence this relationship.

\section{WHY DO PEOPLE GIVE TO CHARITY?}

All motives for giving are not altruistic. Giving may result in a direct gain to the giver. Examples of pure altruistic motives would include a warm glow (Andreoni, 1990), a desire to cause social change (Radley and Kennedy, 1995), empathy, sympathy, fear, guilt, pity (Feldman, 1985; Fultz et al., 1986) and a pure belief in the cause (Webber, 2004). The non-altruistic motives would be either emotional or economic. Emotional benefits would include prestige and respect in the community (Olson, 1965), self-esteem (Mathur, 1996), recognition (Kottasz, 2004), peer pressure (Webber, 2004) and the alleviation of negative feelings (Cialdini, 1987). Economic benefits would include such things as tax benefits and invitations to gala events (Kottasz, 2004; Sargeant et al., 2006). Sargeant et al. (2006) summarized the intrinsic determinants of giving under three categories: familial utility (benefits to family members either alive or in memoriam), emotional utility (emotions felt) and demonstrable utility (a direct economic benefit accruing to the giver like the chance to attend a performance, dinner, event etc). Those who are committed to the NPO are more likely to give to the NPO. The higher the emotional utility (emotions felt out of giving) and familial utility (link to family), the greater the degree of commitment and the greater the level of giving that would be exhibited by the donor to that charitable organization (Sargeant et al., 2006). The 
perceived demonstrable benefits (selfish gains like invitations to gala events (Kottasz, 2004)) associated with charitable giving helps to persuade non-donors to become donors. However, it does not impact commitment nor does it impact trust in the charitable organization (Sargeant et al., 2006).

\section{PERSONAL NOSTALGIA}

Holbrook (1993) defines nostalgia as "A longing for the past or a fondness for possessions and activities associated with the days of the past" (page 245). It is the remembering of the past. There are two types of nostalgia - vicarious nostalgia and personal nostalgia. While vicarious nostalgia refers to the longing for a past not personally experienced by the individual, personal nostalgia refers to the longing for the past that has been personally experienced by the individual. Since baby boomers are aging, they are becoming increasingly nostalgic (Unger et al., 1991) and as a result there is an increasing use of nostalgia in the marketing of consumer goods. There is an attempt to "reenact the reunion" with the lost past (Bassin, 1993), traditions, rituals and the ideal American community (Daniels, 1985). One can easily see these attempts in the use of the songs of the 1960s and 1970s and the strong emotional connections made between the past and such products as automobiles, hamburgers and soft drinks. Since it is evident that connecting with the past through personal nostalgia is effective and relevant, this study shall focus on the relationship between personal nostalgia and charitable giving. The personal nostalgia experience involves remembering the memories of the days gone in the form of images which lead to a variety of emotions. There is the warmth and the joy arising out of remembering the past but there is also a sense of loss that the past is no. more (Holak and Havlena, 1998). It is a bittersweet experience. Some people are more 
prone or have a higher propensity to be nostalgic than others. This depends on various factors including their biological make up. People who are more nostalgia prone are more likely to be stirred by nostalgic communications (Batcho, 1998). Some of the factors that influence personal nostalgia are as follows:

1) Discontinuity: Those that face discontinuous life experiences tend to get more nostalgic and look to the past for a sense of stability (Mehta and Belk, 1991).The person takes comfort in the memories and the emotions of the days gone by (Ornstein and Ornstein, 1985).

2) Past experiences: Significant life experiences are better recalled. Hence, people feel nostalgic for more significant past experiences than less significant past experiences (Baumgartner, 1992).

3) Loneliness: When people feel lonely they tend to get nostalgic as the past acts as a "coat of comfort" (Lomsky-Feder and Rapoport, 2000). By indulging in personal nostalgia they remember the past events with friends and family, and relive the times which were happier.

4) Aging: As people age they get more nostalgic (Davis, 1979). They tend to long for the days gone by and want to relive the past.

5) Recovery from grief by continual involvement with deceased: In some cases the grief that an individual feels and tries to cope with also influences the personal nostalgia that he or she may experience. The person copes with grief by developing continual bonds with the deceased person by remembering the past (Bonnano and Kaltman, 1999). 


\section{PURPOSE OF THIS RESEARCH}

This research links personal nostalgia to charitable giving. It presents a conceptual model (see figure 1-1) and proposes ten hypotheses. This research argues that age, discontinuity, loneliness, past experiences and recovery from grief all influence personal nostalgia that a donor may experience. Personal nostalgia in turn will provide emotional utility and familial utility to the donor. These in turn will strengthen the commitment of the donor to the charitable organization which would lead to charitable giving by the donor. Does this mean that this is relevant to all NPOs? It is argued that this would be relevant to those NPOs which are able to evoke personal nostalgia among their donors. Organizations with which donors share emotional memories of the past are likely to evoke personal nostalgia. Some examples would include alumni associations of academic institutions, hospitals, and the American Cancer Association.

Figure 1-1 - Conceptual Model

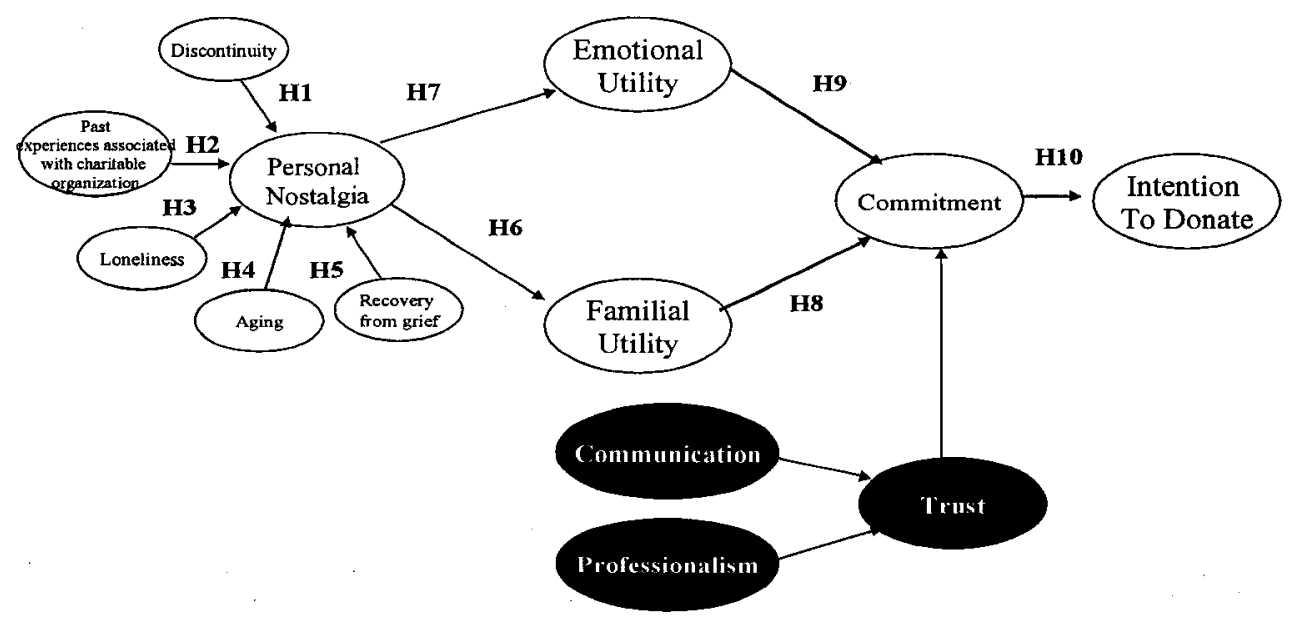

(Adapted from Sargeant et al, 2006) 


\section{CONTRIBUTION}

\section{Theoretical contribution}

This research has several important theoretical contributions. Firstly, the author has not found any research which has examined the relationship between personal nostalgia and charitable giving. By exploring this linkage in detail the author fills a crucial gap in the literature. Secondly, the author has also not found any study that has comprehensively looked at the role of the potential factors that influence nostalgia, and in particular the context of charitable giving would be a new and relevant dimension. Thirdly, this research studies the relationship of recovery from grief and nostalgia. Though other researches have looked at this construct, how it relates to nostalgia and its potential influence on giving to charity is an area which has also not yet been studied by other researches in this area.

\section{Managerial Implications}

NPOs that give the donor a window to experience personal nostalgia are likely to benefit through the creation of stronger bonds with current donors and by attracting nongivers. The NPO Marketing Manager would be able to develop communications that could trigger personal nostalgic memories for the giver and elicit the warmth of fond personal experiences. This warmth would be imbued to the organization evoking the emotional engagement. Emotional engagement is key to donor commitment, and donors who are emotionally engaged are more likely to give to charity (Sarganet et al., 2006). This could facilitate the creation of long-term intimate relationships between nonprofits and key donors. It would seem reasonable that stirring up memories related to significant personal experiences could be particularly helpful for such organizations as universities, 
hospitals, schools and social causes as well as health-related charities. Marketing Managers of these NPOs could benefit by identifying significant personal experiences of the donor and evoking nostalgia by giving them a window to re-experience those events.

\section{ORGANIZATION OF THIS DISSERTATION}

The rest of the dissertation is organized as follows. Chapter two presents an indepth review of the relevant literature related to giving behavior, personal nostalgia and the factors that influence personal nostalgia. The conceptual model is discussed in greater detail and the research hypotheses are presented. Chapter three then examines the methodological issues with a discussion of various scales to measure the psychological constructs and their psychometric properties. Chapter four presents a discussion of the data collection process and an assessment of the model constructs and how the structural equations model is run and the various hypotheses are tested. Finally chapter five presents theoretical and managerial implications, limitations and suggestions for future research. 


\section{CHAPTER 2: REVIEW OF THE LITERATURE}

\section{INTRODUCTION}

This chapter focuses on the review of the relevant literature. At first a review of the giving behavior literature is presented. The focus then moves to a review of the literature on nostalgia and the experiences of personal nostalgia. The chapter then also discusses in detail the various factors that affect personal nostalgia. Finally the theoretical model linking personal nostalgia and charitable giving is presented and related research hypotheses are posited.

\section{GIVING BEHAVIOR}

Non-profit organizations attracted more than $\$ 250$ Billion in donations in 2005 from individuals (Lipman, 2007). Individual giving represents $75.6 \%$ of all philanthropic giving (Giving USA, 2007). However, what is troubling for non-profit managers is that there has been a decline in the number of givers (Association of Fundraising Professionals, 2007) and thus NPOs must increase the donations from current givers to make up for the decline in the number of givers. An examination of giving trends shows that both the most and least affluent individual givers give more proportionally than their middle-income counterparts (Silver, 1980).

Giving can take many forms. It includes outright financial donations, planned giving (regular giving - this could be during the giver's lifetime, (e.g. Kottasz, 2004), or after his or her death in the form of legacies, (e.g. Webber, 2004), and hybrid giving (a mixture of outright and planned giving, (e.g. Brown, 2004). Givers may also express their support for charitable causes by attending fundraising events (Webber, 2004; Kottasz, 2004) and 
by buying related merchandise/mementos (Mottner and Ford, 2003). Other forms of giving include time and talent types of gifts, but these are beyond the scope of the present study.

Giving behavior and the motivation for giving vary across different groups of givers. Radley and Kennedy (1995) found that lower-income givers were motivated by empathy while wealthier givers were concerned with bringing about social change. There are also sexual differences in giving behavior. Women tend to give smaller amounts but to a greater number of charities than men. (Braus, 1994). Studies have also shown that underlying religious conviction also has a direct positive effect on giving (Edmundson, 1986; Halfpenney, 1990). What is apparent in an examination of this literature is that most of the charitable giving is done by older adults (Mathur, 1996; Pharoah and Tanner, 1997), while the younger generation is less motivated to give (Sargeant et al., 2000). This appears to be primarily due to the breakdown of traditional family units and the increasing pace of life (Kottasz, 2004) along with a desire to fulfill increasing materialistic needs (Kottasz, 2004). The important opportunity for non-profit managers is that non-givers have been found to give when they feel a genuine interest and identification with the cause (Sargeant and Jay, 2004). As an example, young males have been found to be attracted to arts and cultural charities (Kottasz, 2004). If NPO managers can engender that identification, they can improve their financial health while increasing their potential impact on the cause involved. 


\section{Intrinsic determinants of giving}

All motives for giving are not altruistic. There are also non-altruistic motives for giving. Giving may result in a direct gain to the giver. Pure altruistic motives include a warm feeling or glow (Andreoni, 1990), a desire to cause social change (Radley and Kennedy, 1995), empathy, sympathy, fear, guilt, pity (Feldman, 1985; Fultz et al., 1986) and a pure belief in the cause (Webber,2004). The non-altruistic motives are either emotional or economic. Emotional benefits include the achievement of prestige and respect (Olson, 1965) in the community, self-esteem (Mathur, 1996), recognition (Kottasz, 2004), the alleviation of peer pressure (Webber, 2004) and the diffusion of negative feelings (Cialdini, 1987). Economic benefits are those benefits which result in a direct economic or monetary benefit to the giver. It includes such things as tax incentives, free entry tickets and invitations to dinners, art performances, gala events (Kottasz, 2004; Sargeant et al., 2006), etc. Sargeant et al. (2006) summarized the intrinsic determinants of giving under three categories: familial utility (benefits to family members either alive or in memoriam), emotional utility (emotions felt) and demonstrable utility (a direct economic benefit accruing to the giver).

\section{Giving as a relationship}

In this burgeoning era of relationship marketing, the focus is on establishing longterm intimate relationships between buyers and sellers. Equally appropriate is the establishing of a relationship between donor and recipient (Belk, 1979). Building relationships with consumers helps move the company from one-time transactions to long term "partnerships" of exchanges (Morgan and Hunt, 1994). For this to happen, it is proposed that commitment and trust are vital to create and maintain relationships. 
(Morgan and Hunt, 1994). Trust and commitment also drive giving behavior (Sargeant and Lee, 2004). Trust is the confidence in the other party's reliability and integrity (Morgan and Hunt, 1994), and in the not-for-profit literature, trust has been found to be influenced by two organizational factors: the professionalism demonstrated by the charity and the quality of its communications (Sargeant et al., 2006). Commitment is the enduring desire to maintain a valued relationship (Morgan and Hunt, 1994). Those who develop commitment to charitable organizations remain in these relationships as it serves to reduce uncertainty and vulnerability (Sargeant et al., 2006). The degree of personal association with the cause affects the commitment to the cause (Sargeant and Lee, 2004). The higher the levels of emotional utility (emotions felt out of giving) and familial utility (link to family), the greater the degree of commitment and the greater the level of giving that is exhibited by the donor to that charitable organization (Sargeant et al., 2006). The perceived demonstrable benefits (selfish gains like invitations to gala events (Kottasz, 2004)) associated with charitable giving helps to persuade non-donors to become donors. However, it does not impact commitment nor does it impact trust in the charitable organization (Sargeant et al., 2006).

In order to increase giving among current givers and bring in new younger givers, NPOs need to focus on emotional constructs which can drive commitment to the charity, which in turn can increase giving behavior. This study proposes that one such emotional construct is nostalgia.

\section{NOSTALGIA}

There is much academic discussion on nostalgia. Many scholars have described it as a fatal disease, which everyone experiences at one time or another (Hofer, 1688). Many 
others have called it a hook of continuity in changing times (Tannock, 1995). They argue that the more dissatisfied consumers are with life as it is today, the more they will want to revert back to the ways of the past (Baker and Kennedy, 1994). Still others argue that since baby boomers are aging, they are becoming increasingly nostalgic (Unger et al., 1991; Stern, 1992). As a result, there is a growing interest in the use of nostalgia in marketing (Baker and Kennedy, 1994).

There are four broad definitions of nostalgia. The first is the temporal definition: "A positive feeling for the past, with a negative feeling for the present or future...THINGS WERE BETTER...THEN THAN NOW" (Davis 1979, page 18). The second describes nostalgia as a sad mood: "A wistful mood that may be prompted by an object, a scene, a smell or a strain of music" (Belk, 1990, page 670). Holbrook and Schindler, 1991, define nostalgia on the basis of what cued the occurrence of nostalgia: "A preference toward objects that were more common when one was younger" (page 332). Finally Holbrook (1993) provides a more comprehensive definition: "A longing for the past or a fondness for possessions and activities associated with the days of the past" (page 245). The Holbrook (1993) definition is more widely used in the literature (e.g. Holak and Havlena (1998), Schindler and Holbrook (2003)) since it encapsulates the emotions involved in the nostalgia experience. As this study proposes a link between the emotional utility and familial utility arising out of personal nostalgia and charitable giving this study will employ the definition proposed by Holbrook (1993).

There are cognitive as well as affective dimensions to the experience of nostalgia (Werman, 1977; Baumgartner, 1992). The cognitive side focuses on the memories of the past, and the affective side involves the emotions that these memories evoke. Research 
has shown that by stimulating the consumer's memory, they can be made to feel the emotions they felt when they had the original experience (Braun-Latour and Latour, 2005). By providing stimuli to consumers which remind them of days gone by, marketers can evoke emotions of the past which the consumers are hoping for. This would help emotionally engage the consumer and strengthen the existing emotional bonds. It should be noted that the emotions that are associated with nostalgia are complex. The nostalgic experience is not comprised of all positive emotions; it is a "bittersweet" experience (Davis, 1979). Nostalgia evokes both positive and negative emotions (Holak and Havlena, 1992). By remembering the past, the person feels warmth, joy and affection (Holak and Havlena, 1998), but at the same time, there is a feeling of sadness and loss with the realization that the past cannot be recreated. (Holak and Havlena, 1998).

Some individuals show higher propensities for nostalgia than others (Holbrook, 1993). Therefore even among the same age group some people may be more nostalgic than others. Nostalgia proneness is thus a facet of a person's personality. Nostalgia proneness (propensity to become nostalgic) is influenced by the individual's life stage and other personal factors. Holbrook (1993) defined nostalgia proneness as "a facet of individual character- a psychographic variable or aspect of life-style, or a general customer characteristic-that may vary among consumers (p 246)". Batcho (1998) also explained that a person highly prone to nostalgia, rather than being depressed, would have a better capacity for emotionality. Therefore he or she would be very happy when feeling happy and very sad when feeling sad. His or her capacity to feel emotions more intensely would increase the likelihood of experiencing both the "sweet" and the "bitter" emotions of nostalgia. Individuals in the high nostalgia group were found to perceive the 
past as more favorable than those in the low nostalgia group (Batcho, 1998). Therefore, people who are more prone to nostalgia are more open to nostalgic appeals, branding strategies and advertising (Zimmer et al., 1999).

Nostalgia is evoked by a variety of triggers (Holbrook and Schindler, 2003; Schindler and Holbrook, 1993). Nostalgia can be triggered by sensory experiences (pleasurable sensory experiences from the past), links with the individual's homeland (bonding with objects associated with a distant land), items that remind the individual of rites of passage, friends and loved ones (objects representing close social relationships), objects linked with aspects of continuity and security, and finally items associated with the arts, culture and entertainment (mental or spiritual freedom). Researchers have also found that men and women have different triggers for nostalgia (Baker and Kennedy, 1994). There are two types of nostalgia, personal or direct nostalgia and vicarious nostalgia (see Table 2-1). Each of these would be discussed in order. 


\section{Table 2-1 \\ Types of Nostalgia}
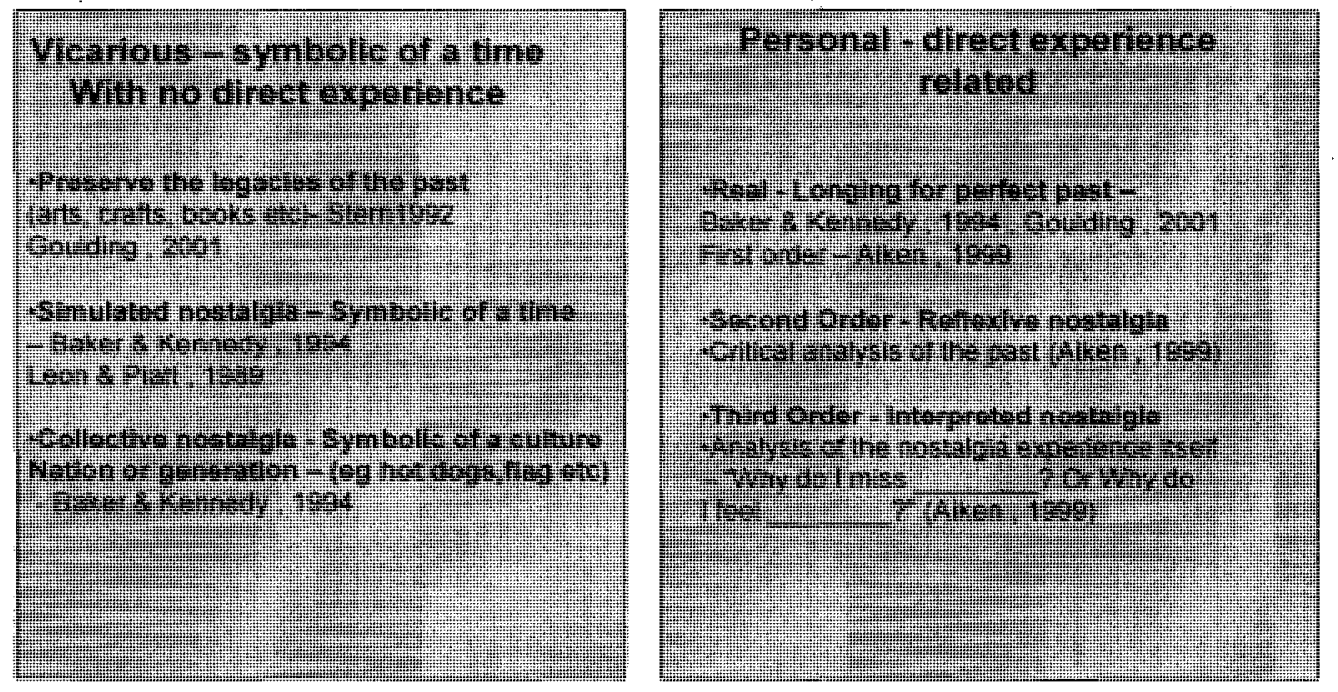

\section{Vicarious Nostalgia}

"Vicarious nostalgia deals with nostalgia for a period outside of the individuals living memory" (Goulding, 2002, p 542). This nostalgia is not linked to any direct personal experience in the past. Unlike personal nostalgia, it is the grieving for the loss of something that was never directly experienced by the individual in their past (Croft, 1989, Baker and Kennedy, 1994). It is not influenced by age. Goulding (2002) found that even 25 year olds felt nostalgic for the era of the 1960s. Vicarious nostalgia represents a yearning for traditional, conservative and community values of past eras. Experiencing vicarious nostalgia is an individualized blend of fantasy and reality (Rose and Wood, 2005). It is remembering times which an individual has not personally experienced but yearns for. Sohn (1983) argues that vicarious nostalgia should be considered as paramnesia that is the feeling that one has seen it before or heard it before, the basis of 
which could be pure fantasy. Vicarious nostalgia is transformative (Sohn, 1983). For example, by attending an Opera, the audience might feel transported to another era and briefly relive that era. A visit to a museum becomes a retreat from the real world, spatially and temporally, and a transportation to the real times of the past (Joy and Sherry, 2003). When indulging in vicarious nostalgia, the past becomes present, which is followed by a feeling of loss and melancholy that the past was but a thought and not a reality (Daniels, 1985). Therefore vicarious nostalgia becomes a quest for an illusion that can never be found. This identification with the past influences thought, action and behavior (Goulding, 2002). Individuals experience the authentic "golden" past vicariously by consuming objects that help take them back to that time (Rose and Wood, 2005). The factors that have been found to influence vicarious nostalgia are discontinuity, alienation and a search for authenticity (Stern, 1992).

Discontinuity: Like personal nostalgia, vicarious nostalgia can also serve as a basis for coping with discontinuity. When faced with uncertainty and anxious circumstances, individuals tend to go back in time and link with the past as that gives them a sense of security. It represents an "old tweed coat" (Davis,1979), as much as many things may change, there are always some things that remain the same. Thus, the link to the past provides a hook of continuity in turbulent times (Davis, 1979; Tannock, 1995). In other words, it facilitates an escape from the problems of reality by allowing the individual to seek shelter in the security of the past (Baudrillard, 1983).

Alienation: Alienation refers to "the separation of human beings from fellow human beings and from their institutions" (Kanungo, 1979, p 120). This could be related to the workplace, the changing face of the family, etc. In a traditional society people have 
stronger connections and roots with family and other social institutions. Unbridled individualism leads to extreme competition and thus people tend to feel that personal interests are incompatible with those of others. Hence a positive outcome for one would have to mean a negative outcome for another (Waterman, 1981). Adding to this, the fast pace of life has led to pressures, frustrations, and a lack of interpersonal involvement (Bewes, 1997, Lears, 1998). This has resulted in individuals leading more private lives and a society which is impersonalized (Chase and Shaw, 1989). Some people no longer have strong ties with one another. This would lead to a decline in the feeling of belongingness and security. If individuals feel the need to be associated with societal groups but are unable to do so, this will lead to frustrations and insecurity thus making the individual feel a sense of meaninglessness in life and loneliness (Kanungo, 1979). By indulging in vicarious nostalgia, individuals indulge in the values of a community of the past, or connect with times when they perceive that family and social groups had a presence and meaning in everyday life (Daniels, 1985). Thus the transference to another era through vicarious nostalgia becomes a way of healing the sense of insecurity and loneliness. By identifying with specific objects associated with nostalgia, individuals will experience the times when they believe that community values were cherished. Individuals experiencing vicarious nostalgia feel that they are a part of a group sharing the same interest and hence form a collective identity. This creates a "neo tribe" where the group shares something in common that is mutually valued. This becomes a basis for socializing and building alternate communities (Maffesoli, 1996). This therefore serves as the foundation for a larger identity for the marginalized individual (Price et al., 2000). An example of this is the reliving of the "mountain man myth" fantasy, where a 
group of people get together and live, dress, eat and drink just like the mountain men did many years ago. Not only does it enable them to relive the days when there was a strong sense of community, but it also helps create a social group of people for friendship, bonding, and networking among those with a common interest (Belk and Costa, 1998). This would apply for many who practice creative anachronism and dress and act as those from different periods of history.

Search for authenticity: Authenticity of an object refers to its perceived genuineness (Trilling, 1972). Authenticity gives a feeling of purity and sacredness. For some people nothing appears as how it should be. Products, fashion, art, and even the role of the family is perceived to have deteriorated. Lears (1998) argues that the individualist culture of pleasure seeking has created disillusionment with everyday life. It is this discontentment with the present that creates an urge to seek a "golden age" of the past (Chase and Shaw, 1989). For some individuals, they cannot believe what has happened around them (Baudrillard, 1983). This has prompted a feeling of deterioration and decline with a need for authenticity (e.g., the Coke catch phrase "The Real Thing" as suggested by Belk, Wallendorf and Sherry, 1989) and for a simpler and more authentic way of life away from present day complexities (Seremetakis, 1994). Thus, when the present is no longer appealing, individuals want to simulate (Baudrillard, 1983) and create an alternate "authentic" reality (Firat and Venkatesh, 1995). This authentic object of the past is perceived to be genuine, true and eternal.

Vicarious nostalgia therefore offers a link to the past and the values associated with that past (Lears, 1998). The authenticity of the past gets resurrected by the experience of nostalgia and the individual relives that authentic past. Nostalgia becomes a 
way to take refuge away from everyday life retreating into the values of the past. This is reflected in the consumption undertaken by the individual. For example, Belk (1991) argues that individuals consume antiques or antique looking memorabilia because it evokes a time associated with the era to which the antiques belong, which is valued or admired by the owner. It is these positive emotions that give a sense of continuity and a feeling of authenticity and nostalgic escapism.

\section{Personal Nostalgia}

This is based on the person's direct experiences. It is a longing for the actual "lived" past (Baker and Kennedy, 1994) and the things, memories and people associated with that past (Goulding, 2001). The person experiencing personal nostalgia remembers things and events more positively than they actually were. They look to the past as if it represents the way things should always be and regret the fact that things have changed (Bricklin, 2001; Stern, 1995). Therefore, the person experiencing nostalgia is not only looking for the object of nostalgia but the time before it was lost (Ahktar, 1996; LomskyFeder and Rapoport, 2000). Personal nostalgia serves different functions. It serves as an anchor of continuity and identity (Mehta and Belk, 1991) during changing circumstances in life (Noble and Walker, 1997). When circumstances change, people feel insecure and unsure of themselves and therefore tend to revert to past memories for comfort and support amidst fears of an uncertain future (Nawas and Platt, 1965). It also helps to alleviate feelings of loneliness (Lomsky-Feder and Rapoport, 2000). When people feel lonely, they tend to remember past events with friends and family and relive the times which were happier. 


\section{THE PERSONAL NOSTALGIA EXPERIENCE}

Models of autobiographical memory (Conway and Pleydell-Pearce, 2000) state that memory is organized in a hierarchical manner. The upper layers contain general information and are linked to the more specific and detailed lower layers. A general memory is a general summary of events over extended periods of time (e.g.,. school years). Specific memories, on the other hand, contain descriptions of events at a particular time (e.g., a $21^{\text {st }}$ birthday, wedding day, graduation, etc.). In the model proposed by Conway and Pleydell-Pearce (2000), the specific memory is rich in sensoryperceptual detail. For example, the memory of a birthday party may bring to mind the emotions felt, the look of the guests, the music played, etc. (Mansell and Lam, 2004). Research has shown (Williams et al., 1999) that specific memories are more likely to involve mental imagery than general memories. Consistent with this, brain imaging studies have shown that the retrieval of specific autobiographical events involves the activation of the posterior regions of the brain that are associated with mental imagery (Conway, 2001). Mental Imagery has been defined as a "process by which sensory information is represented in working memory in the absence of genuine and perceptual counterparts" (MacInnis and Price, 1987, p 473). Imagery recall is a multi-sensory experience. It involves visual elements, taste, smell, touch, etc. (MacInnis and Price, 1987). MacInnis and Price (1987) stated that imagery plays an important role in reliving past experiences. Davis (1979) stated that personal nostalgia is the reconstruction and reliving of the past. It refers to 'remembering' or 'recollecting' autobiographical events of the past. Remembering involves the individual re-experiencing of the event with details. Since personal nostalgia involves remembering past memories in detail, the 
nostalgic experience involves the summoning up of the images of the past, such that the distinct past becomes disconcertingly close (McDermott, 2002).

Morris and Hampson (1983) state that in order to understand the dimensions of mental imagery, the vividness and the quantity of images must be measured. The vividness of evoked images refers to the clarity with which the individual experiences these images. It has been termed as the most important characteristic of the imagery experience (Betts, 1909; Baumgartner, 1992). The clearer the quality of images recalled, the richer the mental imagery experience. Another aspect of imagery measurement is the quantity of images evoked. It has been argued that the greater the number of images recalled, the richer the imagery experience (Ellen and Bone, 1991). The number and quality of images recalled are not the same. For instance, one person may recall many images with low vividity, whereas another may recall just a few images but with high vividity (Ellen and Bone, 1991).

The personal nostalgia experience involves recalling experiences of the past and feeling the emotions of nostalgia (Holak and Havlena, 1992). Maclnnis and Price (1987) stated that imagery plays an important role in reliving past experiences. The nostalgic experience involves the summoning up of the images of the past, such that the distinct past becomes close (Probyn, 1996). It is the summoning of the images of the past with an accompanied longing (McDermott, 2002). The recall of the past leads to the evoking of both happy and sad emotions (Bernsten and Rubin, 2002; Holak and Havlena, 1992). There is the warmth and comfort in the past along with the accompanying pain, regret and sadness that the past cannot be relived (Davis, 1979). 
Baumgartner (1992) studied the emotions experienced while remembering key experiences of the past while listening to music. He found that the emotions evoked by personal nostalgia in this context loaded onto five groups. They were happiness/arousal, serenity, sleepy, tired and the negative emotion of gloominess. However, looking beyond the emotions related to music, in a broader context of personal nostalgia, Holak and Havlena (1998) found that the emotions evoked during personal nostalgia loaded onto six different emotional factors. They asked individuals experiencing nostalgia to write down their nostalgic experiences, and two sets of judges were then asked to rate the emotions that would have been felt by the authors of the nostalgic accounts. The six emotional factors were identified as follows: the positive emotions of tenderness/warmth, elation and serenity and the negative emotions of irritation, loss and fear. More recently, Wildschut et al. (2006) measured the emotions experienced during the nostalgic experience and found that the positive emotions exceeded the negative emotions, and that rather than evoking "exhuberation" or "exaltation", nostalgia evoked a "gentle contentment".

The positive emotions of the personal nostalgia experience arise from remembering the past while the negative emotions arise from the sense of loss. The key question is whether people can feel happy and sad at the same time or whether the two sets of emotions are bipolar (e.g., the person experiencing personal nostalgia either feels happy or sad)? Russell and Carroll (1999) stated that positive and negative emotions are bipolar, that is when someone felt happy, he or she could not feel sad and vice versa. However, Diener and Iran-Nejad (1986) found that positive and negative emotions often occur concurrently at moderate levels. Therefore, they said that when one feels happy, 
one can also feel sad, and thus positive and negative emotions may coexist. Cacioppo and Bernston (1994) found that the neural processes involved in positive and negative affect are partially distinct and hence raise the possibility that these systems can be co-activated. Larsen et al. (2001) found that in at least three situations (watching a powerful film "Life is beautiful", moving out of a dormitory, and graduation day) people felt positive emotions (happy, calm, relaxed, etc) and negative emotions (sad, depressed, etc). They found that while only $20 \%$ of the participants felt both happy and sad on a typical day, $50 \%$ felt happy and sad on graduation day. At graduation the subjects were happy that they had completed their degree but were also sad when they remembered the good days they had had in college. These studies support the possibility that positive and negative emotions can both coexist.

\section{FACTORS INFLUENCING PERSONAL NOSTALGIA}

Personal nostalgia is influenced by many factors. They include discontinuity, past experiences, loneliness, age and the recovery from grief. Each will be discussed in turn. Discontinuity: People experiencing discontinuity tend to become nostalgic (Davis 1979). Negative and stressful events in life may result in depression and negative feelings which the person must deal with (Tesser and Beach, 1998). This is evident when a loved one passes away, when one moves to a new country, the loss of a job or any event which disturbs the equilibrium of life. When faced with these disjunctive episodes, individuals tend to draw on inner resources so that they can restore a sense of stability, security and continuity (Elson 1992). The individual then clings to objects and events experienced in the past. The individual looks for a stimulus which enables him or her to elicit the memories of the past. This could be a strain of music, a memory or a current experience. 
This leads one to revive the past and re-experience the memories and emotions of days gone by (Ornstein and Ornstein 1985). Nostalgia provides a mesh of security and helps the individual to alleviate the insecurity that discontinuity brings. Best and Nelson (1985), found that men who traveled a lot tended to be more nostalgic than women who stayed at home. Mehta and Belk (1991) found that Indian migrants to the U.S. would keep objects from their home in India in their U.S. homes and would often indulge in personal nostalgia while coping with the separation from their homeland. The objects of nostalgia help to maintain a sense of continuity (Belk 1990). For example, when a loved one dies, his or her belongings become objects that can remind the individual of the deceased person and bring back associated memories and emotions.

Past experiences: Nostalgia is influenced by past experience. The more intense the past experience, the stronger the memories associated with that experience (Baumgartner, 1992; Holbrook, 1993). Events which have been more intense or more significant are retained (hence, more vivid) in the autobiographical memory more than less intense and less important events (Sehulster, 1989). In a study of the recall of 25 seasons of the Metropolitan opera, Sehulster (1989) found that individuals better recalled those seasons which had intense emotions or significant events linked to them. For instance, one individual remembered the 1979-80 season of opera more than any other season because it was the first that his wife and he had attended together. Novel events are also remembered better (Rubin et al., 1998). These events are remembered better because they are subject to more elaborate cognitive processing because of their novelty, as they are distinct from other events. Events associated with life scripts are also recalled better. Life scripts refer to developmental changes that are expected to take place at 
various points of life and different life phases that people are expected to live through at different ages (Bluck and Habermas, 2000; Clarke, 1995). For example, graduation, marriage and childbirth are part of the life script. Since these events are recalled better, people get more nostalgic for these events as they have special memories around these events. Does this mean that non significant events are not recalled? Sehulster (1989) found that the non significant events recalled were neither accurate nor precise, and there was much distortion.

Loneliness: In one national survey (Bradburn, 1969) 26\% of Americans reported having felt very lonely or remote from others during the recent past. In traditional societies people had stronger connections and roots with family and other social institutions. Some people no longer have strong ties with one another, which leads to a decline in the feeling of belongingness and security. Though individuals feel the need to associate themselves with groups, they are unable to do so. This leads to frustrations and insecurity making the individuals feels a sense of meaninglessness in life and thus loneliness (Kanungo, 1979). Loneliness is related to a number of personal characteristics including low self esteem, shyness, a feeling of alienation and a lack of control (Jones, Freemon and Goswick, in press). Among both younger and older adults loneliness is linked to negative affects including boredom, unhappiness, and dissatisfaction (Perlman, Gerson, and Spinner, 1978). Personal nostalgia also helps to alleviate feelings of loneliness (Lomsky-Feder and Rapoport, 2000). When people feel lonely, they tend to remember past events with friends and family and relive the times which were happier.

Aging: Is personal nostalgia purely a factor of aging? Certainly as people age, they develop a preference for bygone days (Davis, 1979). Some say that personal 
nostalgia is a part of the normal aging process. For example, Batcho (1995) found that as people aged they got more nostalgic and remembered the times of their youth with considerable nostalgia as they entered older stages in life. However, some studies show that nostalgia is not purely a function of age. Nostalgia rises and wanes across different age groups depending on the experiences and the demands imposed by life. For example, Batcho (1995) found that some young college students were found to be more nostalgic than some older individuals. Larsen et al. (2001) measured the emotions felt by students graduating and the emotions felt by students moving out of their dormitories. These instances made the individuals experience nostalgia with both the positive emotions of happiness and the negative emotion of regret felt at the same time.

Recovery from grief by continual involvement with the deceased: Is there a relationship between grief and nostalgia while giving in memoriam? Is giving in memoriam only a reaction to grief? Would this wane over a period of time? A review of the literature on grief shows that there are three phases of grief (Goalder, 1985). The first phase is comprised of disbelief in the death of the loved one. It is a phase of shock. The second phase refers to the beginnings of coping with the death. This involves a search for meaning in the death. This also involves a searching for the dead individual in his or her belongings and memories. The final phase is recovery. This involves proceeding with life and overcoming the pain involved. However, this does not mean that the individual stops grieving for their loved one. Scharlach (1991) found that when some adults were reminded of the death of their parent, they cried even years after the death of that parent. Personal nostalgia refers to the remembering of the events of the past and reliving the positive emotions with a sense of loss. Thus, one can argue that getting nostalgic for a 
loved one who is dead allows them to cope with the loss and the grief involved with the death. Bonnano and Kaltman (1999) argued that one of the means of coping with the death of an individual is to develop "continued bonds with the deceased to "foster" the continuity of identity" (p 562). Recently, Carnelly et al. (2006) found that grief due to the death of a spouse among widows led to a feeling of continual involvement and emotional resolution. The griever would often talk with the deceased and wanted to feel his presence in her life. The griever often felt that she had not received closure with the deceased emotionally and wanted to say many things to the deceased which she had not had the chance to say. Therefore, it appears that by making a donation in the memory of the deceased, the giver remembers the loved one and is provided a sense of continuity. Therefore, one can argue that it helps in the grieving process as it aids in recovery from the grief.

Memories of a loved one may simultaneously bring comfort and also cause distress. Weiss (2001) found that emotionally charged objects (objects which had a special meaning in the relationship like an anniversary gift) from the loved one led to the bereaved feeling a continued connection with the deceased. Many theorists have maintained that the memories of the deceased person decline over time (Worden, 2002), however, this assumption has been questioned recently. Bonnano et al. (2004) found that it was common for the bereaved to think about their loved one almost daily in the first six months but this dropped down to around four times a week 18 months after the death. This reduction in thinking about the deceased comes as a result of coping, by getting on with life, as well as through gaining comfort from the positive memories of the deceased. In many cases the bereaved still ruminated about the loved one or even had conversations 
with the deceased spouse. The grievers felt a continual connection with the deceased and wanted some kind of emotional closure. Carnelly et al. (2006) found that the positive emotions that were evoked with the memories of the deceased did not change with time. Even though the frequency of thoughts that resulted in negative emotions were reduced over time, the frequency of thought that resulted in pleasantness did not drop over time. Therefore one can say that while thinking of the loved one, the bereaved remembers the loved one and it is likely that he or she will get nostalgic about the person. This continual connection with the loved one can prompt him or her to give to a charity in memoriam of the loved one.

\section{PROPOSED CONCEPTUAL MODEL AND RESEARCH HYPOTHESES}

Looking to the work of Sargeant et al. (2006), charitable giving is affected by commitment, which in turn is affected by trust and by emotional and familial utility, which are intrinsic, while trust is driven by organizational elements such as organizational professionalism and quality of communications, which are extrinsic.

The proposed model here (Figure 2-1) extends the work of Sargeant et al. (2006). The model proposes that the emotional engagement associated with personal nostalgia is likely to have a bearing on both emotional and familial utility. Personal nostalgia is likely to impact the emotional utility and familial utility derived by the giver, which in turn would drive commitment. The effective use of advertising cues to elicit nostalgic reactions to ads or communications would be expected to affect the donor's feelings about the organization doing the communicating/advertising. The positive potential associated with the reliving of fond personal experiences and memories and/or the 
connection to a happier past should enhance the chance of donor giving to the charity in question. However, the extent to which the NPO can evoke nostalgia depends upon the life stage of the donor and involves the discontinuity he or she feels, the loneliness he or she feels, the emotional importance of the past experiences evoked by the NPO and the recovery from grief. The rest of this chapter will discuss the hypotheses connected to the various linkages in the conceptual model.

Figure 2-1 - Conceptual Model

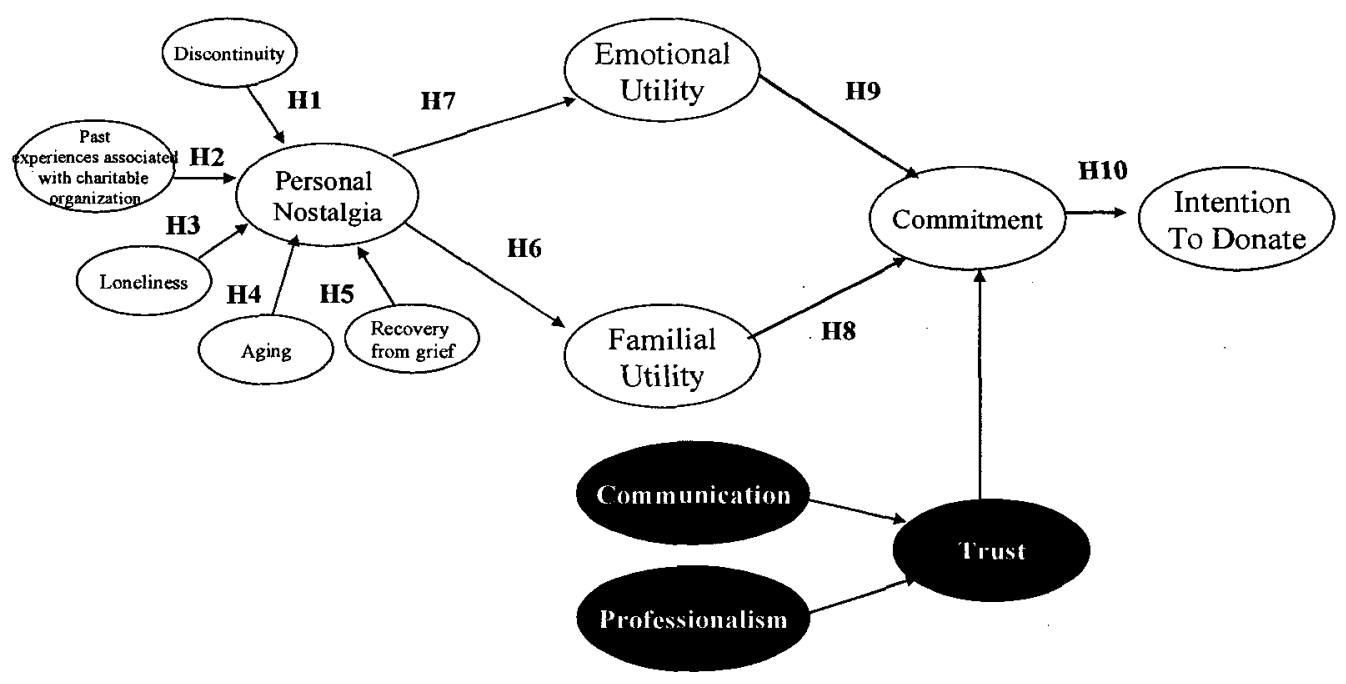

(Adapted from Sargeant et al, 2006) 


\section{Factors influencing personal nostalgia}

As discussed earlier, certain factors influence personal nostalgia among individuals. The factors that influence personal nostalgia are discontinuity, past experiences, loneliness, age and the recovery from grief.

Discontinuity: People experiencing discontinuity tend to become nostalgic (Davis 1979). Negative and stressful events in life may result in depression and negative feelings with which the person would want to cope (Tesser and Beach 1998). The individual then would cling to objects and events experienced in the past. This would lead him or her to revive the past and re experience the memories and emotions of the past (Ornstein and Ornstein 1985). Personal nostalgia provides a mesh of security and helps overcome the insecurity that discontinuity brings. It is argued that in the context of giving to charity NPOs that can assure continuity for donors facing discontinuity are likely to provide emotional benefits to the giver. For example, giving to a cancer hospital in memory of a person lost to cancer is likely to help the members of the bereaved family cope with the discontinuity. Therefore, it is hypothesized that:

\section{H1: There is a positive causal link between discontinuity and personal nostalgia}

Past experiences: Events which have been more intense or more significant for the individual would be retained (hence more vivid) in the autobiographical memory more than less intense and less important events (Sehulster, 1989). In a study of the recall of 25 seasons of the Metropolitan opera, Sehulster (1989) found that individuals recalled those seasons better which had intense emotions or significant events linked to them. Events associated with Life scripts are also recalled more effectively. For examplegraduation, marriage and childbirth are remembered better than other life events. Since 
these events are recalled better, people would be expected to get more nostalgic about these events as they have special memories. Thus it is hypothesized that:

\section{H2: There is a positive causal link between past experiences associated with the charitable organization and personal nostalgia}

Loneliness: Unbridled individualism leads to extreme competition and thus some people tend to feel alienation. Adding to this, the fast pace of life has led to pressures, frustrations and a lack of interpersonal involvement. This has resulted in individuals leading more private lives and an impersonalized society (Chase and Shaw, 1989). When people get lonely, they tend to get nostalgic about the days of the past and remember the events and people they associated with in their past. Thus it is hypothesized that:

\section{H3: There is a positive causal link between loneliness and personal nostalgia}

Aging: As people get older they tend to get more nostalgic (Davis, 1979). They tend to remember the days when they were younger. People long for the friends, loved ones and experiences of the past and want to relive the days now past. This is evident from the nostalgic appeals by various companies targeted towards the baby boomers (e.g. Unger et al., 1991). Hence, in line with extant literature, it is hypothesized that:

\section{H4: There is a positive causal link between aging and personal nostalgia}

Recovery from grief: Bonnano and Kaltman (1999) argued that one of the means of coping with the death of an individual is to develop "continued bonds with the deceased to "foster the continuity of identity" (p 562). Memories of a deceased loved one may simultaneously bring comfort and also cause distress. Bonnano et al. (2004) found that grievers felt a continual connection with the deceased and also wanted to get emotional closure. Carnelly et al. (2006) found that the positive emotions that were 
evoked with the memories of the deceased did not change over time. Even though the frequency of thoughts that resulted in negative emotions diminished over time, the frequency of thought that resulted in pleasantness did not decrease over time. Therefore, one can say that while thinking of the loved one, the bereaved remembers the loved one and it is likely that he or she will get nostalgic about that person. This continual connection with the loved one can prompt him or her to give to a charity in memoriam of the loved one. Therefore it is hypothesized that:

\section{H5: There is a positive causal link between recovery from grief and personal nostalgia.}

\section{Personal nostalgia and giving to charity}

With changing circumstances in life and aging, people remember the past with increasing fondness. They remember the experiences they have undergone. They begin to long for the past (Baker and Kennedy, 1994) and the things and memories of experiences and people associated with this past (Goulding, 2001). The triggering of nostalgia is associated with fond memories of friends and loved ones who may have died. Nostalgia opens a variety of positive and negative emotions. Though there is often a sense of loss, there is also comfort and warmth in the memories. In a charitable giving context, when thinking of one's loved ones, the individual is likely to feel a personal affinity for the people being remembered. This personal affinity should motivate the individual to donate to a charity in memoriam (Sargeant et al., 2006). In this case, the likelihood is that the giver will feel a connection to the past loved one through the giving of a gift in that individual's name (Fischer, Gainer and Arnold, 1996). This acts as a platform for the individual to experience nostalgia and hence be closer to the loved one. 
For example, if someone has lost a relative to cancer, by giving to charities associated with cancer in the name of the lost relative, this will help to keep the memory of the loved one alive and bring the individual a step closer to that lost relative or friend. This is what is described by Sargeant et al. (2006) as familial utility arising out of giving. Thus it is hypothesized that:

H6: There is a positive causal link between personal nostalgia and familial utility

Nostalgia creates a fantasized reunion with the idealized past. The person experiencing nostalgia is not only looking for the object of nostalgia, but the time before it was lost (Ahktar, 1994; Lomsky-Feder and Rapoport, 2000). Thus an academic institution could evoke nostalgia in their appeals for donations by stimulating school memories (Braun-La Tour et al., 2004) among its ex students. Hence by giving to his school, the individual would feel closer to his school days, reminding him of the memories of the past and thus experiencing nostalgia. This could result in feelings of elation, happiness, and warmth (Holak and Havlena, 1998). As a result, personal nostalgia would therefore contribute to emotional benefits (Sargeant et al., 2006). Therefore one would expect that the emotions evoked by personal nostalgia would result in emotional utility. Thus it is hypothesized that:

\section{H7: There is a positive causal link between personal nostalgia and emotional utility}

Commitment is the enduring desire to maintain a valued relationship (Morgan and Hunt, 1994), and those who develop a commitment to non-profits will maintain that relationship as it serves to reduce uncertainty and vulnerability (Sargeant et al., 2006). Certainly how much personal association the donor develops with the charity will affect 
the level of commitment he or she will have towards that charity (Sargeant and Lee, 2004). The higher the emotional utility and familial utility, the greater the degree of commitment and the greater the level of giving that will be exhibited by the donor to that charitable organization (Sargeant et al., 2006). The familial utility and emotional utility derived through personal nostalgia could be expected to strengthen the commitment to the charity. Logically then, charity giving becomes a way for the giver to reconnect with the past or feel close affinity to his or her lost loved one. This commitment to the charity drives giving behavior. Thus it is hypothesized that:

H8: There is a positive causal link between the familial utility derived through personal nostalgia and the commitment to the charitable organization

H9: There is a positive causal link between the emotional utility derived through personal nostalgia and the commitment to the charitable organization

H10: There is a positive causal link between the commitment to the charitable organization and the intention to donate

In this section the conceptual model was discussed, the linkages in the model were explained and research hypotheses were presented. In the next section the measurement of the constructs will be examined and the methodology that will be followed for collecting, analyzing the data and testing the research hypotheses will be discussed. 


\section{CHAPTER 3 : METHODOLOGY}

\section{INTRODUCTION}

The previous chapter presented a review of the literature, the conceptual model and research hypotheses. This chapter will present the discussion of the methodology that was employed to collect the data and test the proposed hypotheses. The scales for measuring the various constructs are examined along with a discussion of the sampling frame and mechanism for data collection.

\section{CONSTRUCT SCALES}

\section{Discontinuity}

Discontinuity was measured using the Life Experiences Survey (LES) developed by Sarason et al. (1978). The LES is a 45-item measure (Table 3-1) that was designed to capture a variety of life changes frequently experienced. Some examples are "Serious illness or injury of close family member, death of a close family member, marital separation, ending of education, new job etc. (Sarason et al., 1978, p 944)". The respondents are asked to check if they have experienced any of those events in the recent past and when. They are then asked to rate the positive $(+3)$ or negative $(-3)$ effect this may have had on them. This was tested among 345 respondents by Sarason et al. (1978) and was found to exhibit a reliability of 0.88 for the effect of negative events in life. This scale has also been used more recently by Tesser and Beach (1998) to measure the discontinuity experienced by families due to changes in life experiences. The authors studied the effect of discontinuity on the conflict in the parent / adolescent child relationship. They analyzed the effect of negative and positive life events separately. 
Another scale that has been used for measuring discontinuity was developed by Holmes and Rahe (1967) and is known as the Schedule of Recent Experiences (SRE). However, this scale has been criticized since it does not ask respondents how various life events have impacted them either positively or negatively, but asks them to judge as to how much social readjustment they were asked to make (Brown,1974, Sarason, De Monchaux and Hunt, 1975). It was therefore felt that this scale would not be relevant in the current context

\section{Table 3-1 - Life Experiences Survey (LES)}

Listed below are a number of events which sometimes bring about a change in the lives of those who experience them. Please check those events which you have experienced in the last 12 months. Also, for each item checked below please indicate the extent to which you viewed the event as having either a positive or a negative impact on your life at the time the event occurred. A rating of -3 would indicate an extremely negative impact. A rating of 0 suggests no impact either positive or negative. A rating of +3 would indicate an extremely positive impact.

\begin{tabular}{|c|c|c|c|c|c|c|c|c|c|}
\hline & & $\begin{array}{l}\text { Check if you } \\
\text { experienced } \\
\text { the event in }\end{array}$ & $\begin{array}{l}\text { If you } \\
\text { event }\end{array}$ & $\begin{array}{l}\text { did ex } \\
\text { mpact }\end{array}$ & $\begin{array}{l}\text { rienc } \\
\text { ou. }\end{array}$ & he e & nt, ho & did th & \\
\hline & & & 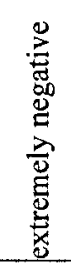 & 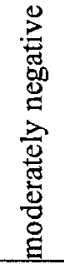 & 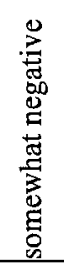 & 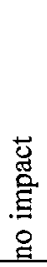 & 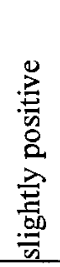 & 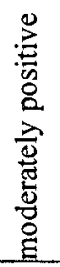 & 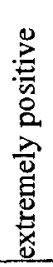 \\
\hline 1 & Marriage & & -3 & -2 & -1 & 0 & 1 & 2 & 3 \\
\hline 2 & Detention in jail or comparable institution & & -3 & -2 & -1 & 0 & 1 & 2 & 3 \\
\hline 3 & Death of a spouse & & -3 & -2 & -1 & 0 & 1 & 2 & 3 \\
\hline 4 & $\begin{array}{l}\text { Major change in sleeping habits (much more } \\
\text { or much less sleep) }\end{array}$ & & -3 & -2 & -1 & 0 & 1 & 2 & 3 \\
\hline 5 & Death of a close family member & & -3 & -2 & -1 & 0 & 1 & 2 & 3 \\
\hline 6 & $\begin{array}{l}\text { Major change in eating habits (much more or } \\
\text { much less food intake) }\end{array}$ & & -3 & -2 & -1 & 0 & 1 & 2 & 3 \\
\hline 7 & Foreclosure of mortgage or loan & & -3 & -2 & -1 & 0 & 1 & 2 & 3 \\
\hline 8 & Death of a close friend & & -3 & -2 . & -1 & 0 & 1 & 2 & 3 \\
\hline 9 & $\begin{array}{l}\text { Minor law violations (traffic tickets, } \\
\text { disturbing the peace etc) }\end{array}$ & & -3 & -2 & -1 & 0 & 1 & 2 & 3 \\
\hline 10 & Male : W.ife. girlfriend pregnancy & & -3 & -2 & -1 & 0 & 1 & 2 & 3 \\
\hline 11 & Female: Pregnancy & & -3 & -2 & -1 & 0. & 1 & 2 & 3 \\
\hline
\end{tabular}




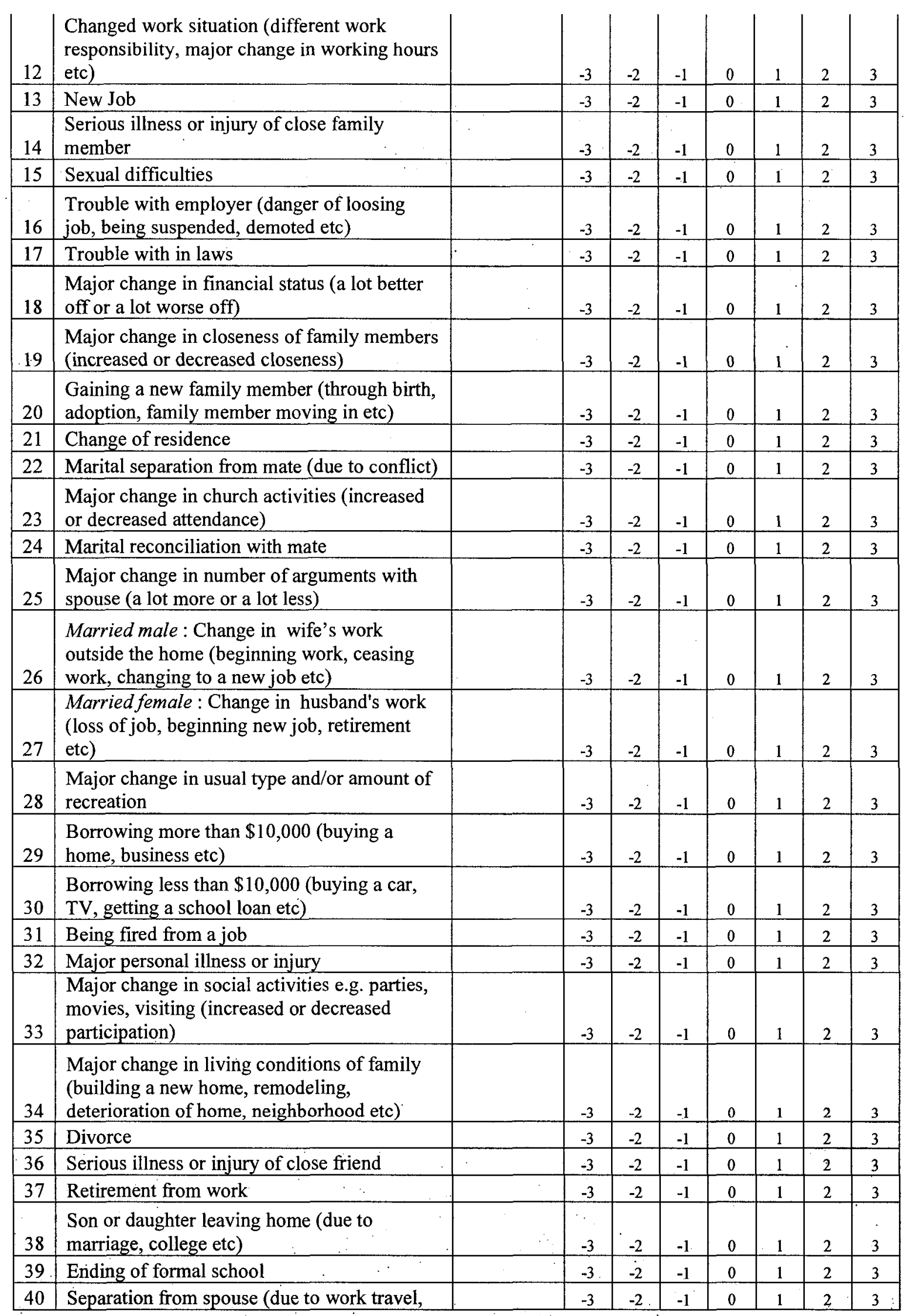




\begin{tabular}{|l|l|l|l|l|l|l|l|l|l|} 
& etc) & & & & & & & & \\
\hline 41 & Engagement & -3 & -2 & -1 & 0 & 1 & 2 & 3 \\
\hline 42 & Breaking up with boyfriend/girlfriend & & -3 & -2 & -1 & 0 & 1 & 2 & 3 \\
\hline 43 & Outstanding personal achievement & -3 & -2 & -1 & 0 & 1 & 2 & 3 \\
\hline 44 & Leaving home for the first time & -3 & -2 & -1 & 0 & 1 & 2 & 3 \\
\hline 45 & Reconciliation with boyfriend/girlfriend & & -3 & -2 & -1 & 0 & 1 & 2 & 3 \\
\hline
\end{tabular}

Source: Sarason et al. (1978)

Past experiences

The presence of significant past experiences linked with the charity in question were measured by following the approach used by Schulkind et al. (1999) and Baumgartner (1992). Schulkind et al. (1999) studied key life experiences linked to songs. They measured whether the songs cued any key event in the respondent's life. They asked the respondent whether the song reminded the respondent of anything from their life (Yes, a specific event/Yes, a general period/No). Baumgartner (1992) also studied how specific key life events get associated with certain songs. He asked respondents whether the music piece reminded them of any personal experience. He then measured the vividness of the memories evoked and the emotions that were aroused while remembering those events. He asked respondents, "How vivid are the recollections of the personal experience brought about by the piece of music?" (seven-point scale from notat-all vivid to extremely vivid) and "How emotional were the recollections?"(seven point scale from not-at-all emotional to extremely emotional). Since a review of the literature did not show any scales which measure the presence of significant life events associated with a charity in question, the measures used by Schukind et al. (1999) and Baumgartner (1992) were utilized in this study (Table 3-2). Instead of asking the memories associated with songs, the respondents were asked about their memories associated with charitable organizations. 


\begin{tabular}{|l|l|l|l|l|l|l|l|}
\hline \multicolumn{2}{|c|}{ Table 3-2 - Measure of the presence of a significant life experience associated with } \\
the charitable organization \\
\hline $\begin{array}{l}\text { Does this charitable organization remind you of any } \\
\text { personal experience? }\end{array}$ & & & & & & \\
\hline Yes & & & & & & & \\
\hline No & & & & & & & \\
\hline & & & & & & & \\
\hline & $\begin{array}{c}\text { Not at } \\
\text { all }\end{array}$ & & & & & & $\begin{array}{c}\text { Extr } \\
\text { emely }\end{array}$ \\
\hline $\begin{array}{l}\text { How vivid are the recollections of the personal } \\
\text { experience that you are reminded of when you think of } \\
\text { this charitable organization? }\end{array}$ & & & & & & & \\
\hline $\begin{array}{l}\text { How emotional were the recollections of the personal } \\
\text { experience that you are reminded of when you think of } \\
\text { this charitable organization? }\end{array}$ & & & & & & & \\
\hline
\end{tabular}

Adapted from: Schulkind et al. (1999) and Baumgartner (1992)

\section{Loneliness}

Loneliness was measured using the 20-item Revised UCLA Loneliness Scale (Table 3-3) developed by Russell et al. (1980). This scale utilizes statements that measures the loneliness felt by an individual. Examples of scale items include "I lack companionship and There is no one I can turn to ...". Russell et al. (1980) tested this scale among 237 individuals and it demonstrated good reliability (Alpha $=0.94)$. More recently this scale was used by Wildschut et al. (2006) to measure loneliness among students, the scores of which were then used to inform respondents if they were in the high or low loneliness condition.

The other scale available to measure loneliness is the Psychological Screening Inventory developed by Lanyon (1970). The Psychological Screening Inventory (1970) is a 130item scale which measures alienation, social non conformity and discomfort. The focus of this scale was on measuring these conditions among those who face major psychiatric 
disorder. Since this scale is overly lengthy and was developed to measure psychiatric disorders, it was felt to be inappropriate for use in this study.

\section{Table 3-3 - Revised UCLA Loneliness Scale}

Indicate how often you feel the way described in each of the following statements. Circle one number for each.

\begin{tabular}{|c|c|c|c|c|c|}
\hline & & Never & Rarely & Sometimes & Often \\
\hline 1 & I feel in tune with people around me & 1 & 2 & 3 & 4 \\
\hline 2 & I lack companionship & 1 & 2 & 3 & 4 \\
\hline 3 & There is no one I can turn to & 1 & 2 & 3 & 4 \\
\hline 4 & I do not feel alone & 1. & 2 & 3 & 4 \\
\hline 5 & I feel part of a group of friends & 1 & 2 & 3 & 4 \\
\hline 6 & I have a lot in common with the people around me & 1 & 2 & 3 & 4 \\
\hline 7 & I am no longer close to anyone & 1 & 2 & 3 & 4 \\
\hline 8 & $\begin{array}{l}\text { My interests and ideas are not shared by those around } \\
\text { me }\end{array}$ & 1 & 2 & 3 & 4 \\
\hline 9 & I am an outgoing person & 1 & 2 & 3 & 4 \\
\hline 10 & There are people I feel close to & 1 & 2 & 3 & 4 \\
\hline 11 & I feel left out & 1 & 2 & 3 & 4 \\
\hline 12 & My social relationships are superficial & 1 & 2 & 3 & 4 \\
\hline 13 & No one really knows me well & 1 & 2 & 3 & 4 \\
\hline 14 & I feel isolated from others & 1 & 2 & 3 & 4 \\
\hline 15 & I can find companionship when I want it & 1 & 2 & 3 & 4 \\
\hline 16 & There are people who really understand me & 1 & 2 & 3 & 4 \\
\hline 17 & I am unhappy being so withdrawn & 1 & 2 & 3 & 4 \\
\hline 18 & People are around me but not with me & 1 & 2 & 3 & 4 \\
\hline 19 & There are people I can talk to & 1 & 2 & 3 & 4 \\
\hline 20 & There are people I can turn to & 1 & 2 & 3 & 4 \\
\hline
\end{tabular}

Source: Russell et al. (1980)

\section{Recovery from grief by continual involvement with the deceased}

Bonnano and Kaltman (1999) argued that one of the means for coping with the death of an individual is to develop "continued bonds with the deceased to "foster" the continuity of identity" (p 562). Carnelly et al. (2006) found that the positive emotions that were evoked with the memories of the deceased did not change over time. Even though the frequency of thoughts that resulted in negative emotions decreased over time, the frequency of thoughts that resulted in pleasantness did not decrease over time. Therefore, one can argue that while thinking of the loved one, the bereaved remembers the loved one 
and it is likely that he or she will get nostalgic about that person. This helps the recovery from grief, as the griever feels that he or she has continual bonds with the deceased.

Recovery from grief was assessed using the measure developed by Carnelly et al. (2006): This measure (Table 3-4) was developed with reference to spousal death with reference to widows.

\begin{tabular}{|c|c|c|c|c|c|c|c|}
\hline \multicolumn{8}{|c|}{ Table 3-4 - Measure for Recovery from Grief } \\
\hline . & Never & $\begin{array}{l}\text { Less } \\
\text { than } \\
\text { once a } \\
\text { month }\end{array}$ & $\begin{array}{c}\text { About once } \\
\text { a month }\end{array}$ & $\begin{array}{c}2 \text { or } 3 \\
\text { times } \\
a \\
\text { month }\end{array}$ & $\begin{array}{l}\text { About } \\
\text { once a } \\
\text { week }\end{array}$ & $\begin{array}{c}2-3 \\
\text { times } \\
\text { a } \\
\text { week }\end{array}$ & $\begin{array}{l}\text { Dai } \\
\text { ly }\end{array}$ \\
\hline $\begin{array}{l}\text { How often during the last } 12 \\
\text { months did you have thoughts or } \\
\text { memories about a very close } \\
\text { relative / friend that is deceased? }\end{array}$ & 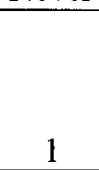 & 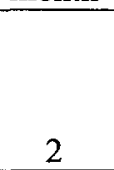 & 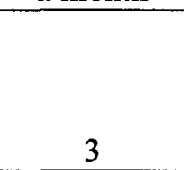 & . & 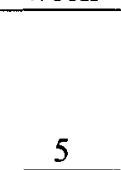 & 6 & 7 \\
\hline $\begin{array}{l}\text { How often during the last } 12 \\
\text { months did you talk about a very } \\
\text { close relative / friend that is } \\
\text { deceased? }\end{array}$ & 1. & 2 & 3 & 4 & 5 & 6 & 7 \\
\hline & Never & Rarely & Sometimes & Often & $\begin{array}{l}\text { Almost } \\
\text { always }\end{array}$ & & \\
\hline $\begin{array}{l}\text { How often thinking about your late } \\
\text { close relative/friend made you feel } \\
\text { happy? }\end{array}$ & 1 & 2 & 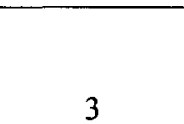 & 4 & 5 & & \\
\hline $\begin{array}{l}\text { How often thinking about your late } \\
\text { close relative/friend made you feel } \\
\text { sad? }\end{array}$ & 1 & 2 & 3 & 4 & 5 & & \\
\hline
\end{tabular}

Source: Carnelly et al. (2006)

\section{Personal Nostalgia}

Personal nostalgia was measured using the Personal Nostalgia Inventory (Table 3-5) developed by Batcho (1995). This comprises a 20-item survey on which respondents rate "the extent to which they miss each of the items from when they were younger" (Batcho, 1995, page 139). These items ranged from concrete categories like toys, TV shows, friends to abstract categories like the way society was then, the way people were then etc. Batcho (1995) tested her 20-item scale with 648 individuals. Using the split half method she found that the scale had good reliability $(r=0.78, p<.01)$. Using test retest method 
(administering this scale to the same individual twice, using an interval of one week), she found good correlation between the average rating across the twenty items $(r=0.84$, $\mathrm{p}<.01$ ). She also found that the more concrete items demonstrated better reliability (for example TV shows $r=0.84$, toys $r=0.81$, school $r=0.81$ ). More recently, Wildschut et al. (2006) used the Batcho (1995) scale to measure the effect of mood on personal nostalgia. They also found the scale to have good reliability $(\alpha=0.88)$.

The other scale that has been used to measure nostalgia is the scale developed by Holbrook (1993). This scale has statements that measure the proneness to both vicarious (longing for a time period not personally experienced) and personal nostalgia (longing for a time period personally experienced), as opposed to personal nostalgia alone (Batcho, 1995). In fact Batcho (1998) argues that if we eliminate the items with small loadings, the Holbrook (1993) scale really only measures vicarious nostalgia. Hence, she argues that the Holbrook (1993) scale is not a good measure of personal nostalgia. Since this study aims to measure personal nostalgia, the Personal Nostalgia Inventory developed by Batcho (1995) was appropriate for measuring personal nostalgia.

\begin{tabular}{|l|c|c|c|c|c|}
\hline \multicolumn{5}{|c|}{ Table 3-5 - Personal Nostalgia Inventory } \\
\hline & $\begin{array}{c}\text { Not at } \\
\text { all }\end{array}$ & & & & $\begin{array}{c}\text { Very } \\
\text { much }\end{array}$ \\
\hline & & & & & \\
\hline How much do you miss each of the following items from when you were younger: \\
\hline & 1 & 2 & 3 & 4 & 5 \\
\hline 1.Family & 1 & 2 & 3 & 4 & 5 \\
\hline 2.Heroes/Heroines & 1 & 2 & 3 & 4 & 5 \\
\hline 3.Not having to worry & 1 & 2 & 3 & 4 & 5 \\
\hline 4.Places & 1 & 2 & 3 & 4 & 5 \\
\hline 5.Music & 1 & 2 & 3 & 4 & 5 \\
\hline 6.Someone you loved & 1 & 2 & 3 & 4 & 5 \\
\hline 7.Friends & 1 & 2 & 3 & 4 & 5 \\
\hline 8.Things you did & 1 & 2 & 3 & 4 & 5 \\
\hline 9.Toys & 1 & 2 & 3 & 4 & 5 \\
\hline 10.The way people were & 1 & 2 & 3 & 4 & 5 \\
\hline 11.Feelings you had & & & & & \\
\hline
\end{tabular}




\begin{tabular}{|l|l|l|l|l|l|} 
12.TV shows/movies & 1 & 2 & 3 & 4 & 5 \\
\hline 13.School & 1 & 2 & 3 & 4 & 5 \\
\hline 14.Having someone to depend on & 1 & 2 & 3 & 4 & 5 \\
\hline 15.Holidays & 1 & 2 & 3 & 4 & 5 \\
\hline 16.The way society was & 1 & 2 & 3 & 4 & 5 \\
\hline 17.Pets & 1 & 2 & 3 & 4 & 5 \\
\hline 18.Not knowing sad or evil things & 1 & 2 & 3 & 4 & 5 \\
\hline 19.Church/religion & 1 & 2 & 3 & 4 & 5 \\
\hline 20.Your house & 1 & 2 & 3 & 4 & 5 \\
\hline
\end{tabular}

Source : Batcho (1995)

Emotional Utility (EU) and Familial Utility (FU)

Emotional utility refers to the emotional benefits donors derive out of giving to charity. Familial utility refers to the benefits of giving accruing to someone known to the giver such as a friend or a relative (Sargeant et al., 2006). For this study the scales developed by Sargeant et al. (2006) will be utilized (Table 3-6) to measure EU and FU.

Sargeant et al. (2006) developed scales to measure EU and FU along with four other constructs using the procedures recommended by Churchill (1979). They first started with a pool of 50 items to measure the constructs (based on extant literature). This was reviewed by a panel of judges. They shortlisted 42 items. These were then tested among 1000 individuals working in three public institutions. The final EU scale had two items and the FU scale had three items. These scales measure the emotional benefits and the familial benefits derived and hence this scale is relevant to the study. The Cronbach Alpha for EU was 0.68 and the Cronbach Alpha for FU was 0.73. These reliabilities are seen as weak but acceptable (Churchill, 1979). 


\begin{tabular}{|c|c|c|c|c|c|}
\hline \multicolumn{6}{|c|}{ Table 3-6-Scale for $\mathbf{E U}$ and FU } \\
\hline & $\begin{array}{l}\text { Strongly } \\
\text { disagree }\end{array}$ & & & & $\begin{array}{l}\text { Strongl } \\
\text { y agree }\end{array}$ \\
\hline \multicolumn{6}{|l|}{ Emotional utility } \\
\hline $\begin{array}{l}\text { 1.I often give to this non profit because I would feel guilty if I } \\
\text { didn't }\end{array}$ & 1 & 2 & 3 & 4 & 5 \\
\hline 2.If I never gave to this non profit I would feel bad about myself & 1 & 2 & 3 & 4 & 5 \\
\hline \multicolumn{6}{|l|}{ Familial Utility } \\
\hline 1.I give money to this non profit in memory of a loved one & 1 & 2 & 3 & 4 & 5 \\
\hline 2.I felt that someone I know might benefit from my support & 1 & 2 & 3 & 4 & 5 \\
\hline 3.My family had a strong link to this non profit & 1 & 2 & 3 & 4 & 5 \\
\hline
\end{tabular}

Source: Sargeant et al. (2006)

\section{Commitment}

Commitment is the enduring desire to maintain a valued relationship (Morgan and Hunt, 1994). The higher the emotional utility (emotions felt out of giving) and familial utility (link to family), the greater the degree of commitment and the greater the level of giving that is exhibited by the donor to that charitable organization (Sargeant et al., 2006). Commitment was measured using the four item scale developed by Morgan and Hunt (1994) and adapted by Sargeant et al. (2006) to a non profit context (Table 3-7). The scale demonstrated a reasonably good reliability $(\alpha=0.76)$.

\begin{tabular}{|l|c|c|c|c|c|}
\hline \multicolumn{7}{|c|}{ Table 3-7 - Commitment scale } & $\begin{array}{c}\text { Strongly } \\
\text { disagree }\end{array}$ & & & $\begin{array}{c}\text { Strongly } \\
\text { agree }\end{array}$ \\
\hline & 1 & 2 & 3 & 4 & 5 \\
\hline 1.I feel a sense of belonging to this organization & 1 & 2 & 3 & 4 & 5 \\
\hline 2.I care about the long term success of this organization & 1 & 2 & 3 & 4 & 5 \\
\hline $\begin{array}{l}\text { 3.I would describe myself as a loyal supporter of this } \\
\text { organization }\end{array}$ & 1 & 2 & 3 & 4 & 5 \\
\hline 4.I will be giving more to this non profit next year & 1 &
\end{tabular}

\section{Source: Morgan and Hunt (1994) and adapted by Sargeant et al. (2006)}

Age and Giving to charity

Age was determined by asking the respondents to mention the year of their birth. The intention to donate to the specific charity in the future was recorded. This was 
measured using the Ranganathan and Henley (2007) intention to donate scale. They adapted the Coyle and Thorson (2001) behavioral intention scale to the context of giving to charity. Ranganathan and Henley (2007) tested the four item intention to donate scale (Table 3-8) among 214 individuals and it showed good reliability $(\alpha=0.89)$.

\begin{tabular}{|l|l|c|c|c|c|c|}
\hline \multicolumn{7}{|c|}{ Table 3-8 - Intention to donate scale } \\
\hline \multicolumn{2}{|l|}{ Indicate how likely are you to agree / disagree with the following statements: } \\
\hline & $\begin{array}{c}\text { Completely } \\
\text { disagree }\end{array}$ & $\begin{array}{c}\text { Neither } \\
\text { agree } \\
\text { nor } \\
\text { disagree }\end{array}$ & $\begin{array}{c}\text { Completely } \\
\text { agree }\end{array}$ \\
\hline 1 & I am likely to donate to the charity in question & 1 & 2 & 3 & 4 & 5 \\
\hline 2 & I will donate the next time & 1 & 2 & 3 & 4 & 5 \\
\hline 3 & I will definitely donate & 1 & 2 & 3 & 4 & 5 \\
\hline 4 & $\begin{array}{l}\text { I will recommend the charity to others to } \\
\text { donate }\end{array}$ & 1 & 2 & 3 & 4 & 5 \\
\hline
\end{tabular}

Source: Ranganathan and Henley (2007)

\section{RESEARCH PROCESS}

\section{Data source}

Since this study aims at studying the personal nostalgia involved in giving to charity, data was collected from donors (those people who have donated money to charity in the last twelve months). In order to enhance generalizability of the findings a wide mix of demographic profile of the donors would be desirable. At the same time it would also be key to have a good mix in the type of charitable organization the money was donated to and the donation amount.

Keeping this in mind data was collected from members of a national on line consumer panel in the U.S. There has been increasing support of this technique of data collection in the academic literature. Braunsberger et al. (2007) found that survey data collected from an online consumer panel to be of good quality. They collected data from 
two waves of telephone surveys and web-panel surveys. They found that web panels can produce more reliable data estimates than telephone surveys. They also found that, web panels were cheaper and less time consuming to conduct than telephone surveys. They state that on line consumer panel surveys are a viable alternative that allow researchers to conduct high-quality research. Fielding (2007) recognizes web based consumer panels fór enabling researchers to leverage technology to collect data from a wide range and types of participants. This has also been supported by Punj (2006), who states that future researches that use structural equations modeling, may use on line consumer panels for data collection. Recently, Bosnjak et al. (2007) used on line consumer panel to study the personality determinants of purchase intentions.

Issues and Answers Research Agency was briefed to collect data from their on line consumer panel from those individuals who had donated to charity in the last twelve months. The research agency was asked to get a good mix of respondents across demographic profiles as well as type of organization the money was donated to. To maintain the quality of data the research agency was asked to constantly monitor the data to ensure that the profile requirements were met and that there were no incomplete surveys. A sample of 500 completed surveys was targeted.

\section{Analysis}

Data was analyzed using SPSS and AMOS. The following steps were followed :

Step 1 : Sample profile

The sample was profiled for age, sex, race, education and income. This analysis would help confirm that the data was not skewed. The sample was also analyzed for donation behavior. The amount donated, the type of charitable organization donated to and the 
frequency of donation to the concerned charitable organization was to be examined. This helped reconfirm that the data had a good spread and thus the findings would be generalizable to the population.

Step 2: Measurement model

Confirmatory factor analysis (CFA) was then conducted for the various constructs using AMOS. At first CFA for individual constructs was conducted which was followed by a CFA for all the constructs together. Those items which had a low loading were dropped. Modification indices were run and those items with a modification index more than 20 were also dropped. The fit of the model was also examined. Reliability was for the latent constructs were determined using Cronbach's alpha (in SPSS).

Step 3: Structural model

Once the measurement model was found to be satisfactory, structural equation modeling was conducted using AMOS. The model fit indices were analyzed along with the variance explained for the endogenous constructs. The regression weights for the hypothesized links were tested for statistical significance.

Step 4 : Data Summarizing

The results of the profile analysis, the final list of scale items with the standardized loadings, the fit indices of the measurement model, the standardized weights and statistical significance of the links in structural model and the fit indices of the structural model were summarized in the form of tables.

In chapter four a detailed discussion on the questionnaire design and data collection will be presented. The profile of the respondents will be examined, along with a detailed note on the steps followed for studying the measurement model. The results of 
the CFA will be discussed and the structural model and hypothesis tests will also be presented. An alternate model will be discussed and key findings will be analyzed. 


\section{CHAPTER 4: RESULTS OF THE STUDY}

\section{INTRODUCTION}

This chapter will present the findings of the study. There will first be a discussion of the questionnaire and its development, followed by a note on the process involved in the data collection. Then the profile of the respondents in the survey will be discussed. This will be followed with the findings of the confirmatory factor analysis and the structural equation model. Lastly, the results of the hypothesis testing will be presented.

\section{DATA COLLECTION}

\section{Questionnaire Design}

The questionnaire was developed using the scales presented in chapter 3. In order to strengthen the measures additional questions were added to two of the scales Emotional Utility and Recovery from Grief. The following statements were added to the Emotional Utility scale (Sargeant et al., 2007): "I felt happy when I gave money to this charitable organization" and "I felt good when I gave money to this charitable organization". These statements were added to help capture the positive emotional benefits derived by the donor by giving to charity. The following statements were added to the Recovery from Grief scale (Carnelly et al., 2006): "When you think about your late friend or relative how happy do you feel?" and "When you think about your late friend or relative how sad do you feel?". These two questions were aimed at capturing the depth of the positive and negative emotions experienced while remembering a deceased friend /relative.

Additionally questions were added to record the demographic details of the respondent as well as details of the charitable donation the respondent had made. The demographic 
questions included the respondent's race, sex, education qualification and the annual household income. Details of the respondent's most recent charitable gift were also solicited. The respondent was asked to furnish information such as the type of charitable organization he or she last donated money to, how many times in the past they had donated and which type of charitable organization he or she regularly donated money to (Please see Appendix A for the questionnaire).

\section{Data collection process}

Issues and Answers Research Agency (Virginia Beach) was contacted to collect data from an online consumer panel. They were asked to supply 500 completed surveys from U.S. consumers who had donated money to a charitable organization in the last twelve months. Their online consumer panel contained 16,000 members. This panel was constructed and selected in line with the U.S. census. The research agency utilized the following process for data collection. The total panel universe was divided by the required sample size to create a selection interval. Every nth record was selected according to the selection interval. Once the end of the universe was reached, the computer program used by them went back to the beginning for additional records to fulfill the needed sample size. The resulting target sample was sorted randomly before emailing, using a standard Oracle random sorting algorithm. When samples were emailed, each batch represented a mini version of the entire sample, virtually identical in demographics, geography, etc. to every other batch. For the current project 905 respondents answered the first question and then $505(56 \%)$ qualified as having donated to charity in the last 12 months and continued the entire survey (3 respondents were removed from the data for having missing values). The invitations to participate in the 
study were sent to: an even split of males and females, 18 years and older, mostly with $\$ 30 \mathrm{~K}+$ household income, representing a national geographic spread. The agency returned completed responses from 502 consumers who had donated money to charity in the last 12 months. The data was received in SPSS format.

\section{Profile of the respondents}

The data were checked for any inconsistencies. Frequencies for every third scale item were analyzed. The check indicated that there were no major issues and the data appeared balanced. The data was also eyeballed for any issues on the respondent's demographic profile. The initial analysis showed that there were no major issues.

A detailed analysis of the respondents showed that there was a balanced age break down on age (see Table 4-1). The average age of the respondents was 51 years. All income groups were represented in the sample (see Table 4-2). There was also a balance between male and female respondents (Table 4-3). The racial profile of the respondents was skewed more towards Caucasians (Table 4-4). The respondents in the sample were educated, $84 \%$ having done some college education or more (Table $4-5$ ). The balanced demographic profile of the sample was encouraging as it enhances the generalizability of the study findings.

\begin{tabular}{|c|c|}
\hline \multicolumn{2}{|c|}{ Table 4-1 } \\
\hline \multicolumn{2}{|c|}{ Age of the respondents } \\
\hline Age & Percentage \\
\hline 18-30 Years & 8.0 \\
\hline 31-40 Years & 14.0 \\
\hline 41-50 Years & 22.0 \\
\hline 51-60 Years & 32.0 \\
\hline Over 61 Years & 24.0 \\
\hline & \\
\hline Mean age- \\
51 years
\end{tabular}




\begin{tabular}{|c|c|}
\hline \multicolumn{2}{|l|}{ Table 4-2 } \\
\hline \multicolumn{2}{|c|}{$\begin{array}{l}\text { Annual household income of the } \\
\text { respondents }\end{array}$} \\
\hline Income & Percentage \\
\hline Less than $\$ 25,000$ per year & 3.0 \\
\hline$\$ 25,000-\$ 49,999$ per year & 24.5 \\
\hline$\$ 50,000-\$ 74,999$ per year & 28.3 \\
\hline$\$ 75,000-\$ 99,999$ per year & 19.3 \\
\hline$\$ 100,000-\$ 149,999$ & 12.7 \\
\hline$\$ 150,000-\$ 199,999$ & 4.4 \\
\hline Over $\$ 200,000$ per year & 2.0 \\
\hline Undisclosed & 5.8 \\
\hline
\end{tabular}

Table 4-3

\begin{tabular}{|l|c|}
\hline \multicolumn{2}{|c|}{ Table 4-3 } \\
\hline \multicolumn{2}{|c|}{ Sex of the respondents } \\
\hline & Percentage \\
\hline Male & 49.0 \\
\hline Female & 50.4 \\
\hline Undisclosed & 0.6 \\
\hline
\end{tabular}

\begin{tabular}{|c|c|}
\hline \multirow{2}{*}{\multicolumn{2}{|c|}{$\begin{array}{c}\text { Table 4-4 } \\
\begin{array}{l}\text { Racial background of the } \\
\text { respondents }\end{array}\end{array}$}} \\
\hline & \\
\hline Racial Background & Percentage \\
\hline African American & 3.0 \\
\hline Caucasian & 87.6 \\
\hline Hispanic & 2.4 \\
\hline Native-American & 1.2 \\
\hline Other & 3.2 \\
\hline Undisclosed & 2.6 \\
\hline
\end{tabular}

Table 4-5

\begin{tabular}{|l|c|}
\hline \multicolumn{2}{|c|}{ Table 4-5 } \\
\hline \multicolumn{2}{|c|}{ Education level of the respondents } \\
\hline \multicolumn{1}{|c|}{ Education Level } & Percentage \\
\hline Some school & 0.4 \\
\hline High school completed & 15.6 \\
\hline Some college & 32.5 \\
\hline College graduate & 27.9 \\
\hline Some post graduate & 7.8 \\
\hline Post graduate completed & 11.2 \\
\hline Some doctoral & 1.4 \\
\hline Doctorate completed & 2.4 \\
\hline Undisclosed & 0.8 \\
\hline
\end{tabular}


When examining the charitable donation recipients, $38.3 \%$ of the respondents had donated to Church and Religious organizations. This was followed by humanitarian organizations (22.9\%) like Red Cross and United Way. 16.3\% had donated to hospitals and $17.7 \%$ of the respondents had donated to environment and police/military related charities. In summary, there was a good mix of charitable organizations represented in the sample (Table 4-6). There was also a good spread in the amount of money donated (Table 4-7). The median gift amount was $\$ 40$, with $46 \%$ of the respondents indicating donations of less than $\$ 25$ and $14 \%$ with relatively large amounts (more than $\$ 150$ ). In terms of the number of times the respondents had donated to that charitable organization, $77.7 \%$ of the respondents in the sample indicated that they had given to that charitable organization over four times ever before (Table 4-8). This implies that they had a relationship with the charitable organization. Lastly, the respondents had made their last donations relatively recently. In fact $70.9 \%$ of the respondents had made their donations less than three months ago (Table 4-9). This mix of charitable organizations and gift size also enhances the generalizability of the study findings.

\begin{tabular}{|l|c|}
\hline \multicolumn{2}{|c|}{ Table 4-6 } \\
\hline \multicolumn{2}{|c|}{ Type of charitable organization last donated } \\
\hline \multicolumn{1}{|c|}{ Type } & Percentage \\
\hline Church/ Religious organization & 38.3 \\
\hline Hospital/Medical organization & 16.3 \\
\hline Academic institution & 3.2 \\
\hline Humanitarian organization & 22.9 \\
\hline Arts organization & 1.6 \\
\hline $\begin{array}{l}\text { Others (E.G. Environment, police } \\
\text { etc) }\end{array}$ & 17.7 \\
\hline
\end{tabular}




\begin{tabular}{|c|c|}
\hline \multicolumn{2}{|c|}{ Table 4-7 } \\
\hline \multicolumn{2}{|c|}{ Amount last donated } \\
\hline Gift amount & Percentage \\
\hline Less than $\$ 25$ & 46.0 \\
\hline$\$ 26-\$ 50$ & 21.0 \\
\hline$\$ 51-\$ 75$ & 4.0 \\
\hline$\$ 76-\$ 100$ & 12.0 \\
\hline$\$ 101-\$ 125$ & 1.0 \\
\hline$\$ 126-\$ 150$ & 2.0 \\
\hline Over $\$ 150$ & 14.0 \\
\hline Median: $\$$ & \\
\hline
\end{tabular}

\begin{tabular}{|l|c|}
\hline \multicolumn{2}{|c|}{ Table 4-8 } \\
\hline \multicolumn{2}{|c|}{ How many times EVER donated to the charitable } \\
organization
\end{tabular}

\begin{tabular}{|l|c|}
\hline \multicolumn{2}{|c|}{ Table 4-9 } \\
\hline \multicolumn{2}{|c|}{ When last donated } \\
\hline \multicolumn{1}{|c|}{ When last donated } & Percentage \\
\hline Within the last week & 23.5 \\
\hline Within the last month & 24.7 \\
\hline Last three months & 22.7 \\
\hline Last six months & 11.8 \\
\hline $\begin{array}{l}\text { Six months to twelve } \\
\text { months }\end{array}$ & 17.3 \\
\hline
\end{tabular}

\section{DATA ANALYSIS}

Before the data were analyzed some of the measures needed to be refined. Age was calculated by subtracting the year of birth from the current calendar year (2008). In order to capture the magnitude of discontinuity faced by each respondent, the absolute discontinuity impact for each of the respondents across all the items of discontinuity were 
added. Thus, a single measure of discontinuity was arrived at. Ten items of the loneliness scale were reversed coded.

\section{Measurement Model}

At first the reliabilities (Cronbach's Alpha) of each of the latent constructs were calculated in SPSS. Opportunities for improving the reliability were evaluated by looking at the analysis of the improvements in Cronbach's Alpha if any item were deleted. However, none of the items were dropped at this juncture. A confirmatory factor analysis was conducted across the eight latent constructs using AMOS 5.0. The standardized regression weights were studied and a note was made of all the items that had a standardized loading less than 0.45 . Modification indices were also run. Those error terms which had a high covariance (modification index $>20$ ) with other error terms were identified and noted. However, at this juncture no items were deleted from any of the scales.

In order to evaluate the measurement properties of the endogenous and exogenous variables used in the study, a confirmatory factor analysis model was estimated (using AMOS 5.0) with all the scales for the eight latent constructs (Anderson and Gerbing, 1988), measured using 63 items - Personal Nostalgia (20 items), Loneliness (20 items), Recovery from Grief (4 items), Intention to Donate (4 items), Commitment (4 items), Emotional Utility (4 items), Familial Utility (3 items) and Past Experiences associated with the NPO (2 items).

In terms of the validity of the measures, convergent validity is indicated by large and significant standardized loadings of the constructs on their posited indicators (Anderson and Gerbing, 1988). In this analysis, loadings with standardized factor 
loading greater than 0.45 were assessed to have good convergent validity, and were retained. After deleting items with loading less than 0.45 , the fit was re-assessed. Modification indices were run for the error terms of the items. Items which had an error term with a modification index more than 20 were deleted (see Table 4-10 for the items retained and their factor loadings and Appendix B for the scale items that were deleted).

As shown in Table 4-10, the measurement model demonstrates reasonable levels of fit $\left(\chi^{2}(674)=1228, \chi 2 / \mathrm{df}=1.82, \mathrm{CFI}=0.94, \mathrm{IFI}=0.94, \mathrm{TLI}=0.94, \mathrm{GFI}=0.89\right.$, RMSEA $=0.041)$ to the data. As pointed out by Hair et al. (2006), the cut-off values of the fit indices should be adjusted based upon sample size, model complexity, and degrees of freedom in model specification to examine how accurately various fit indices performed. They recommend that simpler models and smaller samples should be subject to a stricter evaluation than more complex models with larger samples. Based on the guidance that they provide, for sample sizes greater than 250 , and the number of observed variables greater than 30, CFI, TLI and IFI should be above 0.90 , and RMSEA $<0.07$ with CFI of 0.90 or higher. Bollen (1989) and Bentler (1992) also state that CFI, TLI and IFI over 0.90 are considered acceptable for complex models. Hu and Bentler (1999) suggest that RMSEA values of 0.06 or less are indicative of a good fit between the hypothesized model and the observed data. Based on these criteria, the model fit for the complete measurement model is deemed to be acceptable. Reliability measures the degree to which the indicators represent the construct (Table 4-10). Reliability was assessed using the Cronbach's Alpha coefficient. All the constructs had acceptable Alpha coefficient (E.g. Personal Nostalgia - 0.88, Emotional Utility - 0.88, Intention To Donate - 0.90, Loneliness -0.89 , Commitment -0.82 , Recovery from Grief -0.85 etc). The only 
construct which had a relatively low reliability was Familial Utility $(\alpha=0.61)$. Additional analysis was run for the increase/decrease in the Cronbach's Alpha if any of the scale items were dropped for the items of familial utility. The analysis showed that there was no opportunity to increase the alpha as there was a drop in the alpha if any of the items were dropped. 
in

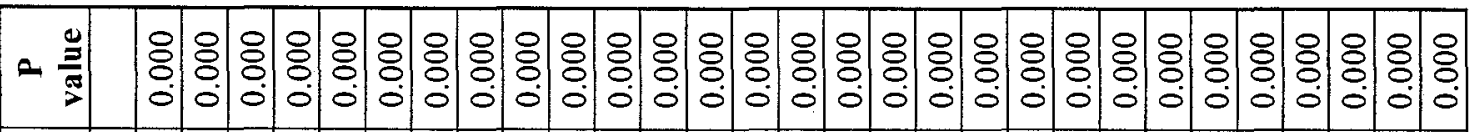

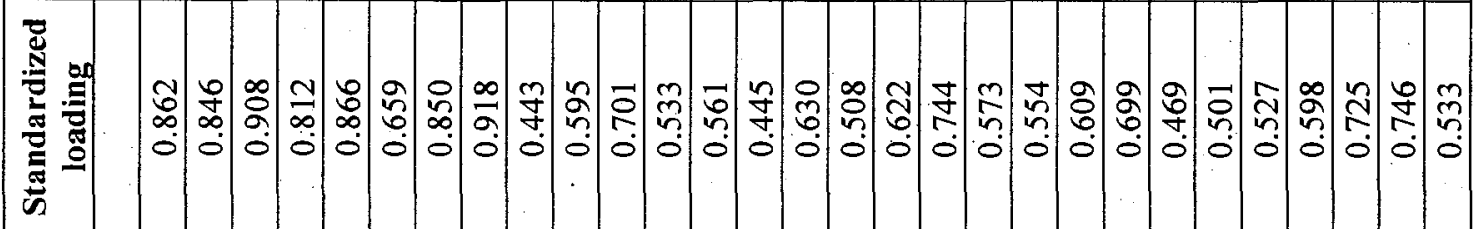

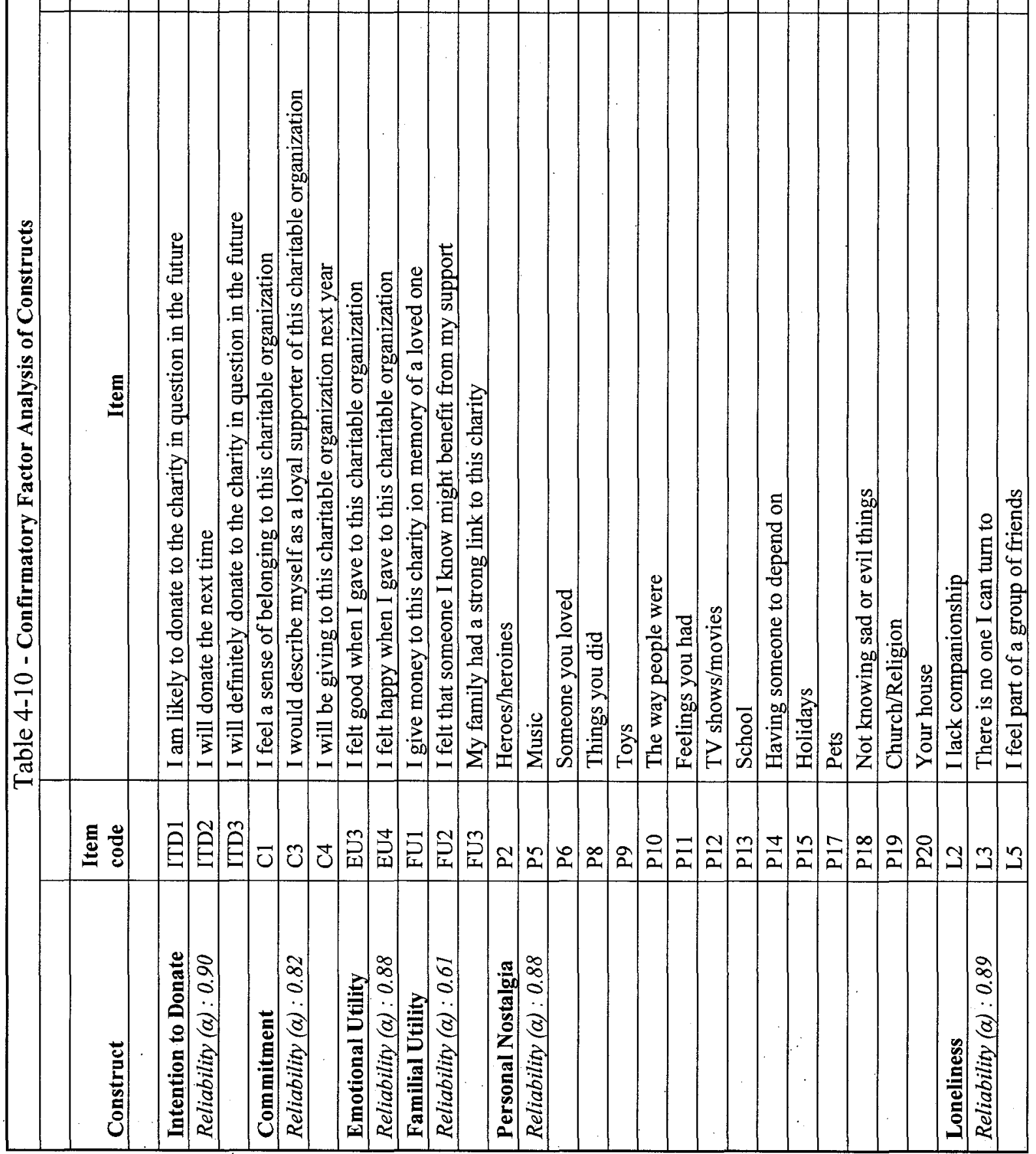


8

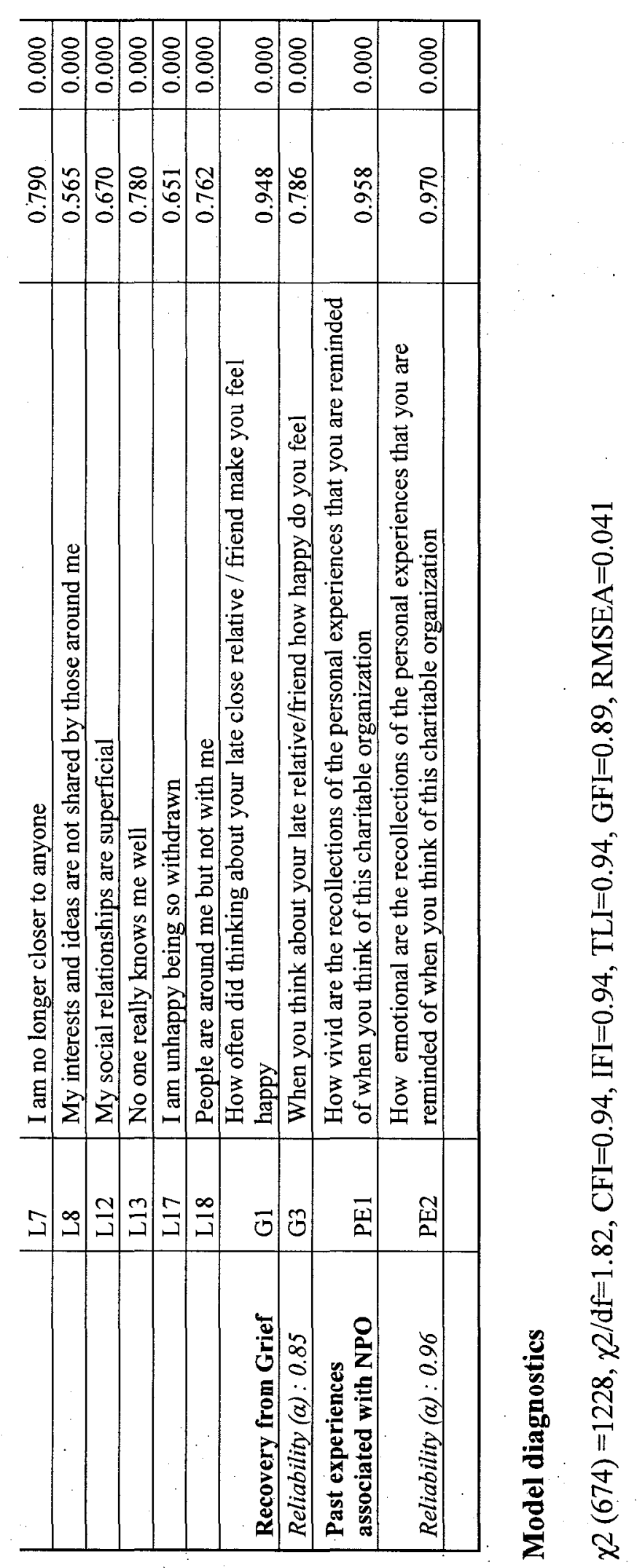




\section{Structural Model and Hypothesis Testing}

After fine tuning the measurement model, the two single item constructs - age and discontinuity were added to the model. Table 4-11 shows the correlations among the latent constructs. The structural paths were defined as per the conceptual model in chapter two. Structural equation modeling was run using AMOS 5.0. Figure 4-2 (also see Table 4-12) is a pictorial depiction of the structural model. The structural model shows reasonably good fit $\left(\chi^{2}(771)=1626, \chi^{2} / \mathrm{df}=2.10, \mathrm{CFI}=0.91, \mathrm{IFI}=0.91, \mathrm{TLI}=0.91\right.$, $\mathrm{GFI}=0.86$, RMSEA=0.047). Based on the criteria recommended by Hair et al. (2006), Bollen (1989) and $\mathrm{Hu}$ and Bentler (1999) (discussed earlier) it is argued that the measures of the fit are acceptable.

Figure 4-1 - Structural Model: Results

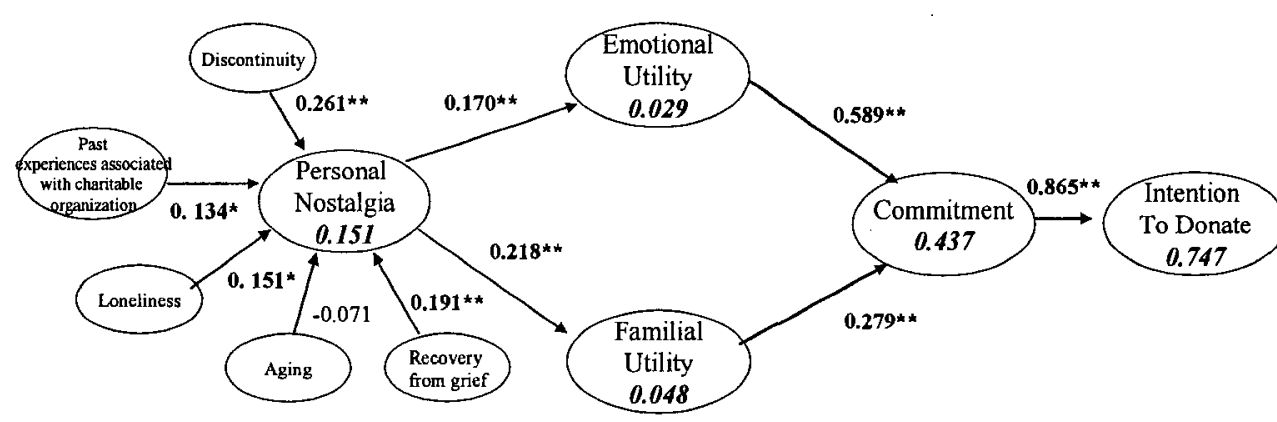

Model diagnostics

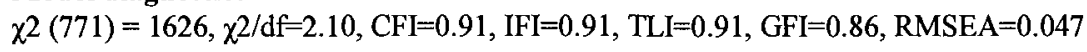

**Standardized estimates significant at $p<0.001$, *Standardized estimates significant at $p<0.01$

Figures in italics are the squared correlations for the endogenous constructs

The key constructs were assessed in terms of the squared correlations to assess the amount of variance explained by each of the construct modeling (see Table 4-13). As per 
Cohen (1992), in models using multiple independent variables, an effect size of $2 \%$ is considered small, around $15 \%$ is considered medium and $35 \%$ or more is considered large. This model explains $15.1 \%$ of the variance in personal nostalgia. Thus it means that the variance exogenous variables (such as discontinuity, aging, loneliness etc) that lead to personal nostalgia together explain $15.1 \%$ of the variance of personal nostalgia. Since, the primary objective of this study is not to explain all the variables that influence personal nostalgia this is medium and acceptable. This also means that there are a host of other factors that influence personal nostalgia which have not been modeled in this study and can be opportunities of future researches in this area. This model explains $2.9 \%$ of the variance in emotional utility and $4.8 \%$ of the variance of familial utility, which are both small. The scope of this study is to model the emotional utility derived out of personal nostalgia. Since both the constructs (EU and FU) are extremely complex and are influenced by a multiple other psychological constructs the variance explained can be considered acceptable. Finally, this model explains $43.7 \%$ of the variance of commitment and $74.7 \%$ of the variance in the intention to donate, which are both large. This means that the variance exogenous variables (like discontinuity, aging, loneliness etc.) and endogenous variables (like personal nostalgia, $\mathrm{EU}$ and $\mathrm{FU}$ ) in this model explain a reasonably large amount of the variance of Commitment and Intention to Donate which are the key dependent variables of this study. The fit looks reasonably good, and we can say that the model does a reasonably good job explaining, so the indications are that the model performs satisfactorily.

Table 4-12 provides a summary of the hypothesis tests. The hypotheses were tested using the path coefficient. 
Hypothesis 1: This states that there is a positive causal link between Discontinuity and Personal Nostalgia. The path coefficient $=0.261,(t=5.462)$ is significant at $p<0.001$ (see Table 4-12). Therefore, $\mathrm{H} 1$ is supported. As hypothesized, this means that as individuals experience discontinuity they are likely to get nostalgic for the past, as the past gives them a sense of security. This finding builds on the work of Mehta and Belk (1991) and Belk (1990) who had studied this relationship qualitatively.

Hypothesis 2: This hypothesis states that there is a positive causal link between Past experiences associated with NPO and Personal Nostalgia. The path coefficient $=0.134$, $(\mathrm{t}=2.698)$ is also significant at $\mathrm{p}<0.01$ and thus hypothesis 2 is supported (see Table 412). As hypothesized, it means that individuals tend to get nostalgic about past experiences associated with the charitable organization. Therefore for an NPO to evoke personal nostalgia it must ensure that the donors have fond memories linked to the NPO. Hypothesis 3: The findings of this study confirmed that loneliness has a significant impact on Personal Nostalgia The path coefficient $=0.151,(t=3.148)$ is significant at $\mathrm{p}<0.01$. Therefore, hypothesis 3 is supported. This implies that as individuals get lonely they tend to think of the past and tend to get nostalgic and fondly remember the days of the past.

Hypothesis 4: Contrary to what was hypothesized, this study found that Aging does not have a significant impact on Personal Nostalgia, hence hypothesis 4 is not supported. Hypothesis 5: As hypothesized, this study found that Recovery from Grief does have a significant and positive impact on Personal Nostalgia (Table 4-12) The path coefficient $=0.191,(t=3.338)$ is significant at $p<0.001$ and thus hypothesis 5 is supported. This supports the arguments made by this study that when remembering the deceased friend or 
relative, individuals get nostalgic about the times they have spent with the deceased loved one. As people cope with the death of a loved one they seek solace in the memories of the deceased and get nostalgic for the days spent with the deceased. This finding is significant as a review of the literature did not find any prior research which had looked at this relationship and tested it empirically.

Hypotheses 6 and 7: Both these hypotheses are supported as there is a significant causal link between Personal Nostalgia and Emotional Utility (path coefficient $=0.218, \mathrm{t}=3.611$ ) is significant at $\mathrm{p}<0.001$ ) and Personal Nostalgia and Familial Utility (path coefficient $=$ $0.170, \mathrm{t}=3.314)$ is significant at $\mathrm{p}<0.001)$. Thus, as argued in chapter three, personal nostalgia results in emotional benefits for the donor. This finding is key as it confirms that even in the charitable giving context personal nostalgia results in emotional engagement with the donors.

Hypothesis 8 and 9: These two hypotheses posited a positive causal link between Emotional Utility and Commitment (path coefficient $=0.589, \mathrm{t}=10.461$ ) and Familial Utility and Commitment (path coefficient $=0.279, t=4.897$ ) (see Table 4-12). The coefficients of both these paths are significant at $p<0.001$ and hence Familial Utility and Emotional Utility have a significant impact on Commitment of the donor, hence hypotheses 8 and 9 are also supported. This means that the emotional utility and the familial utility that the donor derives out of the personal nostalgia associated with the charitable organization results in higher levels of commitment the donor has to the charitable organization.

Hypothesis 10: It was argued that the Commitment of the donor results in Intention to Donate. As per Table 4-12, this path coefficient $=0.865$, $(t=14.079)$ is significant at 
$\mathrm{p}<0.001$. Hence we can say that as the Commitment to the NPO increases the Intention to

Donate to the NPO also increases.

Table 4-11 - Correlations among latent constructs

\begin{tabular}{|c|c|c|c|c|c|c|c|c|c|c|}
\hline & 1 & 2 & 3 & 4 & 5 & 6 & 7 & 8 & 9 & 10 \\
\hline $\begin{array}{l}\text { INTENTION TO } \\
\text { DONATE }\end{array}$ & 1 & & & & & & & & & \\
\hline COMMITMENT & $.759 * *$ & 1 & & & & & & & & \\
\hline $\begin{array}{l}\text { EMOTIONAL } \\
\text { UTILITY }\end{array}$ & $.536^{* *}$ & $.559^{* *}$ & 1 & & & & & & & \\
\hline $\begin{array}{l}\text { FAMILIAL } \\
\text { UTILITY }\end{array}$ & $.228^{* *}$ & $.379^{* *}$ & $.296^{* *}$ & 1 & & & & & & \\
\hline $\begin{array}{l}\text { PERSONAL } \\
\text { NOSTALGIA }\end{array}$ & .016 & .050 & $.147^{* *}$ & $.187^{* *}$ & 1 & & & & & \\
\hline $\begin{array}{l}\text { GRIEF } \\
\text { RECOVERY }\end{array}$ & $.173^{* *}$ & $.133^{* *}$ & $.190^{* *}$ & $.142^{* *}$ & $.187^{* *}$ & 1 & & . & & \\
\hline LONELINESS & $-.191^{* *}$ & $-.164^{* *}$ & $-.096^{*}$ & -.047 & $.176^{* *}$ & $-.173 * *$ & 1 & & & \\
\hline $\begin{array}{l}\text { PAST } \\
\text { EXPERIENCES }\end{array}$ & $.136^{* *}$ & $.153^{* *}$ & $.163^{* *}$ & $.298^{* *}$ & $.176^{* *}$ & $.133^{* *}$ & .044 & 1 & & \\
\hline DISCONTINUITY & .084 & .072 & $.189^{* *}$ & .080 & $.330^{* *}$ & $.111^{*}$ & $.267^{* *}$ & $.172^{* *}$ & 1 & \\
\hline AGING & $.110^{*}$ & $.107^{*}$ & .045 & .044 & $-.126^{* *}$ & -.021 & -.083 & .083 & $-.171^{* *}$ & 1 \\
\hline
\end{tabular}

Table 4-12-Structural Model Results and Hypotheses Tests (Full Model)

\begin{tabular}{|l|c|c|c|c|}
\hline & & & \\
\hline Path in the Model & Hypothesis & $\begin{array}{c}\text { Standardized } \\
\text { Estimate }\end{array}$ & t value & \\
\hline Exogenous-Endogenous Variables & & & & \\
\hline Discontinuity $\rightarrow$ Personal Nostalgia & $\mathrm{H} 1$ & 0.261 & $5.462^{* *}$ & \\
\hline $\begin{array}{l}\text { Past experiences with NPO } \rightarrow \text { Personal } \\
\text { Nostalgia }\end{array}$ & $\mathrm{H} 2$ & 0.134 & $2.698^{*}$ & \\
\hline Loneliness $\rightarrow$ Personal Nostalgia & $\mathrm{H} 3$ & 0.151 & $3.148^{*}$ & \\
\hline Aging $\rightarrow$ Personal Nostalgia & $\mathrm{H} 4$ & -0.071 & -1.585 & \\
\hline $\begin{array}{l}\text { Recovery from Grief } \rightarrow \text { Personal } \\
\text { Nostalgia }\end{array}$ & $\mathrm{H} 5$ & 0.191 & $3.338^{* *}$ & \\
\hline & & & & \\
\hline Between Endogenous Variables & & & & \\
\hline Personal Nostalgia $\rightarrow$ Familial Utility & $\mathrm{H} 6$ & 0.218 & $3.611^{* *}$ & \\
\hline $\begin{array}{l}\text { Personal Nostalgia } \rightarrow \text { Emotional } \\
\text { Utility }\end{array}$ & $\mathrm{H} 7$ & 0.170 & $3.314^{* *}$ & \\
\hline Familial Utility $\rightarrow$ Commitment & $\mathrm{H} 8$ & 0.279 & $4.897^{* *}$ & \\
\hline Emotional Utility $\rightarrow$ Commitment & $\mathrm{H} 9$ & 0.589 & $10.461^{* *}$ & \\
\hline Commitment $\rightarrow$ Intention to donate & $\mathrm{H} 10$ & 0.865 & $14.079^{* *}$ & \\
\hline
\end{tabular}




\begin{tabular}{|l|l|l|l|} 
& & & \\
\hline Model diagnostics & & & \\
\hline$\chi 2(771)=1626, \chi 2 / \mathrm{df}=2.10$, & & \\
$\mathrm{CFI}=0.91, \mathrm{IFI}=0.91, \mathrm{TLI}=0.91$, & & $\begin{array}{c}* \text { significant at } \\
p<0.001\end{array}$ & $\begin{array}{c}* \text { significant } \\
\text { at } p<0.01\end{array}$ \\
$\mathrm{GFI}=0.86, \mathrm{RMSEA}=0.047$ & & \\
\hline
\end{tabular}

\begin{tabular}{|l|c|}
\hline \multicolumn{2}{|c|}{$\begin{array}{c}\text { Table 4-13 - Variance Explained of Endogenous } \\
\text { Constructs }\end{array}$} \\
\hline Endogenous Construct & $\begin{array}{c}\text { Squared } \\
\text { Correlations }\end{array}$ \\
\hline Personal Nostalgia & 0.151 \\
\hline Emotional Utility & 0.029 \\
\hline Familial Utility & 0.048 \\
\hline Commitment & 0.437 \\
\hline Intention To Donate & 0.747 \\
\hline
\end{tabular}

\section{Structural Model without Aging and Discontinuity}

One likely criticism of this structural model could be that it has two single item exogenous constructs (Aging and Discontinuity). To retest the robustness of the model both these single item constructs were eliminated from the structural model. The revised model with eight latent constructs was then run. The results of this model are found in Table 4-14. The structural model shows reasonably good fit $(\chi 2(694)=1410$, $\chi 2 / \mathrm{df}=2.03, \mathrm{CFI}=0.92, \mathrm{IFI}=0.93, \mathrm{TLI}=0.92, \mathrm{GFI}=0.87, \mathrm{RMSEA}=0.045)$.

Since two of the influences of personal nostalgia were eliminated, there is a decline in the variance explained. The model now explains only $12.9 \%$ of the variance in personal nostalgia (see Table 4-15). The other endogenous constructs were impacted less significantly: The model now explains $2.9 \%$ of the variance in emotional utility, $5 \%$ of the variance of familial utility, $43.8 \%$ of the variance of commitment and $74.8 \%$ of the variance in the intention to donate. Since the key dependents constructs of this study are 
Commitment and Intention to Donate the model does a good job of explaining a large amount of their variance and therefore it is acceptable.

Table 4-14 provides a summary of the hypothesis tests.. The hypotheses were tested using the path coefficient. Hypotheses 1 and 4 are not tested in this current model as they are concerned with the relationship between Aging and Personal Nostalgia and Discontinuity and Personal Nostalgia, both of these exogenous constructs were excluded in this current analysis.

Hypothesis 2: This hypothesis states that there is a positive causal link between past experiences associated with NPO and Personal Nostalgia. The path coefficient $=0.159$, $(\mathrm{t}=3.154)$ is also significant at $\mathrm{p}<0.01$ and thus hypothesis 2 is supported (see Table 414). As hypothesized, this means that individuals tend to get nostalgic about past experiences associated with the charitable organization.

Hypothesis 3: The findings of this study confirmed that loneliness has a significant impact on Personal Nostalgia (path coefficient $=0.227, \mathrm{t}=4.508, \mathrm{p}<0.001$ ). Therefore, hypothesis 3 is supported. This implies that as individuals get lonely they tend to think of the past and tend to get nostalgic.

Hypothesis 5: As hypothesized, this study found that Recovery from Grief does have a significant and positive impact on Personal Nostalgia (Table 4-14) and thus hypothesis 5 is supported (path coefficient $=0.228, \mathrm{t}=3.926, \mathrm{p}<0.001$ ). This supports the arguments made by this study that when remembering the deceased friend or relative, individuals get nostalgic about the times they have spent with the deceased loved one.

Hypotheses 6 and 7: Both these hypotheses are supported as there is a significant causal link between Personal Nostalgia and Emotional Utility (path coefficient $=0.170, t=3.326$, 
$p<0.001$ ) and Personal Nostalgia and Familial Utility (path coefficient $=0.225, t=3.729$, $\mathrm{p}<0.001)$. Thus, as argued in chapter three, personal nostalgia results in emotional benefits for the donor.

Hypothesis 8 and 9: These two hypotheses posited a positive causal link between Emotional Utility and Commitment (path coefficient $=0.590, \mathrm{t}=10.472$ ), and Familial Utility and Commitment (path coefficient $=0.279, t=4.910$ ). The coefficients of both these paths are significant at $p<0.001$ and hence Familial Utility and Emotional Utility have a significant impact on Commitment of the donor, hence hypotheses 8 and 9 are also supported. This means that the emotional utility and the familial utility that the donor derives out of the personal nostalgia associated with the charitable organization results in higher levels of commitment the donor has to the charitable organization.

Hypothesis 10: It was argued that the Commitment of the donor results in Intention to Donate. As per Table 4-14 this path coefficient $=0.865,(t=14.089)$ is also significant at $\mathrm{p}<0.001$. Hence we can say that as the Commitment to the NPO increases the Intention to Donate to the NPO also increases.

\begin{tabular}{|l|l|c|c|c|}
\hline $\begin{array}{l}\text { Table 4-14 - Structural Model Results and Hypotheses Tests (without Aging and } \\
\text { Discontinuity) }\end{array}$ & & & & \\
\hline & Hypothesis & $\begin{array}{l}\text { Standardized } \\
\text { Estimate }\end{array}$ & t value & \\
\hline Path in the Model & & & & \\
\hline Exogenous-Endogenous Variables & $\mathrm{H} 2$ & 0.159 & $3.154^{*}$ & \\
\hline $\begin{array}{l}\text { Past experiences with NPO } \rightarrow \text { Personal } \\
\text { Nostalgia }\end{array}$ & $\mathrm{H} 3$ & 0.227 & $4.508^{* *}$ & \\
\hline Loneliness $\rightarrow$ Personal Nostalgia & $\mathrm{H} 5$ & 0.228 & $3.926^{* *}$ & \\
\hline $\begin{array}{l}\text { Recovery from Grief } \rightarrow \text { Personal } \\
\text { Nostalgia }\end{array}$ & & & & \\
\hline & & & & \\
\hline Between Endogenous Variables & $\mathrm{H} 6$ & 0.225 & $3.729^{* *}$ & \\
\hline Personal Nostalgia $\rightarrow$ Familial Utility & $\mathrm{H} 7$ & 0.170 & $3.326^{* *}$ &. \\
\hline Personal Nostalgia $\rightarrow$ Emotional Utility & & & &
\end{tabular}




\begin{tabular}{|l|c|c|c|c|} 
Familial Utility $\rightarrow$ Commitment & $\mathrm{H} 8$ & 0.279 & $4.910^{* *}$ & \\
\hline Emotional Utility $\rightarrow$ Commitment & $\mathrm{H} 9$ & 0.590 & $10.472^{* *}$ & \\
\hline Commitment $\rightarrow$ Intention to donate & $\mathrm{H} 10$ & 0.865 & $14.089 * *$ & \\
\hline & & & & $\vdots$ \\
\hline Model diagnostics & & & & \\
$\chi 2(694)=1410, \chi 2 / \mathrm{df}=2.03, \mathrm{CFI}=0.92$, & & & \\
$\mathrm{IFI}=0.93, \mathrm{TLI}=0.92, \mathrm{GFI}=0.87$, & & $\begin{array}{c}* * \text { significant at } \\
p<0.001\end{array}$ & $\begin{array}{c}* \text { significant } \\
\text { at } p<0.01\end{array}$ & \\
$\mathrm{RMSEA}=0.045$ & & &
\end{tabular}

\begin{tabular}{|l|c|}
\hline \multicolumn{2}{|c|}{$\begin{array}{c}\text { Table 4-15 - Variance Explained of Endogenous } \\
\text { Constructs (without Aging and Discontinuity) }\end{array}$} \\
\hline Endogenous Construct & $\begin{array}{c}\text { Squared } \\
\text { Correlations }\end{array}$ \\
\hline Personal Nostalgia & 0.129 \\
\hline Emotional Utility & 0.029 \\
\hline Familial Utility & 0.05 \\
\hline Commitment & 0.438 \\
\hline Intention To Donate & 0.748 \\
\hline
\end{tabular}

The next chapter will focus on the theoretical and managerial implications of this research. A discussion on the limitations of this study and some thoughts on what future researches could focus on in the area of Nostalgia and Charitable Giving will also be presented. 


\section{CHAPTER 5: CONCLUSIONS AND RECOMMENDATIONS}

\section{INTRODUCTION}

This chapter will discuss the key findings of the study. Theoretical contribution will also be presented along with a series of managerial implications. This will be followed by a discussion of the limitations of the study and suggestions for future researches.

\section{SUMMARY OF FINDINGS}

This research has found that fife stage factors like: the discontinuity the donor is experiencing, the extent to which the donor is feeling lonely, recovering from grief, along with whether the donor has significant past experiences associated with the charity influence the donor's personal nostalgia. The donor's personal nostalgia in turn provides emotional utility and familial utility to the donor. This in turn helps increase the commitment of the donor to the charitable organization. Which enhances the donor's intention to donate to that charity.

\section{THEORETICAL CONTRIBUTION}

This research has several theoretical contributions. It contributes to two streams of literature, the charitable giving literature as well as the literature on nostalgia. In the charitable giving literature it responds to the call for more research on constructs that emotionally engage the donor (e.g. Sargeant et al., 2006, Merchant and Ford, 2008). The author has not found any research which has studied the relationship between personal nostalgia and charitable giving. By exploring this linkage in detail the author fills in a crucial gap in the literature. This research also builds on the work of Wildschut (2006), 
Holbrook (1993), Batcho (1998) and Holak and Havlena (1998) in the nostalgia

literature. The author has not found any study that has comprehensively looked at the role of the factors that influence nostalgia. By developing an extensive model incorporating the various factors that influence personal nostalgia, this research fills in that gap. The context of charitable giving is a new and relevant dimension. This more extensive model has incorporated and empirically tested many factors influencing personal nostalgia, some of which (e.g. recovery from grief) had not been studied in the context of nostalgia so far.

\section{MANAGERIAL IMPLICATIONS}

This study has many implications for the NPO Marketing Manager in the areas of communications development, targeting and social networking.

\section{Developing fundraising communications that evoke personal nostalgia}

In the for profit sector in the U.S., marketers have frequently used nostalgic appeals to evoke personal nostalgia in the advertisements and other communications of products and services. Some recent examples are Nesquick (from Nestle) which urges consumers to "Remember and relive the wonderful years of the past" by sipping on a hot cup of Nesquick at a Shell gas station. Sellers of cars evoke personal nostalgia and promise older consumers to "find their youth once again" (Saranow, 2008, page W2). Makers of toys enable 30 year olds to relive their childhood by buying modern versions of "oldie" toys for their kids (Lapp, 2008). This is evident in the comeback of classic toys like cabbage patch dolls and transformers. This is true in other markets as well. Holak et al. (2008) found that, in Russia, there is a surge in the demand for a variety of products like tea, cigarettes, etc which evoke personal nostalgia among the consumers. 
This study shows that in the charitable giving context personal nostalgia helps emotionally engage the donor (Hypotheses 6 and 7). The NPO Marketing Manager could develop fundraising communications that could bring back personal nostalgic memories for the giver and elicit the warmth of fond personal experiences. The results of this study also show that past experiences associated with the NPO influence the personal nostalgia of the donor (Hypothesis 2). Hence, Marketing Managers of these NPOs could benefit by identifying significant personal experiences of the donor associated with the NPO and evoke nostalgia by giving them a window to re-experience those events. This would be particularly helpful for such organizations as universities, hospitals, schools and social causes as well as health-related charities. An example of such an appeal in a fundraising context is presented in Figure 5-1.

Figure 5-1 - Example of nostalgic appeal

Remember high school days... the classroom, the teachers, sports and prom nights ....the fun and the dreams ....those were the days!

Now reconnect with the magic of the past by donating money to your

High School Alumni Association for a new computer laboratory for the students.

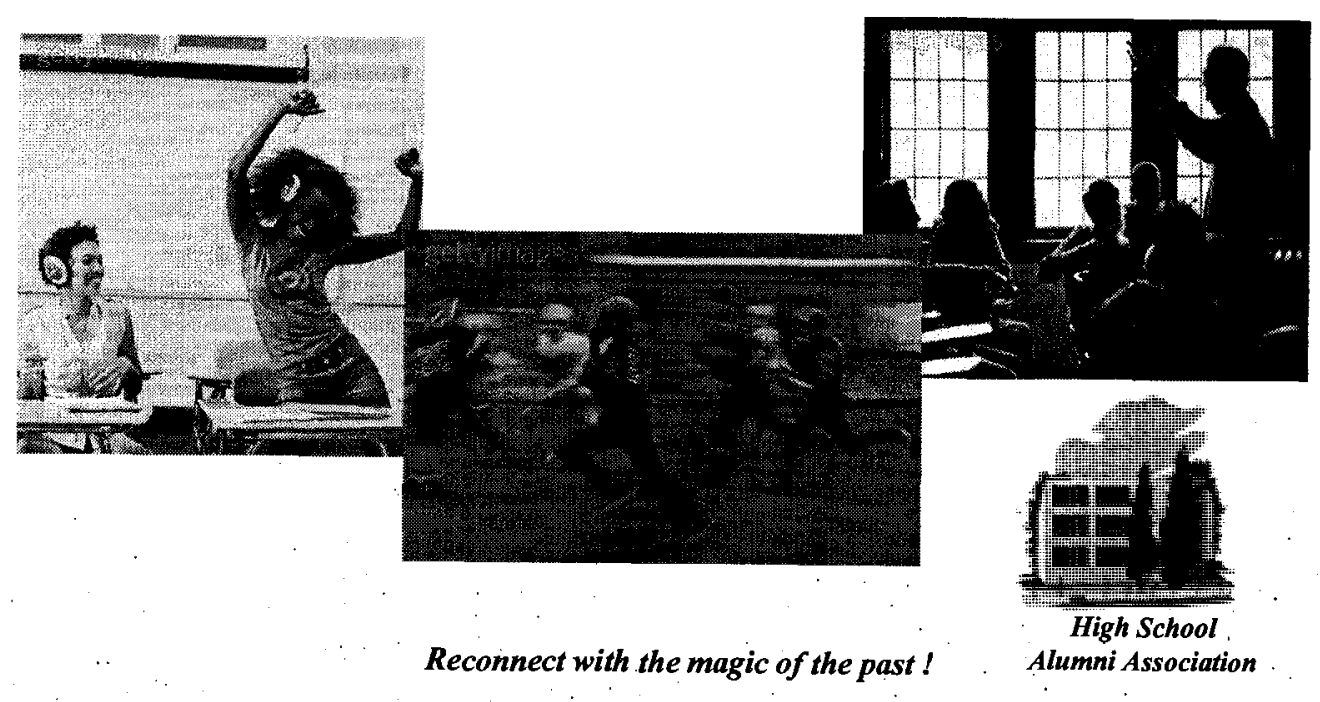




\section{Additional variables for segmenting and targeting the donors}

Would the nostalgic appeal work with all kinds of donors? Personal nostalgia literature (Holbrook, 1993, Batcho, 1995) shows that consumers differ in their propensity to be nostalgic. Would nostalgic appeals have an adverse effect on the low nostalgia prone donors? Would this isolate the forward looking or progressive donors? Holbrook and Schindler (1991) concluded that high nostalgia prone consumers are more open to nostalgia appeals than low nostalgia prone individuals. Schindler and Holbrook (2003) stated that since nostalgic appeals evoking the past may not be successful among the low nostalgia prone individuals, they recommend that more progressive appeals need to be used which could evoke the heritage of the product or brand but also cue modernity.

Thus, for a communication strategy that evokes personal nostalgia to be effective it may be helpful to gauge the nostalgia proneness of the donor. The results of this research show that donor's who are experiencing discontinuity, loneliness and are recovering from grief are more likely to feel nostalgic (Hypotheses 1,3 and 5). Hence it may be relevant for NPOs to track these factors among their donors. Using these variables, nostalgic communications could then be targeted more effectively to the relevant donors. An issue that warrants discussion here is that how can the NPO track these personality and life stage factors of the donor.

Gielens and Steenkamp (2007) provide some directions on this. In a new product adoption context, they asked consumers who were members of a consumer club to fill out questions on an innovativeness scale. On the bases of each of the consumer's score on the scale they were grouped into the high innovative or the low innovative group. Consumer product companies then modified their promotion package according to the different 
level of innovativeness of the consumer, thus new product news and deals were sent to consumers who were more innovative. In the context of charitable giving as part of the marketing research/ feedback initiative, NPOs may request some of the above stated information from the donor by using modified versions of the scales utilized in this study to measure personal nostalgia, discontinuity; loneliness and recovery from grief. This information can then be used to segment the donors and target the relevant donors with more nostalgic appeals.

Using personal nostalgia across the NPOs Integrated Marketing Communications (IMC) program

The findings of this study show that the greater the emotional engagement derived through personal nostalgia the greater the commitment to the NPO that is evoking nostalgia (Hypothese 8 and 9). Thus, in addition to fundraising communications NPOs must evoke personal nostalgia across their IMC program. An example of how this can be used in another element of the IMC program is discussed below.

In today's world of social networking it may also be viable for NPOs to create on line egroups or virtual communities where donors could bond, share their past experiences and exchange stories. This could help create continual emotional engagement around the NPO, as it would keep the web of memories around the NPO alive and vibrant. The NPO evoking personal nostalgia thus becomes a platform for socialization. An example of this is seen in e-groups created by ex students of Craddock high school (VA). Alumni of Craddock high school have created a web page to exchange stories and memories of the past. This 1000 member group's key appeal is "Do you remember...The good old days in 
Craddock" (Hoyer, 2008, page 9). Another example is the group formed by parents of children who died out of Sudden Unexplained Death. Around 700 members of this group meet each year (in Virginia Beach) for an annual fund raiser run in the memory of their deceased child. This nostalgic event aids them to cope with their grief (Jiggetts, 2007). This event also serves as a platform for them to discuss their stories with each other. The money they raise goes to hospitals for medication and research in the area of sudden unexplained deaths.

\section{LIMITATIONS OF THIS STUDY}

This research has the following limitations and weaknesses. Firstly, this research uses the Batcho (1995) scale to measure the proneness to be nostalgic, but it does not measure the intensity of the personal nostalgia the respondent is experiencing. Secondly, this study explains $15.1 \%$ of the variance in personal nostalgia. It is evident there are other factors which also influence personal nostalgia and future studies may focus on capturing them. Thirdly, this model takes the intention to donate as the proxy for giving behavior. Marketers may take caution while extrapolating intention to donate for giving. There may be other factors that may mediate or moderate the relationship between intention to donate and actual giving. Future studies may want to study this linkage in more depth. Fourthly, the model in this study assumes a single direction causal relationship between emotional engagement and commitment. There may be actions of the NPO (like Thank You notes, acknowledgement etc) which could enhance the donors emotional utility and further strengthen the commitment to the NPO. This could also be an avenue for further research. Fifthly, the emotional benefits derived out of giving have 
been grouped together under "emotional utility". It is critical to unravel the construct of EU to study the rich nuances of the emotions experienced in the process of giving to charity. This study only retained the items of positive emotions, future studies could also look at the role of negative emotions. Sixthly, this study did not study the influence of personal nostalgia on the emotional engagement of non donors. Lastly, the current study used cross sectional data, future researches may want to use experimental design to test the impact of nostalgic appeals on charitable giving.

\section{DIRECTIONS FOR FUTURE RESEARCH}

The next couple of pages present some research ideas for future studies around the areas of charitable giving and personal nostalgia.

NPO insights - WHRO

It may be relevant to test this model among the donors of a specific NPO like WHRO. This study would enhance our understanding as well as revalidate the findings of this study. This could also present an opportunity to test the effects of nostalgic appeals (like Figure 5-1) among a real life donor sample.

Scale to measure the intensity of the personal nostalgia experience

A review of the nostalgia literature has shown that there are scales that measure the proneness or propensity for an individual to be nostalgic (Holbrook, 1993, Batcho, 1995). However, these scales do not measure the intensity of the cognitive and emotional elements of the experience of personal nostalgia. As personal nostalgia constitutes an interplay of memories and emotions, in order to effectively measure the intensity of the personal nostalgia experience, future studies could proceed towards developing a scale that measures both the dimensions of personal nostalgia - cognitive and emotional. (Baumgartener, 1992). 
Effect of Time orientation on Charitable Giving: Going Beyond Nostalgia

This study has looked at the effect of nostalgia on charitable giving. However, a review of the psychology literature shows that nostalgia is just one type of time orientation and that there are five types of time orientation: past negative, past positive (nostalgia), present fatalistic, present hedonistic and future (Zimbardo and Boyd, 1999). Time orientation influences how consumers think, act and behave (Bergadaa 1990, Gonzalez and Zimbardo, 1985), and influences values, behavior and emotions. The effect of time orientation has been studied in the context of consumer innovativeness, recreational shopping, risky driving etc. However, the effect of all time orientations on charitable giving has not yet been studied and could be a springboard for future researches.

\section{Emotions in giving}

Roseman et al. (1990) have demonstrated that the most discrete emotions occur in response to appraisals of events happening to persons or experiences they have. Sadness is frequently accompanied by feelings to be comforted. People tend to maintain positive mood states and focus on moving away or changing their negative mood states (Isen et al., 1987). Thus it can be argued that when a person experiences stimulus that makes him feel negative emotions, he would feel motivated to overcome the negative emotions. In the context of charitable giving, appeals that generate negative emotions (e.g. figure 5-2) and urge donors to help are likely to take the donor through different emotional stages emotions preceding giving to charity, the emotions anticipated by giving and the emotions experienced after giving to charity. There is not much academic work around 
this area and future studies could experimentally study the emotional nuances involved in the various stages of giving to charity.

Figure 5-2 - Generating negative emotions

Jane and her brother have never been to school !

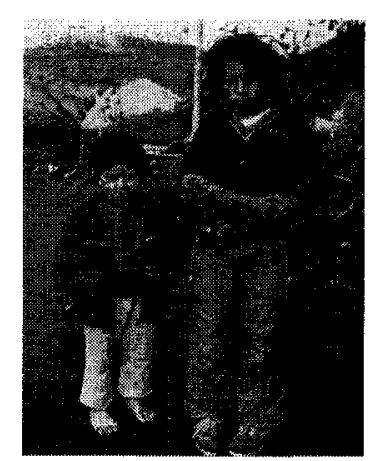

There are 77 million children worldwide unable to attend school and many others will drop out before completing their primary education. Without education these children have little hope of breaking away from the circle of poverty and abuse.

\section{Role of being "Thanked"}

In the branding literature Woodside et al. (2008) state that brands tell stories and consumers want to be involved in these stories and want their roles reconfirmed. In the context of NPOs, it can also be argued that the NPO brand tells the donor a story (e.g. World Christian Fund, Operation Smile etc). The "Thank you" note that the NPO sends to the donor may act as the confirmation of the donor's role in participating in the story. Bennett (2006) argues that there is a positive impact of "being acknowledged" by the NPO on the Donor's Lifetime Value.

To test the role of being thanked 502 donors (the dissertation sample) were asked whether they were thanked by the NPO they had donated to. ANOVA was run to see if the scores for future intentions to donate, commitment, emotional utility and amount donated were significantly different between those who said that they did receive a thanks note versus 
those who said that they did not receive a thank you note. It was expected that the mean scores would be higher for those who had been thanked. However, at an aggregate sample level there were no significant differences.

To probe this deeper the sample was broken into two groups. The first group comprised those donors who had donated more frequently than the sample average (4 times or more) and the second group comprised those who were infrequent donors (3 times or less). ANOVA was run on both these groups separately. There was no difference in the frequent donor group among those who received a thanks note versus those who did not. It appears that a thanks note did not drive engagement to this group. The ANOVA among the infrequent donor group had some interesting findings (see Table 5$1)$.

\begin{tabular}{|c|c|c|c|c|c|c|}
\hline \multicolumn{7}{|c|}{ Table 5-1 - ANOVA among infrequent donors } \\
\hline & & Sum of Squares & df & Mean Square & $\mathbf{F}$ & Significance \\
\hline \multirow{3}{*}{ EMOTIONAL UTILITY } & $\begin{array}{r}\text { Between } \\
\text { Groups }\end{array}$ & 4.357 & 1 & 4.357 & 4.870 & $0.029^{*}$ \\
\hline & $\begin{array}{l}\text { Within } \\
\text { Groups }\end{array}$ & 98.420 & 110 & 0.895 & & \\
\hline & Total & 102.777 & 111 & & & \\
\hline \multirow{3}{*}{ COMMITMENT } & $\begin{array}{r}\text { Between } \\
\text { Groups }\end{array}$ & 2.815 & 1 & 2.815 & 2.950 & $0.089 * *$ \\
\hline & $\begin{array}{l}\text { Within } \\
\text { Groups }\end{array}$ & 104.932 & 110 & 0.954 & & \\
\hline & Total & 107.746 & 111 & & & \\
\hline \multirow{3}{*}{ INTENTION TO DONATE } & $\begin{array}{r}\text { Between } \\
\text { Groups }\end{array}$ & 3.278 & 1 & 3.278 & 3.910 & $0.051^{\star \star}$ \\
\hline & $\begin{array}{l}\text { Within } \\
\text { Groups }\end{array}$ & 92.213 & 110 & 0.838 & & \\
\hline & Total & 95.491 & 111 & & & \\
\hline \multirow{3}{*}{ AMOUNT DONATED } & $\begin{array}{r}\text { Between } \\
\text { Groups }\end{array}$ & 103612.329 & 1 & 103612.329 & 5.825 & $0.017^{*}$ \\
\hline & $\begin{array}{l}\text { Within } \\
\text { Groups }\end{array}$ & 1956760.091 & 110 & 17788.728 & & \\
\hline & Total & 2060372.420 & 111 & & & \\
\hline
\end{tabular}


This showed that there was significant difference among those who said that they were thanked versus those who were not. The mean scores of emotional utility, intention to donate, amount donated and commitment was significantly higher among those who were thanked when compared to those who were not. Thus; it appears that among infrequent donors "Thanking" does help increase engagement. This of course is only preliminary and more work could be done by future researches to enhance our understanding of how NPO brands tell stories and how being thanked reconfirms the donors role in the story and strengthens his emotional attachment to the NPO.

\section{Donation habits}

As a part of many religious rituals and even routine behavior, donating to charity sometimes becomes a habit. Does this habit endure forever? Would a proactive reassurance from the NPO enhance the commitment the donor has to the NPO? On the other hand would apathy from the NPO lead to a breaking of this habit. The area of habitual donation has not been studied in depth and would be an interesting area for future researches.

\section{CLOSING REMARKS}

This research has studied how various factors (like discontinuity, loneliness, aging, recovery from grief and past experiences) influence personal nostalgia. It also studied the effect of personal nostalgia on commitment to the NPO and how this commitment influences the intention to donate. Ten research hypotheses were presented. Data were collected from 502 U.S. donors. Structural equation model was run and the statistical tests found support for nine of the research hypotheses. The managerial 
implications of this study along with its limitations were discussed. Lastly, directions for future researches were presented. 


\section{REFERENCES}

Association Of Fundraising Professionals (2007), Target Analysis Group Report, http://www.targetanalysis.com/NatIndexQ207.php

Aiken, Damon K. (1999), "Manufactured Memories and Nostalgia Advertising," American Marketing Association Conference Proceedings, 44-51.

Akhtar, S. (1996), "“Someday..." and "If only..." Fantasies; pathological optimism and inordinate nostalgia as related forms of idealization," Journal of the American Psychoanalytic Association, 44 (3), 723-753.

American heritage dictionary (1972). New York: Dell

Anderson, James and David Gerbing (1988), "Structural Equation Modeling in Practice: A Review and Recommended Two-Step Approach," Psychological Bulletin, 103(3), 411-423

Andreoni, James (1990), "Impure Altruism and Donations to Public Goods: A Theory of Warm-Glow Giving," The Economic Journal, 100, 464-477

Baker, Stacey Menzel and Patricia F. Kennedy (1994), "Death By Nostalgia: A Diagnosis of Context-Specific Cases," Advances in Consumer Research, 21, 169-174

Bassin, D. (1993), "Nostalgic objects of our affection: mourning, memory and maternal subjectivity," Psychoanalytic Psychology, 10, 425-436

Batcho, Krystine Irene (1995), "Nostalgia a psychological perspective," Perceptual and Motor Skills, 80, 141-143

Batcho, Krystine Irene (1998), "Personal nostalgia, world view, memory and emotionality," Perceptual and Motor Skills , 87, 411-432

Baudrillard, Jean (1983), Simulations, New York : Columbia University

Baumgartner, Hans (1992), "Remembrance of things past : Music, autobiographical memory and emotion," Advances in Consumer Research,19, 613-620

Belk, Russell (1979), "Gift giving behavior". In J.N. Sheth (Ed). Research in Marketing, 2, 95-126. Greenwich CT: JAI Press.

Belk, Russell (1990), "The Role of Possessions In Constructing and Maintaining A Sense of Past," Advances in Consumer Research, 17, 669-674

Belk, Russell (1991), "Possessions and the sense of past" in Highways and buyways, Association for Consumer Research

Belk, Russell and Janeen Arnold Costa (1998), "The Mountain man myth : A contemporary consuming fantasy," Journal of Consumer Research, 25(3), 218-240

Belk, Russell, Melanie Wallendorf, and John F. Jr Sherry (1989), "The sacred and the profane in consumer behavior ; Theodicy on the Odyssey," Journal of Consumer Research, 16(1), 1-38

Bernsten, D. and D.C. Ruben (2002), "Emotionally charged autobiographical memories across the life span: The recall of happy, sad, traumatic, and involuntary memories," Psychology and Aging, 17, 636-652 
Bennet, Roger (2006), "Predicting the lifetime durations of donors to charities," Journal of Nonprofit and Public Sector Marketing, 15 (1/2), 45-66

Bentler, P.M. (1992), "On the fit of models to covariances and methodology to the Bulletin," Psychological Bulletin, 112, 400-404

Bergadaa, Michelle M. (1990), "The role of time in the action of the consumer," Journal of Consumer Research, 17 (December), 289-302

Best, Joel and Edward E. Nelson (1985), "Nostalgia and discontinuity: A test of the Davis hypothesis," Sociology and Social Research, 69, 221-2223

Betts, George H. (1909), The distribution and functions of mental imagery, New York : Columbia University,

Bewes, Timothy (1997), Cynicism and Postmodernity, London:Verso

Bluck, S. and T. Habermas (2000), "The life story scheme," Motivation and Emotion, $24,121-145$

Bonanno, G.A. and S. Kaltman (1999), "Toward an integrative perspective on bereavement," Psychological Bulletin, 125, 760-776

Bonnano, G., C. Wortman and R. Nesse (2004), "Prospective patterns of resilience and maladjustment during widowhood," Psychology and Aging, 19, 260-271

Bollen, K.A. (1989), "A new incremental fit index for general structural models," Sociological Methods and Research, 17, 303-316

Bosnjak, Michael, Mirta Galesic and Tracy Tuten (2006), "Personality determinants of online shopping: Explaining online purchase intentions using a hierarchical approach," Journal of Business Research, 60 (6), 597-605

Bradburn, N. (1969), The structure of psychological well being, Chicago:Aldine

Braun-LaTour, Kathryn, Michael S. Latour, Jacqueline E. Pickrell and Elizabeth Loftus (2004), "How and when advertising can influence memory for consumer experience," Journal of Advertising,33 (4), 7-25

Braun-LaTour, Kathryn and Michael S. Latour (2005), "Transforming Consumer Experience," Journal of Advertising, 34 (3), 19-30

Braunsberger, Karin, Hans Wybenga and Roger Gates (2007), "A comparison of reliability between telephone and web-based surveys," Journal of Business Research, 60 (7), 758-764

Braus, P. (1994), "Will baby boomers give generously," American Demographics, 16 (7), 48-52

Bricklin, Barry (2001), "Nostalgia, Integration, Validity Issues, and generative power: Some thoughts on Zygmunt A. Piotrowski," Journal of Personality Assessment,76 (2), 194-199

Brown, David W. (2004), "What research tells us about planned giving," International Journal of Nonprofit and Voluntary Sector Marketing, 9, 86-95

Brown, G. (1974), "Meaning, measurement and stress of life events," In B.S. Dohrenwend and B.P. Dohrewend (Eds), Stressful Life Events: Their nature and effects, New York: Wiley 
Burke, C. (2001), "Nonprofit history's new numbers (and the need for more)," Nonprofit and Voluntary Sector Quarterly, 30 (2), 174-203

Cacioppo, J., and G. Bernston (1994), "Relationship between attitudes and evaluative space: A critical review, with emphasis on the separability of positive and negative substrates," Psychological Bulletin, 115, 401-423

Carnelly, K., C. Wortman, N. Bolger and C. Burke (2006), "The time course of grief reactions to spousal loss: Evidence from a national probability sample," Journal of Personality and Social Psychology, 91 (3), 476-492

Chase, M. and Christopher Shaw (1989), "The dimensions of nostalgia" in Shaw and Chase (eds) The Imagined Past: History and Nostalgia, Manchester University Press

Churchill, G. (1979), "A paradigm for developing better measures of marketing constructs," Journal of Marketing Research, 16, 64-73

Cialdini, R., Mark Schaller, Donald Houlihan, Kevin Arps, Jim Fultz and Arthur L. Beaman (1987), "Empathy-Based Helping: Is it Selflessly or Selfishly Motivated?," Journal of Personality and Social Psychology, 52(4), 749-758

Clarke, D.C. (1995), "Life scripts: Implicit representations of life course patterns," Journal of Social Behavior and Personality, 10, 871-884

Cohen, Jacob (1992), “A Power Primer,” Psychological Bulletin, 112(1), 155-159

Conway, M.A. (2001), "Sensory perceptual episodic memory and its context: autobiographical memory," Philos. Trans. R. Soc. Lond., 356, 1375-1384

Conway, M.A. and C.W. Pleydell-Pearce (2000), "The construction of autobiographical memory in self memory system," Psychological Review, 107, 261-288

Coyle, James and Esther Thorson (2001), "The effects of progressive levels of interactivity and vividness in Web marketing sites," Journal of Advertising, 30, 65-77

Croft, A. (1989), "Forward to the 1930s; A literary politics of amnesia" in Shaw and Chase (eds) The Imagined Past: History and Nostalgia, Manchester University Press

Daniels, E.B. (1985), "Nostalgia and hidden meaning," American Imago, 42 (4), 371 383

Davis, Fred (1979), Yearning for Yesterday. New York : The Free Press

Diener, E. and A. Iran-Nejad (1986), "The relationship experience between various types of affect," Journal of Personality and Social Psychology, 50, 1031-1038

Edmondson, B. (1986), "Who gives to charity?,"American Demographics,8, 44-49

Eikenberry, Angel M (2005), "Fundraising or promoting philanthropy? A qualitative study of the Massachusetts Catalogue for Philanthropy," International Journal of Nonprofit and Voluntary Sector Marketing, 10, 137-149

Ellen, Pam S. and Pula F. Bone (1991), "Measuring communication evoked imagery processing," Advances in Consumer Research, 18

Elson, Miriam (1992), "Restoring Continuity: The View From Within," Psychoanalytic Psychology, 9(3), 369-385

Fielding, Michael (2007), "The Consumer Panel Reinvented," Marketing Research; 19 (3), 35-38 
Feldman, D and B. Feldman (1985), "The effect of telethon on attitudes towards disabled people and financial contributions," Journal of Rehabilitation, 51, 42-45

Firat, Faut A and Alladi Venkatesh (1995), "Liberatory postmodernism and enchantment of consumption," Journal of Consumer Research, 22 (3),239-267

Fischer, Eileen, Brenda Gainer and Stephen J. Arnold (1996), "Gift giving and charitable donating: How (Dis)similar are they ?," in Gift Giving ; A research anthology, $\mathrm{OH}$ : Bowling Green State University

Fornell, C and D.F. Larker (1981), "Evaluating structural equation models with unobservable and measurement errors," Journal Of Marketing Research, 18, 39-51

Frued, Sigmund (1926), Inhibitions, symptoms and anxiety, S.E. 20, 75-172

Fultz, J. C., D. Batson, V.A. Fortenbach, P. McCarthy and L.L. Varney (1986), "Social evaluation and the empathy altruism hypothesis," Journal of Personality and Social Psychology,50,761-769

Gardener, Meryl Paula (1985), "Mood states and consumer behavior: A critical review," Journal of Consumer Research, 12(3), 281-300

Gielens, Katrijn and Jan-Benedict Steenkamp (2007), "Drivers of consumer acceptance of new packaged goods: An investigation across products and countries," International Journal of Research in Marketing, 24, 97-111

Giving USA (2007), Giving USA Foundation

Goalder, James S (1985), "Morbid Grief Reaction: A social systems perspective," Professional Psychology: Research and Practice, 16( 6), 833-842

Goulding, Christina (2001), "Romancing the past: Heritage visiting and the nostalgic consumer," Psychology and Marketing, 18, 565-580

Goulding, Christina (2002), "An exploratory study of age related vicarious nostalgia and aesthetic consumption," Advances in Consumer Research, 29, 542-546

Gonzalez, A and Philip Zimbardo (1985), "Time in Perspective : The sense we learn early affects how we do our jobs and enjoy our pleasures," Psychology Today, 19 (March), 21-26

Hair, Joseph, William Black, Barry Babin, Rolph Anderson and Ronald Tatham (2006), Multivariate Data Analysis, Prentice Hall: New Jersey

Halfpenny, P. (1990), "Charity household survey 1988/9", Tonbridge: Charities Aid Foundation.

Hawthorne, G. (2006), "Measuring social isolation in older adults: development and initial validation of the friendship scale," Social Indicators Research, 77, 521-548

Hofer, Johannes (trans. Carolyn Kiser Anspach)(1934), "Medical Dissertation on Nostalgia by Johannes Hofer, 1688," Bulletin of History of Medicine , 2, 376-391.

Holak, Susan L. and William J. Havlena (1992), "Nostalgia: An exploratory study of themes emotions in the nostalgic experience," Advances in Consumer Research, 19, 380-387

Holak, Susan L. and William J. Havlena (1998), "Feelings, Fantasies, and Memories: An Examination of the Emotional Components of Nostalgia," Journal of Business Research, 42, 217-226 
Holak, Susan L. , Alexei Matveev and William Havlena (2008), "Nostalgia in postsocialist Russia: Exploring applications to advertising strategy," Journal of Business Research, 61, 172-178

Holbrook, Morris B and Robert Schindler (1991), "Echoes of the dear departed ; Some work in progress on Nostalgia," Advances in Consumer Research, 18, 330-333

Holbrook, Morris B (1993), "Nostalgia and Consumption Preferences: Some Emerging Patterns of Consumer Tastes," Journal of Consumer Research, 20, 245-256

Holbrook, Morris B and Robert Schindler (2003), "Nostalgic bonding: Exploring the role of nostalgia in the consumption experience," Journal of Consumer Behavior, 3, 107-127

Holmes, T., and R. Rahe (1967), "The social readjustment rating scale," Journal of Psychomatic Research, 11, 213-218

Hoyer, Meghan (2008), "The good old days in Cradock," The Virginian Pilot, February, 3

Hu, L.T. and P.M. Bentler (1999), "Cutoff criteria fir fit indexes in covariance structure analysis: Conventional criteria versus new alternatives," Structural Equation Modeling: A Multidisciplinary Journal, 6, 1-55

Isen, Alice M, Kimberly A Daubman and Gary P. Nowicki (1987), "Positive Affect Facilitates Creative Problem Solving," Journal of Personality and Social Psychology, $52(6), 1122$

Jiggetts, Jennifer (2007), "Jacob's run for a reason is one to remember," The Virginian Pilot, October, 15

Jones, W., J.R. Freemon and R.A. Goswick (in press), "The persistence of loneliness: self and other rejection?," Journal of Personality

Joy, Annamma and John Sherry (2003), "Speaking of art as embodied imagination: A multisensory approach to understanding aesthetic experience," Journal of Consumer Research, 30 (2), 259-281

Kanungo, Rabindra N. (1979), "The Concepts of Alienation and Involvement Revisited," Psychological Bulletin, 86(1), 119-138

Kaplan, H.A. (1987), "The psychopathology of Nostalgia," The Psychoanalytic Review, 74 (4), 465-486

Kottasz, Rita (2004), "How should charitable organizations motivate young professionals to give philanthropically," International Journal of Nonprofit and Voluntary Sector Marketing, 9, 9-27

Lanyon, R. (1970), "Development and validation of a psychological screening inventory," Journal of Consulting and Clinical Psychology, 35, 1-24

Lapp, Alison (2008), "Classic toys make a comeback," The Virginian Pilot, January, 1

Larsen, Jeff, Peter McGraw and John Cacioppo (2001), "Can people feel happy and sad at the same time," Journal of Personality and Social Psychology, 81, 4, 684-696

Lears, J. (1998), "Looking backward : In defense of nostalgia," Lingua Franca: The Review of Academic Life, 7, 59-66 
Leon, W and M. Piatt (1989), "Living history museums," In W.Leon and R.Rosenweig (Eds), History museums in the United States: A critical assessment, Urbana: University of Illinois

Lipman, Harvey (2007), "Most giving doesn't aid poor," The Record -Non-Profit News, (North Jersey Media Group Inc), http://global.factiva.com/ha/default.aspx

Lomsky-Feder, Edna and Tamar Rapoport (2000), "Visit, separation and deconstructing nostalgia," Journal of Contemporary Ethnography, 29 (1), 32-57

MacInnis, Deborah J. and Linda L. Price (1987), "The role of imagery in information processing: Review and extensions," Journal of Consumer Research, 13 (March), 473491

Maffesoli, Michael (1996), The Time Of The Tribes: The Decline Of Individualism In Mass Society, London : Sage

Mansell, W. and D. Lam (2004), “A preliminary study of autobiographical memory in remitted bipolar and unipolar depression and the role of imagery in the specificity of memory," Memory, 12(4), 437-446

Mathur, Anil (1996), "Older Adults Motivations for Gift Giving to Charitable Organizations: An Exchange Theory Perspective," Psychology and Marketing, 13, 107123

McCann, Willis H. (1941), "Nostalgia: A review of the literature," Psychological Bulletin, 38, 165-182

McDermott, Sinead (2002), "Memory, Nostalgia and Gender in " A thousand Acres"," Signs, 28, 1, 389-407

Mehta, Raj and Russell Belk (1991), "Artifacts, Identity and transition: favorite possessions of Indians and Indian immigrants to the United States," Journal of Consumer Research,17,398-411

Merchant, Altaf and John Ford (2008), "Nostalgia and giving to charity: A conceptual framework for discussion and research," International Journal of Nonprofit and Voluntary Sector Marketing, 13, 13-30

Morgan, Robert M. and Shelby D. Hunt (1994), "The Commitment-Trust Theory of Relationship Marketing," Journal of Marketing, 3, 20-38

Morris, P.E. and P.J. Hampson (1983), Imagery and Consciousness. London: Academic Press

Mottner, Sandra and John Ford (2003), "Measuring nonprofit marketing strategy performance: the case of museum stores," Journal of Business Research, 58(6), 829840

Nawas, M.M. and J.J. Platt (1965), "A future oriented theory of nostalgia," Journal of Individual Psychology, 21 (1), 51-57.

Noble, Charles and Beth Walker (1997), "Exploring the relationships among liminal transitions, symbolic consumption, and the extended self," Psychology and Marketing, $14(1), 29-47$

Olson, Mancur (1965), The Logic Of Collective Action, Harvard University Press. 
Ornstein, A. and P. Ornstein (1985), "Clinical understanding and explaining: The empathic vantage point," In A. Goldberg (Ed), Progress in Self Psychology, 1, 43-61, New York: Guilford

Perlman, D., A.C. Gerson and B. Spinner (1978), "Loneliness among senior citizens: An empirical report," Essence, 2(4), 239-248

Peters, Roderick (1985), "Reflections on the origin and aim of nostalgia," Journal of Analytical Psychology, 30, 135-148

Pharoah, C. and S. Tanner (1997), "Trends in charitable giving," Fiscal Studies, 18 (4), 427-443

Price, Linda L, Eric Arnould and Carolyn Folkman Curasi (2000), "Older Consumer's disposition of special possessions," Journal of Consumer Research, 27(2) , 179-201

Probyn (1996), "Memory, Nostalgia and Gender in "A Thousand Acres"' by Sinead McDermott (2002), Signs: Gender and Cultural Memory, 28 (1), 389-407

Punj, Girish (2006), "Structural Modeling in Marketing: Some Future Possibilities," Marketing Science, 25 (6), 622-626

Radley, A and M. Kennedy (1995), "Charitable giving by individuals: A study of attitudes and practices," Human Relations, 48 (6), 685-709

Ranganathan, S.K. and Walter Henley (2007), "Determinants of charitable donation intentions: A structural equation model," International Journal of Nonprofit and Voluntary Sector Marketing (in press)

Rose, Randall and Stacy L. Wood (2005), "Paradox and the consumption of authenticity through reality television," Journal of Consumer Research, 32 (2) , 284296

Roseman, Ira J, Martin Spindel and Paul Jose (1990), "Appraisals of Emotion-Eliciting Events: Testing a Theory of Discrete Emotions," Journal of Personality and Social Psychology, 59 (5), 899

Rubin, D.C., T.A. Rahlal and L.W. Poon (1998), "Things learnt in early adulthood are remembered best," Memory and Cognition, 26, 3-19

Russell, D., L. Peplau and C. Cutrona (1980), "The revised UCLA loneliness scale: concurrent and discriminant validity evidence," Journal of Personality and Social Psychology, 39(3), 472-480

Russell, James, A. and James M. Carroll (1999), "On the bipolarity of positive and negative affect," Psychological Bulletin, 125 (1), 3-30

Saranow, Jennifer (2008), "The car that got away," Wall Street Journal, January, 11

Sarason, I., C. De Monchaux and T. Hunt (1975), "Methodological issues in assessment of life stress," In L. Levi (Ed), Emotions- Their Parameters and Measurement, New York: Raven Press

Sarason, I., J. Johnson and J. Siegel (1978), "Assessing the impact of life changes: Development of Life Experiences Survey," Journal of Consulting and Clinical Psychology, 46(5), 932-946

Sargeant, Adrian, John Ford and Douglas C. West (2000), "Widening the appeal of charity," International Journal of Nonprofit and Voluntary Sector Marketing, 5, 318- 
Sargeant, Adrian and Elaine Jay (2004), "Reasons for lapse: The case of face-to-face donors," International Journal of Nonprofit and Voluntary Sector Marketing, 9, 171182

Sargeant, Adrian and Stephen Lee (2004), "Donor Trust and Relationship Commitment in the UK Charity Sector: The Impact on Behavior," Nonprofit and Voluntary Sector Quarterly, 33, 185-202

Sargeant, Adrian, John Ford and Douglas West (2006), "Perceptual determinants of nonprofit giving behavior," Journal of Business Research, 59, 155-165

Scharlach, Andrew E. (1991), "Factors associated with filial grief following the death of an elderly parent," American Journal of Orthopsychiatry, 6(2), 307-313

Schindler, Robert M. and Morris B. Holbrook (1993), "Critical Periods in the Development of Men's and Women's Tastes in Personal Appearance," Psychology and Marketing, 10, 549-564

Schindler, Robert M. and Morris B. Holbrook (2003), "Nostalgia for Early Experience as a Determinant of Consumer Preferences," Psychology and Marketing, 20, 275-302

Schulkind, M., L. Hennis and D. Rubin (1999), "Music , emotion and autobiographical memory: They're playing your song," Memory and Cognition, 27(6), 948-955

Sehulster, Jerome (1989), "Content and temporal structure of autobiographical knowledge: Remembering the twenty five seasons at the metropolitan opera," Memory and Cognition, 17(5), 590-606

Seremetakis, Nadia C. (1984), The Senses Still, Westview Press

Silver, M (1980), Affluence, Altruism and Atrophy, New York: NY University Press

Sohn, Leslie (1983), "Nostalgia," International Journal Psycho-Anal, 64, 203-211

Stern, Barbara B. (1992), "Historical and Personal Nostalgia in Advertising Text: The Fin De Siecle Effect," Journal of Advertising, 21, 11-22

Stern, Barbara B.(1995), "Consumer Myths: Frye's taxonomy and the structural analysis of consumption text," Journal of Consumer Research, 22(2), 165-185

Tannock, S. (1995), "Nostalgia Critique," Cultural Studies,9, 453-464

Taylor, Martin S. and Victor Konrad (1980), "Scaling dispositions towards the past," Environment and Behavior,12, 283-307

Tesser, Abraham and Beach, Steven R. H. (1998), "Life Events, Relationship Quality, Depression: An Investigation of Judgment Discontinuity in Vivo," Journal of Personality and Social Psychology, 74(1), 36-52

Trilling, Lionel (1972), Sincerity and Authenticity, Cambridge: Harvard University Press.

Unger, Lynette S., Diane M. McConocha and John A. Faier (1991), "The Use of Nostalgia in Television Advertising: A Content Analysis," Journalism Quarterly, 68, 345-353

Waterman, Alan S. (1981), "Individualism and Interdependence," American Psychologist, 36(7), 762-773 
Webber, Daniel (2004), "Understanding charity fundraising events," International Journal of Nonprofit and Voluntary Sector Marketing, 9, 122-134.

Weiss, R.S. (2001), "Grief, bonds and relationships," In M.S. Stroebe, R.O. Hansson, W.Strobe and H. Schut (Eds), Handbook of Bereavement Research: Concequences, Coping and Care, Washington DC: American Psychological Association

Werman, D. (1977), "Normal and pathological nostalgia," Journal of American Psychoanalysis Association, 25, 387-398

Wildschut, T., C. Sedikides, J. Arndt and C. Routledge (2006), "Nostalgia: Content, Triggers, Functions," Journal of Personality and Social Psychology, 91(5), 975-993

Williams, J., H.G. Healy and N.C. Ellis (1999), "The effect of imageability and predictability of cues in autobiographical memory," Quarterly Journal of Experimental Psychology, 52A, 555-579

Woodside, Arch, Suresh Sood and Kenneth Miller (2008), "When consumers and brands talk: Storytelling theory and research in Psychology and Marketing," Psychology and Marketing, 25(2), 97-145

Worden, J.W. (2002), Grief Counseling And Grief Therapy, New York: Springer Publishing Company

Zimbardo, Phillip and John N. Boyd (1999), "Putting time in perspective: A valid, reliable individual-differences metric," Journal of Personality and Social Psychology, 77(6), 1271-1288

Zimmer, Mary R, Sheniqua K. Little and Janice S. Griffiths (1999), "The impact of nostalgia proneness and need for uniqueness on consumer perceptions of historical branding strategies," American Marketing Association Conference Proceedings, 259267 


\section{APPENDIX A}

\section{QUESTIONNAIRE}

1) When was the last time you donated money to any charitable organization in the last 12 months:

1. Within the last week

2. Within the last month

3. Last three months

4. Last six months

5. Six months to twelve months

2) What kind of charitable organization did you last donate money to :

1. Church/ Religious organization

2. Hospital/Medical organization - American Cancer Society etc

3. Academic institution

4. Humanitarian organization - Red Cross, United Way etc

5. Arts organization - Museum, Opera etc

6. Others, please specify

3) How much did you last donate to that charitable organization ?

4) How many times have you EVER donated to that charitable organization?

1. Just once

2. Twice

3. Thrice

4. Four times

5. More than four times

5) What type of charitable organization do you regularly donate money to?

1. Church/ Religious organization

2. Hospital/Medical organization - American Cancer Society etc

3. Academic institution

4. Humanitarian organization - Red Cross, United Way etc

5. Arts organization - Museum, Opera etc

6. Others, please specify

6) Indicate your level of agreement/disagreement with the following statements with regard to the charitable organization you last donated money to:

1. I am likely to donate to the charity in question in the future

2. I will donate the next time

3. I will definitely donate to the charity in question in the future

4. I will recommend the charity to others for donation

5. I feel a sense of belonging to this charitable organization

6. I care about the long term success of

$$
\begin{gathered}
\text { Completely } \\
\text { disagree }
\end{gathered}
$$

12

1

$1-2$

$1 \ldots 2$

1

1

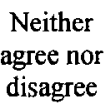

Completely agree

5

5

5

5

5

5 
this charitable organization

7. I would describe myself as a loyal supporter of this charitable organization 8. I will be giving more to this charitable organization next year

9. I often give to this charitable organization because I would feel guilty if I didn't

10. If I never gave to this charitable organization I would feel bad about myself

11. I felt good when I gave money to this charitable organization 12. I felt happy when I gave money to this charitable organization 13. I give money to this charitable organization in memory of a loved one 14. I felt that someone I know might benefit from my support 15. My family had a strong link to this charitable organization

$\begin{array}{lllll}1 & 2 & 3 & 4 & 5 \\ 1 & 2 & 3 & 4 & 5 \\ 1 & 2 & 3 & 4 & 5 \\ 1 & 2 & 3 & 4 & 5 \\ 1 & 2 & 3 & 4 & 5 \\ 1 & 2 & 3 & 4 & 5 \\ 1 & 2 & 3 & 4 & 5 \\ 1 & 2 & 3 & 4 & 5 \\ 1 & 2 & 3 & 4 & 5\end{array}$

7 A) Does the charitable organization you last donated money to remind you of any personal experience in the past?

Yes -1

No - 2 (if no then go to question 8 )

7 B) If YES, please list your life experiences related to the charitable organization in question:

a)

b)

c)

d)

7 C) How vivid are the recollections of the

Not at

all

Extremely personal experience that you are reminded of when you think of this charitable organization? 7 D) How emotional were the recollections of the personal experience that you are reminded of when you think of this charitable organization?

The next set of questions focus on your general perceptions. 8)How much do you miss each of the following from your past.

1.Family

2.Heroes/Heroines Not at all

3.Not having to worry

1

4.Places

5.Music

6.Someone you loved 
8. Things you did

9.Toys

10.The way people were

11.Feelings you had

12.TV shows/movies

13.School

14.Having someone to depend on

15.Holidays

16.The way society was

17.Pets

18. Not knowing sad or evil things

19.Church/religion

20 .Your house

21. Others (please specify)

a)

b)

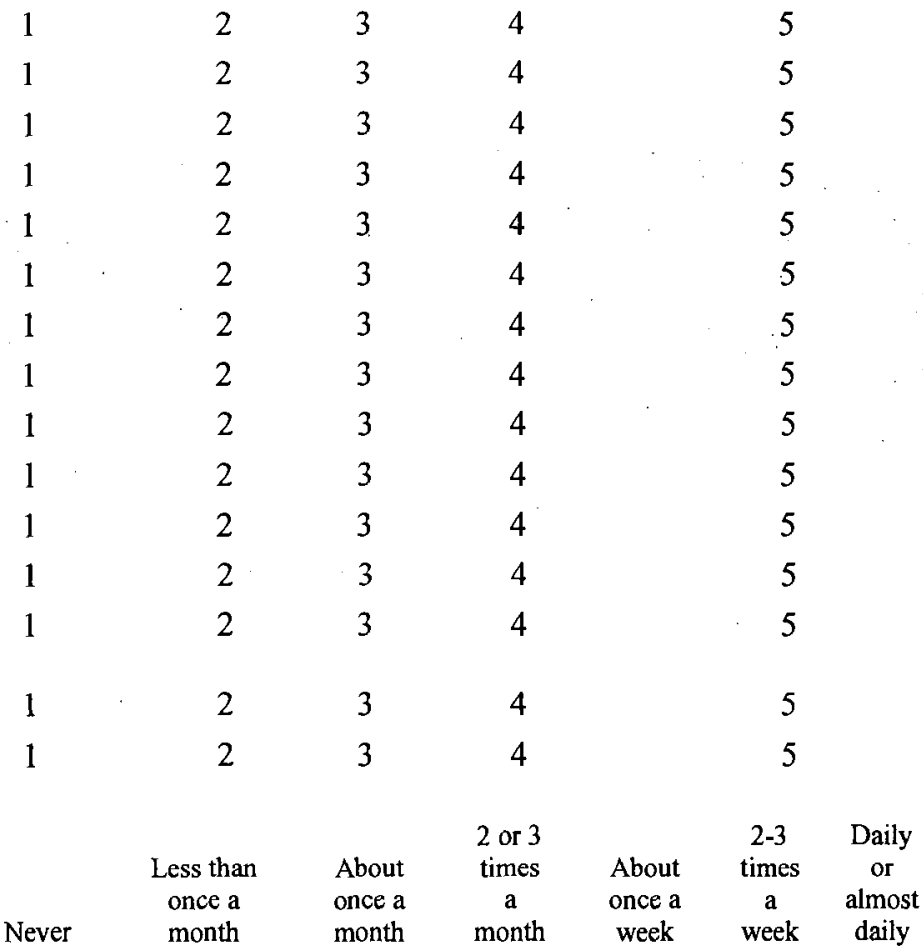

9 A) How often during the last 12

Never

month

month

week

week

daily

months did you have thoughts or memories about a very close relative / friend that is deceased? 9 B) How often during the last 12 months did you talk about a very close relative / friend that is deceased?

9 C) How often did thinking about your late close relative/friend make you feel happy?

9 D) How often did thinking about your late close relative/friend make you feel sad?

9 E) When you think about your

1

2

3

4

5

\section{6}

7

$\begin{array}{ccccccc}1 & 2 & 3 & 4 & 5 & 6 & 7 \\ \text { Never } & \text { Rarely } & \text { Sometimes } & \text { Often } & \begin{array}{c}\text { Almost } \\ \text { always }\end{array} & & \end{array}$

$\begin{array}{ccccc}1 & 2 & 3 & 4 & 5 \\ 1 & 2 & 3 & \begin{array}{c}4 \\ \text { Quite } \\ \text { a bit }\end{array} & 5 \\ \text { Not at all } & \text { A little } & \text { Moderately } & & \text { Extremely }\end{array}$
late friend or relative how happy do you feel?

$9 \mathrm{~F}$ ) When you think about your late friend or relative how sad do you feel? 
10) Indicate how often you feel as described in each of the following statements.

1. I feel in tune with people around me

2. I lack companionship

3. There is no one $I$ can turn to

4. I do not feel alone

5. I feel part of a group of friends

6. I have a lot in common with the people around me

7. I am no longer close to anyone

8. My interests and ideas are not shared by those around me

9. I am an outgoing person

10. There are people I feel close to

11. I feel left out

12. My social relationships are superficial

13. No one really knows me well

14. I feel isolated from others

15. I can find companionship when I want it

16. There are people who really understand me

17. I am unhappy being so withdrawn

18. People are around me but not with me

19. There are people I can talk to

20 . There are people I can turn to

$\begin{array}{cccc}\text { Never } & \text { Rarely } & \text { Sometimes } & \text { Often } \\ 1 & 2 & 3 & 4 \\ 1 & 2 & 3 & 4 \\ 1 & 2 & 3 & 4 \\ 1 & 2 & 3 & 4 \\ 1 & 2 & 3 & 4 \\ 1 & 2 & 3 & 4 \\ 1 & 2 & 3 & 4 \\ 1 & 2 & 3 & 4 \\ 1 & 2 & 3 & 4 \\ 1 & 2 & 3 & 4 \\ 1 & 2 & 3 & 4 \\ 1 & 2 & 3 & 4 \\ 1 & 2 & 3 & 4 \\ 1 & 2 & 3 & 4 \\ 1 & 2 & 3 & 4 \\ 1 & 2 & 3 & 4 \\ 1 & 2 & 3 & 4 \\ 1 & 2 & 3 & 4 \\ 1 & 2 & 3 & 4 \\ 1 & 2 & 3 & 4\end{array}$

11 ) Listed below are a number of events which sometimes bring about a change in the lives of those who experience them. Please check those events which you have experienced in the last 12 months. Also, for each item checked below please indicate the extent to which you viewed the event as having either a positive or a negative impact on your life at the time the event occurred. A rating of -3 would indicate an extremely negative impact. A rating of 0 suggests no impact either positive or negative. A rating of +3 would indicate an extremely positive impact

1 Marriage

2 Detention in jail or comparable institution

3 Death of a spouse

4. Major change in sleeping habits (much more or much less sleep)

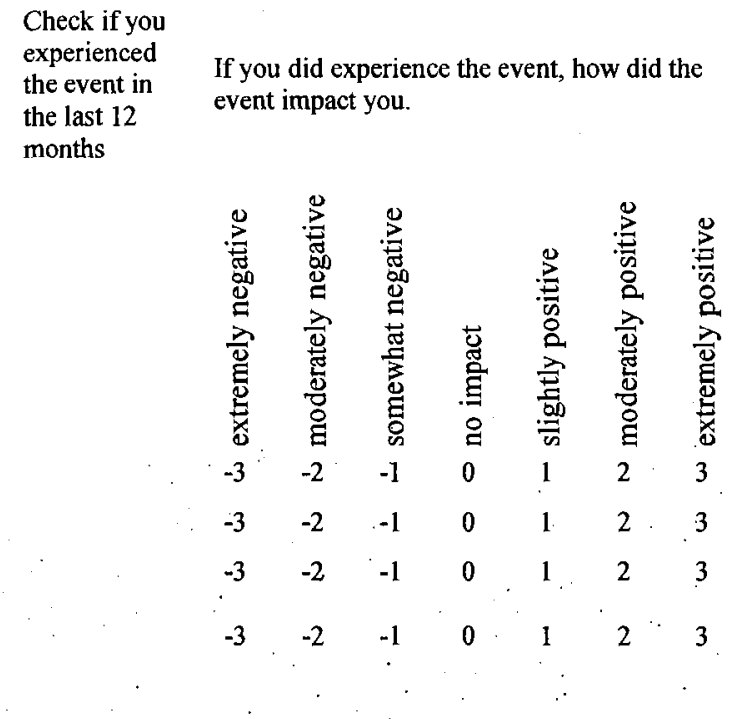


5 Death of a close family member

Major change in eating habits (much more or much less food intake)

7 Foreclosure of mortgage or loan

8 Death of a close friend

9 Minor law violations (traffic tickets, disturbing the peace etc)

10 Wife. girlfriend pregnancy

11 Getting pregnant

12 Changed work situation (different work responsibility, major change in working hours etc)

13 New Job

14 Serious illness or injury of close family member

15 Sexual difficulties

16

Trouble with employer (danger of losing job, being suspended, demoted etc)

17 Trouble with in-laws

Major change in financial status (a lot better off or a lot worse off) - Financial Problems

Major change in closeness of family members

(increased or decreased closeness)

Gaining a new family member (through birth, adoption, family member moving in, etc) Change of residence visiting (increased or decreased participation)

Major change in living conditions of family (building a

32 new home, remodeling, deterioration of home, neighborhood, etc)

33 Divorce
Serious illness or injury of close friend

Retirement from work

Son or daughter leaving home (due to marriage, college etc)

Ending of formal school

Time away from spouse (due to work travel, etc)

Engagement

Breaking up with boyfriend/girlfriend

\begin{tabular}{|c|c|c|c|c|c|}
\hline-3 & -2 & -1 & 0 & 1 & 2 \\
\hline-3 & -2 & -1 & 0 & 1 & 2 \\
\hline-3 & -2 & -1 & 0 & 1 & 2 \\
\hline-3 & -2 & -1 & 0 & 1 & 2 \\
\hline-3 & -2 & -1 & 0 & 1 & 2 \\
\hline-3 & -2 & -1 & 0 & 1 & 2 \\
\hline-3 & -2 & -1 & 0 & 1 & 2 \\
\hline-3 & -2 & -1 & 0 & 1 & 2 \\
\hline-3 & -2 & -1 & 0 & 1 & 2 \\
\hline-3 & -2 & -1 & 0 & 1 & 2 \\
\hline-3 & -2 & -1 & 0 & 1 & 2 \\
\hline-3 & -2 & -1 & 0 & 1 & 2 \\
\hline-3 & -2 & -1 & 0 & 1 & 2 \\
\hline-3 & -2 & -1 & 0 & 1 & 2 \\
\hline-3 & -2 & -1 & 0 & 1 & 2 \\
\hline-3 & -2 & -1 & 0 & 1 & 2 \\
\hline-3 & -2 & -1 & 0 & 1 & 2 \\
\hline-3 & -2 & -1 & 0 & 1 & 2 \\
\hline-3 & -2 & -1 & 0 & 1 & 2 \\
\hline-3 & -2 & -1 & 0 & 1 & 2 \\
\hline-3 & -2 & -1 & 0 & 1 & 2 \\
\hline-3 & -2 & -1 & 0 & 1 & 2 \\
\hline-3 & -2 & -1 & 0 & 1 & 2 \\
\hline-3 & -2 & -1 & 0 & 1 & 2 \\
\hline-3 & -2 & -1 & 0 & 1 & 2 \\
\hline-3 & -2 & -1 & 0 & 1 & 2 \\
\hline-3 & -2 & -1 & 0 & 1 & 2 \\
\hline-3 & -2 & -1 & 0 & 1 & 2 \\
\hline-3 & -2 & -1 & 0 & 1 & 2 \\
\hline-3 & -2 & -1 & 0 & 1 & 2 \\
\hline-3 & -2 & -1 & 0 & 1 & 2 \\
\hline-3 & -2 & -1 & 0 & 1 & 2 \\
\hline-3 & -2 & -1 & 0 & 1 & 2 \\
\hline-3 & -2 & -1 & 0 & 1 & 2 \\
\hline-3 & -2 & -1 & 0 & 1 & 2 \\
\hline-3 & -2 & -1 & 0 & 1 & 2 \\
\hline
\end{tabular}


41 Outstanding personal achievement

$\begin{array}{lllllll}-3 & -2 & -1 & 0 & 1 & 2 & 3\end{array}$

42 Leaving home for the first time

43 Reconciliation with boyfriend/girlfriend

$\begin{array}{lllllll}-3 & -2 & -1 & 0 & 1 & 2 & 3\end{array}$

\section{2) DEMOGRAPHICS :}

1. Year of birth:

2. Sex : Male/ Female

3. Which group does your annual household income fall into?

1. Less than $\$ 25,000$ per year

4. What best describes your level of education?

2. $\$ 25,000-\$ 49,999$ per year

3. $\$ 50,000-\$ 74,999$ per year

4. $\$ 75,000-\$ 99,999$ per year

5. $\$ 100,000-\$ 149,999$

6. $\$ 150,000-\$ 199,999$

7. Over $\$ 200,000$ per year

1. Some school

2. High school completed

3. Some college

4. College graduate

5. Some post graduate

6. Post graduate completed

7. Some doctoral

8. Doctorate completed

5. Please check the one you feel best describes your racial background:

_African American _Caucasian _ Hispanic _ Native-American _ Other




\section{APPENDIX B \\ LIST OF DELETED SCALE ITEMS}

\section{Intention to Donate Scale}

I will recommend the charity to others for donation

\section{Commitment Scale}

I care about the long term success of this charitable organization

\section{Emotional Utility Scale}

I often give to this charitable organization because I would feel guilty if I didn't

If I never gave to this charitable organization I would feel bad about myself

\section{Personal Nostalgia Scale}

\section{Family}

Not having to worry

Places

Friends

\section{Recovery from Grief scale}

How often thinking about your late close relative/friend make you feel sad?

When you think about your late friend/ close relative how sad do you feel?

\section{Loneliness Scale}

I feel in tune with people around me

I do not feel alone

I have a lot in common with the people around me

I am an outgoing person

There are people I feel close to

I feel left out

I feel isolated from others

I can find companionship when I want it

There are people who really understand me

There are people I can talk to

There are people I can turn to 


\section{VITA}

\section{ALTAF MERCHANT}

7211 Newport Ave, E-mail: amerchan@odu.edu Apt 4, Norfolk, Tel: 7573257210

VA 23505,USA

\section{EDUCATION}

Doctoral Candidate in Marketing, Old Dominion University, Norfolk, USA

Masters in Management Studies (Marketing), K.J.Somaiya Instititute of Management Studies, University of Mumbai (1997)

Bachelor of Commerce, Sydenham College, University of Mumbai (1993)

\section{RESEARCH}

Research Areas- Nostalgia, Time Orientation, Consumer Innovativeness, Charitable Giving, Cross-cultural

\section{Journal Publications}

Ford, John B. and Altaf Merchant, "A Ten-Year Retrospective Of Advertising Research Productivity: 1997-2006," accepted for publication by the Journal of Advertising.

Merchant, Altaf and John B. Ford (2008), "Nostalgia and Giving to Charity: A Conceptual Framework for Discussion and Research," International Journal of Nonprofit and Voluntary Sector Marketing ${ }_{2} 13$ (1), 13-30.

\section{Conference Proceedings}

Merchant, Altaf and John Ford (2008), "How Personal Nostalgia Influences Giving To Charity: A Research Proposal," accepted for publication at the American Marketing Association Summer Educator's Conference (Abstract)

Merchant, Altaf (2008), "How Personal Nostalgia Influences Giving To Charity," Proceedings of Academy of Marketing Science Annual Conference , 31, 219 (Abstract)

Merchant, Altaf and Kiran Karande (2007), "Does Time Orientation Influence Consumer Innovativeness?: Going Beyond Nostalgia," Proceedings of the American Marketing Association Summer Educators Conference, 18, $92-93$ (Abstract). This paper was presented by me at the conference. 
Merchant, Altaf, John Ford and Mahesh Gopinath (2007), "Measuring the Intensity of the Personal Nostalgia Experience," Proceedings of the Society for Marketing Advances Conference, 48-49_(Abstract). This paper was presented by me at the conference.

Merchant, Altaf, John Ford and Mahesh Gopinath (2007), "How the emotions of personal nostalgia influence giving to charity: A Research Agenda," Proceedings of the International Colloquium on Non Profit, Social and Arts Marketing, 6, 55-59 (Abstract). This paper was presented by me at the conference.

Theresa Kirchner, John Ford and Altaf Merchant (2007), "Coopetition In The Non Profits Arts Sector," Proceedings of the International Conference on Arts and Cultural Management, 9, 36-37

Poster Presentations

"Nostalgia and Giving to Charity" at the Old Dominion University Research Exposition, $\underline{2007}$

"Does Time Orientation Influence Consumer Innovativeness?: Going Beyond Nostalgia" at the Old Dominion University Research Exposition, 2007

"How Personal Nostalgia Influences Giving To Charity" at the at the Virginia Council of Graduate Schools' Graduate Research Forum, 2008

Research Grants Received

2008 Old Dominion University- College of Business and Public Administration research grant for $\$ 3500$

2008 Old Dominion University- College of Business and Public Administration dissertation research grant for $\$ 2,000$

2007 Old Dominion University- College of Business and Public Administration research grant for $\$ 2,000$

\section{TEACHING}

\section{Teaching Philosophy}

As a teacher I see my role as a catalyst. This entails enabling the students to appreciate marketing, and more importantly igniting their minds to think critically about marketing issues and the application of the theories they have learnt. I believe this would help prepare them for the professional world.

Teaching Experience 
Principles of Marketing (Summer 06, Summer 07)

International Marketing (Spring 07)

Consumer Behavior (Fall 07, Spring 08, Summer 08)

Retail Marketing (Summer 07, Fall 07, Summer 08)

New portals to appreciating our environment (inter disciplinary) (Fall 06)

Teaching Workshops Attended

Virginia Tidewater Consortium's Summer Institute on College Teaching, 2006

\section{BUSINESS EXPERIENCE}

I have seven years experience in brand management, across different consumer product categories - home care, OTC healthcare, foods, oral care. I also have experience in leading cross functional, transnational teams to develop and drive innovations.

Ranbaxy Laboratories Ltd. (2004-2005)

Sr.Manager-Innovations (Global Consumer Healthcare)

Glaxo Smithkline Consumer Healthcare (India) Ltd. (2001-2004)

Marketing Manager: Nutritional Food Services Division (2003-2004)

Group Product Manager: Horlicks (health food drink for kids) (2002-2003)

Group Product Manager: Aquafresh Toothpaste (2001-2002)

Reckitt Benckiser India Ltd. (1999-2001)

Brand Manager (Innovations): Dettol (antiseptic soaps) (2000-2001)

Brand Manager: Disprin (analgesics) (1999-2000)

Godrej-Sara Lee Ltd. (1997-1999)

Brand Manager - HIT (household insecticides)

\section{SERVICE}

To students and the University

Representative of the Business PHD program on the Deans Student Advisory

Committee of the College of Business and Public Administration, Old Dominion

University, 2006-07

Member of the Deans Committee for developing a Student Code of Conduct for College of Business and Public Administration, Old Dominion University, 2007

To the academic discipline 
Reviewer for the International Journal of Nonprofit and Voluntary Sector Marketing, 2008

Reviewer for the World Social Marketing Conference, 2008

Reviewer for the Academy of Marketing Conference, 2008

Reviewer for the American Marketing Association Summer Educator's Conference, 2008

Reviewer for the Academy of Marketing Science Review - Special issue on cross-cultural issues in marketing research, 2007

Reviewer for Academy of Marketing Science Doctoral Colloquium, 2007

Reviewer for the International Society of Marketing and Development and the Macro Marketing Society Joint Conference, 2007

Reviewer for the Academy of Marketing Conference, 2007

To the industry

Analyzed the "FISO - Fit In, Stand Out" model for the Leadership for International Finance and Enterprises, LLC (I am featured in the "Mastering the FISO Factor Newsletter", 2008, Volume 4, Issue 1)

Studied the psychographic profile of the donors of WHRO TV Network (Public Broadcasting Services, USA)

\section{ACADEMIC RECOGNITIONS}

Awarded the American Marketing Association Foundation Nonprofit Travel Grant in 2008

Elected to be a member of the Honors Society of Beta Gamma Sigma in 2008

Fellow of the American Marketing Association-Sheth Foundation Doctoral Consortium in 2007

Awarded the "Love of Learning Award" by the Honors Society of Phi Kappa Phi in 2007

Elected to be a member of the Honors Society of Phi Kappa Phi in 2007

Awarded the Outstanding Doctoral Student in Marketing Award by the College of Business and Public Administration of the Old Dominion University in 2007 
Awarded the Marvin and Marilyn Simon Fellows Endowed Scholarship for outstanding academic accomplishment in 2007

Awarded the Old Dominion University Dissertation Fellowship, 2007-08

Awarded Research Assistantship, 2005-2007

Other Recognitions

Awarded the "Glaxo Smithkline Spirit Award for Business Excellence," for my performance as a Brand Manager, 2002

Winner of the Dandekar Trophy of the Bombay Management Association for best paper presentation by a MBA student, 1997

Winner of the Khandelwal Trophy of the Bombay University for best paper presentation by a MBA student, 1996 